UNIVERSIDADE FEDERAL DE JUIZ DE FORA

PROGRAMA DE PÓS-GRADUAÇÃO EM GEOGRAFIA

INSTITUTO DE CIÊNCIAS HUMANAS

LUCAS PINHEIRO DE PAULA

O PROCESSO DE FORMAÇÃO HISTÓRICO-POLÍTICO E TERRITORIAL DO MUNICÍPIO DE VISCONDE DO RIO BRANCO

JUIZ DE FORA

2021 


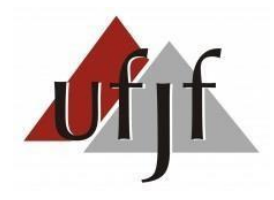

UNIVERSIDADE FEDERAL DE JUIZ DE FORA

PROGRAMA DE PÓS-GRADUAÇÃO EM GEOGRAFIA

INSTITUTO DE CIÊNCIAS HUMANAS

O PROCESSO DE FORMAÇÃO HISTÓRICO-POLÍTICO E TERRITORIAL DO MUNICÍPIO DE VISCONDE DO RIO BRANCO

Dissertação de Mestrado apresentada ao Programa de Pós-Graduação em Geografia da Universidade Federal de Juiz de Fora, como requisito para obtenção do título de Mestre em Geografia. 
DE PAULA, Lucas Pinheiro.

O PROCESSO DE FORMAÇÃO HISTÓRICO-POLÍTICO E TERRITORIAL DO MUNICÍPIO DE VISCONDE DO RIO BRANCO / Lucas Pinheiro de Paula - 2020. $111 p$.

Orientador: Ricardo Tavares Zaidan

Dissertação (mestrado acadêmico) - Universidade Federal de Juiz de Fora, Instituto de Ciências Humanas.

Programa de Pós Graduação em Geografia, 2021. 


\section{O PROCESSO DE FORMAÇÃO HISTÓRICO-POLÍTICO E TERRITORIAL DO MUNICÍPIO DE VISCONDE DO RIO BRANCO}

Dissertação submetida ao Programa de PósGraduação em Geografia da Universidade Federal de Juiz de Fora, como requisito para obtenção do título de Mestre em Geografia.

Aprovada em 16 de março de 2021

\section{BANCA EXAMINADORA}

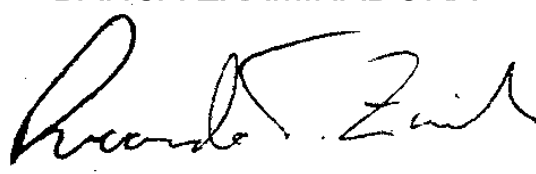

Dr. Ricardo Tavares Zaidan - Orientador

Universidade Federal de Juiz de Fora

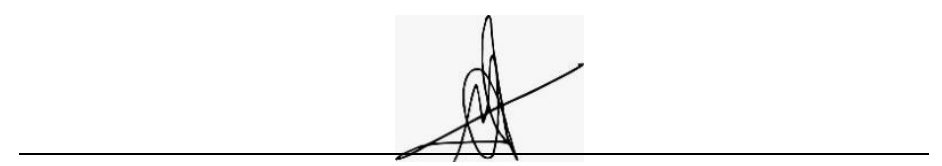

Dr. Angelo Alves Carrara

Universidade Federal de Juiz de Fora

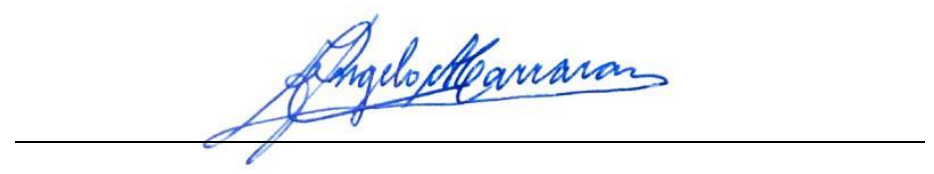

Dr. Manoel do Couto Fernandes

Universidade Federal do Rio de Janeiro 


\section{DEDICATÓRIA}

Dedico este trabalho a todos meus familiares e aqueles que contribuíram e me ajudaram de alguma maneira. 


\section{AGRADECIMENTOS}

Primeiramente gostaria de agradecer aos meus familiares que sempre apoiaram minha caminhada e me incentivaram em todas as decisões que tomei durante meu trajeto até esse momento. Sem esse ambiente familiar de apoio e confiança eu não teria conseguido chegar até aqui. Em especial gostaria de agradecer a minha mãe Edney Aparecida Pinheiro de Paula e ao meu pai João Batista de Paula por serem pessoas incríveis que me auxiliaram em toda minha trajetória. Um agradecimento também para minha irmã Lara Pinheiro de Paula, a maior responsável por proporcionar um ambiente alegre dentro de casa, que foi muito importante, principalmente nesse período de isolamento durante a pandemia. Por fim, gostaria de agradecer aos meus avós por todo o carinho e atenção que sempre tiveram comigo.

Agradeço a minha namorada Lays Kelmer Costa, que além de companheira é uma ótima amiga, e ao longo dessa caminhada esteve sempre ao meu lado. Agradeço também pela paciência de escutar minhas angústias, que em vários momentos se manifestaram mas você me deu forças para prosseguir. Também agradeço pelos bons momentos que tornaram a caminha mais leve.

Quero agradecer ao meu orientador, professor e amigo Ricardo Tavares Zaidan, que esteve ao meu lado não só durante o mestrado mas ao longo de praticamente toda a vida acadêmica, sempre acreditou no meu potencial, me apoiou e ajudou a levantar a cabeça nos momentos mais difíceis. Agradeço por todos os conselhos, que vão muito além da vida acadêmica.

Gostaria de agradecer ao professor e amigo Angelo Alves Carrara, por abrir as portas para a pesquisa na graduação, e ter se mostrado sempre à disposição com conselhos e dicas para me ajudar ao longo dessa trajetória.

Gostaria de agradecer também ao professor Pedro José de Oliveira Machado, que sempre se mostrou a disposição para auxiliar na execução deste trabalho.

Agradeço a todos os colegas do Laboratório de Geoprocessamento Aplicado (LGA), aos demais professores, a secretaria do Programa de Pós-Graduação em Geografia (PPGEO/UFJF) e a Universidade Federal de Juiz de Fora (UFJF) que colaboraram para essa formação acadêmica. 


\section{RESUMO}

O Estado brasileiro enfrentou ao longo do século XIX o desafio de ordenar o território no interior das províncias. A forma como se estabelecia os limites municipais era um problema e o crescimento do número de municípios principalmente a partir da década de 1830 dificultou ainda mais a delimitação da área dos municípios. Junto a essa questão a constituição político-administrativa se apresentava de uma forma muito mais complexa como conhecemos atualmente. Se os municípios atualmente são subdivididos apenas em distritos, anteriormente os poderes políticos, judiciários e eclesiásticos participavam do ordenamento territorial e diferentes categorias se sobrepunham gerando um complexo ordenamento territorial. A cidade de Visconde do Rio Branco, localizada no sudeste de Minas Gerais tem seu processo de formação inserido dentro desse contexto. Quando ainda povoado denominava-se Aldeia do Xopotó dos Coroados, e o município foi criado somente em 1839 após ser desmembrado de Pomba com a denominação de Vila de São João Batista do Presídio. O município do Presídio tem um papel importante na consolidação da territorialidade da porção central da zona da mata mineira, do seu território originaram-se 49 municípios. Nesse sentido o objetivo dessa pesquisa é discutir a evolução políticoadministrativa e territorial a partir da Vila de São João Batista do Presídio, no período de 1839 até os dias atuais. A metodologia adotada fundamentou-se em pesquisas bibliográficas, geoprocessamento aplicado a cartografia histórica e involução cartográfica. Os principais resultados obtidos consistem na representação cartográfica do limite territorial de Visconde do Rio Branco para diferentes períodos e um conhecimento mais detalhado a respeito do ordenamento territorial da área de estudo. Dessa forma, espera-se que a pesquisa possa contribuir com informações e materiais cartográficos que enriqueçam a geografia-histórica do municípios de Visconde do Rio Branco e também dos municípios que se desmembraram de seu território original.

Palavras-chave: Visconde do Rio Branco; ordenamento territorial; município 


\begin{abstract}
The Brazilian State faced throughout the 19th century the challenge of ordering the territory in the interior of the provinces. The way in which the municipal limits were established was a problem and the growth in the number of municipalities, especially from the 1830s onwards, made it even more difficult to define the area of the municipalities. Along with this issue, the political-administrative constitution presented itself in a much more complex way as we know it today. If the municipalities are currently subdivided only into districts, previously political, judicial and ecclesiastical powers participated in the territorial ordering and different categories overlapped, generating a complex territorial ordering. The city of Visconde do Rio Branco, located in the southeast of Minas Gerais has its formation process within this context. When still inhabited, it was called Aldeia do Xopotó dos Coroados, the municipality was created only in 1839 after being separated from Pomba under the name of Vila de São João Batista do Presídio. The municipality of Presídio has an important role in consolidating the territoriality of the central portion of the area of the Minas Gerais forest, from its territory 49 municipalities originated. In this sense, the objective of this research is to discuss the political-administrative and territorial evolution from the Vila de São João Batista do Presídio, from 1839 to the present day. The methodology adopted was based on bibliographic research, geoprocessing applied to historical cartography and cartographic involution. The main results obtained consist of the cartographic representation of the territorial limit of Visconde do Rio Branco for different periods and a more detailed knowledge about the territorial ordering of the study area. In this way, it is hoped that the research can contribute with information and cartographic materials that enrich the historical geography of the municipalities of Visconde do Rio Branco and also of the municipalities that dismembered from ther original territory.
\end{abstract}

Keywords: Visconde do Rio Branco; territory ordinance; county 


\section{LISTA DE FIGURAS}

Figura 1: Fluxograma Metodologia de análise de mapas históricos por

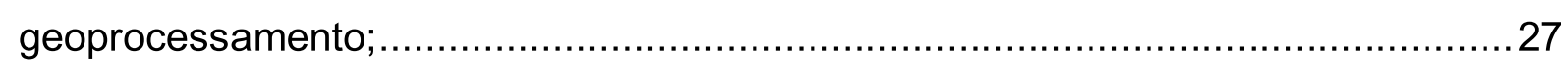

Figura 2: Fluxograma Fases metodológicas para análise de Cartografia Histórica.. 28

Figura 3: Diferentes categorias da história-político administrativa e territorial .........34

Figura 4: Mapa de Rio Branco produzido pela Comissão Mineira do Centenário em 1927 52

Figura 5: Fluxograma dos procedimentos metodológicos 57

Figura 6: Mosaico das cartas topográficas que abarca a área representada pelo mapa antigo. 60

Figura 7: Demarcação do então curato de São Sebastião do Feijão Crú $(A)$ na base cartográfica atual (B). O Curato corresponde atualmente ao município de Leopoldina.

Figura 8: Vetorização do Mapa Topográfico dos Municípios do Presídio, Pomba e São João Nepomuceno. 68

Figura 9:Extensão territorial do município do Presídio em 1847 sobreposto ao ordenamento atual dos municípios; 70

Figura 10: Genealogia a partir da Vila de São João Batista do Presídio. 89

Figura 11: Divisão territorial em 1995. .90

Figura 12: Divisão territorial em 1961 92

Figura 13: Divisão territorial em 1941; .93

Figura 14: Divisão territorial em 1900 .95

Figura 15: Divisão territorial em 1872 97

Figura 16: Divisão territorial em 1839 99

Figura 17: Comparação da divisão política legal com a divisão do IBGE de 1900.103

Figura 18: Comparação da divisão política legal com a divisão do IBGE de 1872.104 


\section{LISTA DE TABELA}

Tabela 1:Glossário com significado das categorias que compõem o ordenamento territorial. Fonte: Elaborado pelo autor a partir das interpretações de Martins e Soares, 2016 35

Tabela 2:Relação das povoações dos Termos de Mariana, Queluz e Barbacena próximas de Visconde do Rio Branco, com declaração do número de fogos em 1830.

Tabela 3: Toponímia e categoria dos pontos demarcados no mapa do Theodoro; .. 66 Tabela 4: Evolução do número de municípios criados a partir do território da Vila de São João Batista do Presídio; 72 


\section{Sumário}

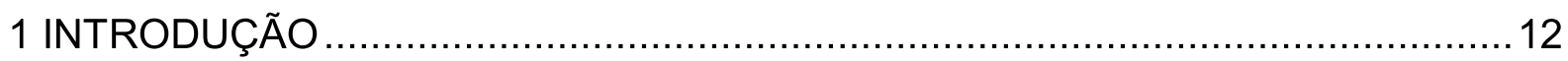

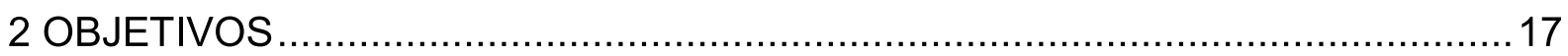

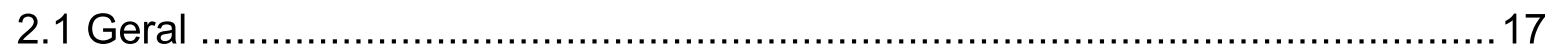

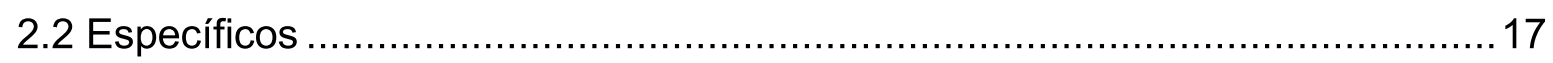

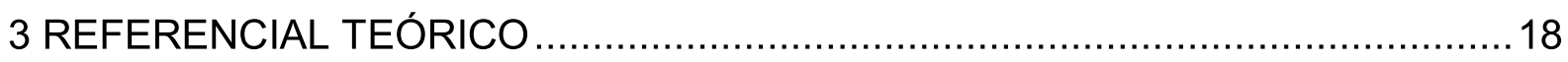

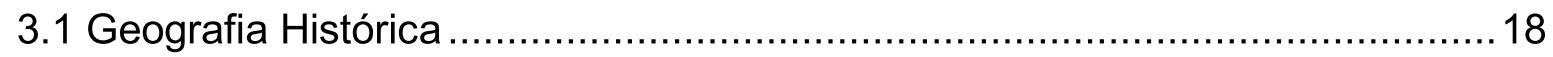

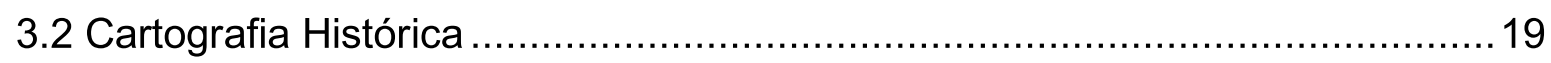

3.3 Geoprocessamento aplicado a Cartografia Histórica .....................................22

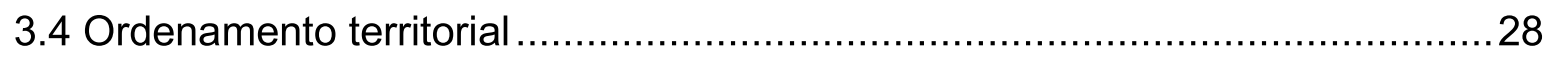

4 AS CATEGORIAS ADMINISTRATIVAS ECLESIÁSTICAS E JUDICIÁRIAS NO ORDENAMENTO DO TERRITÓRIO E A ORGANIZAÇÃO DO TERRITÓRIO A PARTIR DO MAPA HISTÓRICO DE 1847

4.1 As categorias administrativas eclesiásticas e judiciárias no ordenamento do território 33

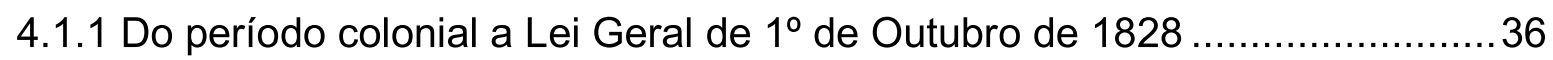

4.1.2 Da Lei Geral de $1^{\circ}$ de Outubro de 1828 até o Brasil República.................... 43

4.1.3 A organização territorial a partir da república .........................................51

4.2 A organização do território da Vila de São João Batista do Presídio a partir do

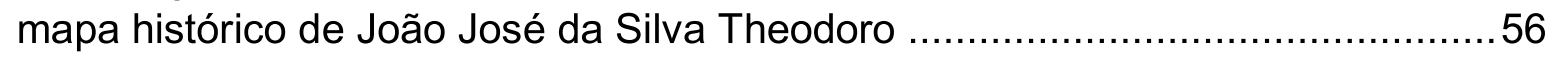

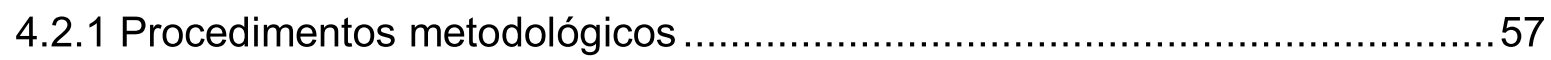

4.2.2 Ordenamento do território a partir da perspectiva de João José da Silva

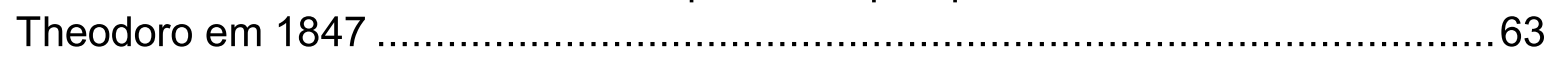

5 A INVOLUÇÃO CARTOGRÁFICA DA VILA DE SÃO JOÃO BATISTA DO PRESÍDIO .71

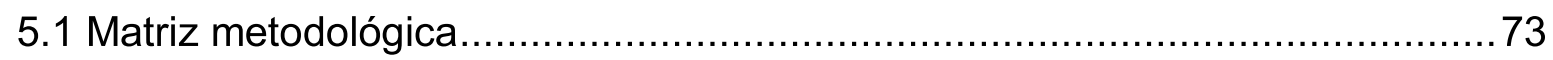

5.2 Evolução política a partir da Vila de São João Batista do Presídio ……….......75

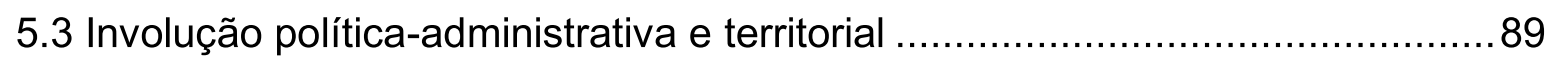

5.4 Comparando a divisão realizada neste trabalho com a divisão realizada pelo IBGE (Instituto Brasileiro de Geografia e Estatística).......................................100

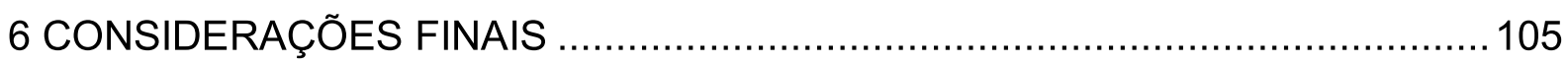

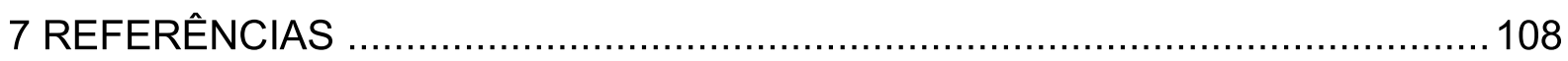




\section{INTRODUÇÃO}

Os limites territoriais se alteram, seja em escala mundial, nacional, ou até mesmo municipal. Essas alterações se encadeiam no tempo através de relações de poder. O estado nacional brasileiro, ao longo dos anos teve a divisão política administrativa de seu território diversas vezes alterada até chegar a sua configuração atual. Por exemplo, em 1853, a Província do Paraná se desmembrou de São Paulo, e mais recentemente em 1975, foi criado o estado de Mato Grosso do Sul (desmembrado do Mato Grosso). Concomitante as alterações em escala nacional, diversas e muito mais intensas foram as alterações em nível municipal. No estado de Minas Gerais, teve-se um aumento significativo do número de municípios, que salta de 72 (segundo o censo de 1872) para 853 (segundo o censo de 2010).

A primeira divisão administrativa no estado de Minas Gerais, ocorreu da criação das três primeiras vilas no ano de 1711 pelo governador Antônio Albuquerque Coelho de Carvalho, sendo elas: Ribeirão do Carmo, atualmente Mariana, Vila Rica, atualmente Ouro Preto e Vila Real de Nossa Senhora da Conceição de Sabará, atualmente Sabará. Os municípios subsequentes que foram criados ao longo dos anos surgiram do desmembramento das primeiras vilas de Minas Gerais (COSTA, 1997).

O aumento no número de municípios ao longo dos anos, segundo Reis et al. (2011), ocorreu devido à expansão das fronteiras econômica e demográfica, pela motivação a descentralização política-administrativa nos períodos de liberalização política, e também foi motivado pela possibilidade de maior arrecadação de impostos através da instalação de novas partições públicas.

Nos dias atuais, os critérios para a criação de um novo município são mais rigorosos. Somente ocorre mediante a estudos de viabilidade municipal, análise do tamanho da população, viabilidade financeira e de infraestrutura, além de plebiscito envolvendo a população dos municípios envolvidos. Os desmembramentos são realizados por lei estadual, dentro de período determinado por lei complementar federal, como encontra definido a partir da Emenda Constitucional n 15 em seu artigo 18 da Constituição Federal. Porém essas definições são recentes, durante o século XIX e até mesmo início do século $X X$, não só os critérios de criação de novos 
municípios eram distintos, como a própria organização do território das províncias se subdividiam em uma extensa e complexa lista de diferentes categorias.

Uma análise da organização do território demonstra que se atualmente a subdivisão do Estado se dá em municípios e distritos, em períodos anteriores a organização se estendia a outras diversas classes de classificação. Durante o século $\mathrm{XIX}$, diversas eram as categorias que demarcavam o território da província, criando uma complexa organização do território que se sobrepunha entre o poder administrativo, eclesiástico e judiciário.

Carrara e Machado (2020) evidenciam que até mesmo o vocábulo município apresentava significado distinto do atual. Ou seja, o município como uma base territorial abrangida pelo poder administrativo da cidade sede somente adquire tal sentido a partir da Lei Geral de $1^{\circ}$ de outubro de 1828 . Portanto, o vocabulário moderno utilizado na divisão territorial do Estado foi alterado ao longo do tempo, até se estabilizar na categoria atual.

Diante do cenário de crescimento do número de municípios, de categorias de organização complexas e critérios indefinidos para a criação de novos municípios, identifica-se um cenário desafiador para o Estado brasileiro principalmente no século XIX na demarcação dos limites territoriais e na organização do território.

Para compreender a organização territorial de determinada área, ou a formação do limite geográfico de determinado município, deve-se realizar uma análise temporal, partindo do tempo decorrido até o atual. Dessa forma, os estudos de organizações territoriais adentram no campo da Geografia Histórica.

A Geografia Histórica estabelece uma relação entre o espaço-tempo, admitindo que muitos processos só podem ser compreendidos através de uma análise que considere o espaço pretérito. Segundo Pires (2008), "pode-se afirmar que a Geografia Histórica estuda as características dos espaços históricos, sua morfologia, paisagem e organização territorial assim como sua formação social."

Por conseguinte, para atingir o objetivo do presente trabalho de discutir a evolução político-administrativa e territorial a partir da Vila de São João Batista do Presídio, será necessário retornar a organização territorial antes mesmo da criação de sua vila em 1839.

A criação da Vila de São João Batista do Presídio se remete ao contexto de ocupação da Zona da Mata. Carneiro e Matos (2010), expõem que em meados do 
século XVIII, desbravadores adentraram por essas terras com a finalidade de introduzir a agropecuária, realizar a extração de minerais e vegetais ou colocar em prática a política de aldeamentos dos índios.

Neste contexto desenvolveu-se o povoado de São João Batista do Presídio. O processo de ocupação do povoado remonta a conflitos com indígenas que viviam nessa região. Com a intenção de solucionar os conflitos, o governador Luiz Diogo Lobo da Silva incentivou a criação de um grande aldeamento (TAVARES, 2013). A consolidação do povoado ocorreu em 1787, com a construção de sua primeira capela e a consagração do povoado em arraial (PINTO, 2002).

A Vila de São João Batista do Presídio e seu respectivo município, foi emancipado de Pomba em 1839, de acordo com a lei provincial $n^{\circ} 134$. Atualmente a vila apresenta topônimo de Visconde de Rio Branco, porém sua antiga extensão territorial ao longo do século XIX e XX sofreu diversas modificações, fruto das mudanças dos limites territoriais e do desmembramento de quarenta e nove municípios a partir de sua área que abarcava toda Zona da Mata mineira central.

Ainda no século XIX, a Vila de Presídio além dos diversos desmembramentos em seu território original para a criação de novos municípios, também passou por um período de supressão e transferência de sede. Sua sede foi suprimida passando a condição de distrito da então vila de São Januário de Ubá em 1853. A mudança de sede alterou a dinâmica de influência na região e iniciou um imbróglio territorial entre São João Batista do Presídio e São Januário de Ubá. Em 1868 a então denominada vila de Ubá foi extinta, e seu território voltou a ser anexado a Vila de Presídio, que nesse período já denominava-se Visconde de Rio Branco, segundo a lei provincial. Posteriormente em 1871, Ubá foi novamente elevada a situação de vila e Visconde de Rio Branco voltou a condição de distrito. Somente no ano de 1881 Visconde do Rio Branco conseguiu se desmembrar e os dois municípios seguiram com suas próprias sedes (FERREIRA, 1959).

A localidade recebeu diferentes nomes ao longo de sua história. Inicialmente foi denominada como Aldeia do Xopotó dos Coroados, em referência aos índios que se localizavam naquela área. No século XIX recebeu o nome de São João Batista do Presídio em referência aos presos políticos e comuns que a localidade recebia. $E$ por fim recebeu o nome de Rio Branco e Visconde do Rio Branco em homenagem a José Maria da Silva Paranhos, o Visconde do Rio Branco. 
Para discutir a evolução político-administrativa e territorial a partir da Vila de São João Batista do Presídio, utiliza-se de pesquisas bibliográficas, destacando o levantamento das leis que estabelecem mudanças político-administrativa e territoriais referentes a área de estudo. Além da fonte textual, mapas históricos apresentam uma possibilidade para a compreensão da organização do território.

O campo de pesquisa que estuda os mapas históricos e antigos denomina-se Cartografia Histórica, e proporciona ao pesquisador o acesso a novas informações além das fontes textuais. Antes de se retirar qualquer informação dos produtos cartográficos históricos, deve-se realizar o tratamento desses mapas, visto que esses foram elaborados utilizando técnicas antigas, o que significa, que esses mapas não apresentam a mesma precisão espacial que os produtos cartográficos atuais.

Nessa perspectiva, o presente trabalho utilizou das interfaces do geoprocessamento, com aplicação de técnicas de georreferenciamento e vetorização como meio para utilização das informações presentes no mapa de João José da Silva Theodoro de 1847. Através do geoprocessamento, foram elaborados mapas temáticos que retratam a evolução histórica da organização territorial na área de estudo.

Propõe-se como período de estudo, a análise temporal da evolução da organização territorial de 1839 até o final de 2020. A data inicial, foi escolhida por se tratar do ano em que a vila de São João Batista do Presídio foi emancipada da vila de Pomba. O maior desafio encontra-se em desvendar a organização políticoadministrativa e territorial no século XIX, isso ocorre devido as alterações recorrentes nos limites entre municípios. E como afirmam Carrara e Machado (2020), até 1938 o território dos municípios mineiros eram demarcados por propriedades rurais.

A justificativa para realizar um estudo da evolução da organização territorial é compreender como sucederam as relações de poder no território ao longo dos anos, para assim explicar a configuração dos limites políticos-administrativos no período de 1839 até o final de 2020.

Esse trabalho pretende também contribuir com informações e materiais cartográficos que enriqueçam a geografia-histórica do municípios de Visconde do Rio Branco, e também dos municípios que se desmembraram de seu território original.

Além disso, para atingir os resultados, será utilizado uma metodologia de associação entre geoprocessamento e cartografia histórica, um campo que abre 
novas possibilidades para fornecer informações a estudos científicos. Através do geoprocessamento, também será pautado mais um ponto de relevância para a pesquisa, que consiste em utilizar desse recurso para que a evolução territorial da área de estudo seja representada em produtos cartográficos, indo além da descrição textual, o que fornece resultados inéditos para compreender a geografia histórica da região.

O estudo da evolução política-administrativa e territorial a partir da Vila de São João Batista do Presídio é de grande importância para a consolidação da territorialidade da porção central da Zona da Mata Mineira. A extensão territorial da antiga vila originou direta ou indiretamente quarenta e nove municípios, portanto a história territorial da vila é também a história de formação do território de um número significativo de municípios da Zona da Mata.

O trabalho foi dividido em diferentes capítulos, além dos objetivos e do referencial teórico.

O quarto capítulo, denominado "As categorias administrativas eclesiásticas e judiciária no ordenamento do território e a organização do território a partir do mapa histórico de 1847", aborda inicialmente os diferentes conceitos administrativos, eclesiásticos e judiciário que se referiam e se referem a organização do território das províncias. O capítulo também consiste em a partir do geoprocessamento aplicado a cartografia histórica, representar a organização espacial da Vila de São João Batista do Presídio em 1847 a partir da interpretação e da descrição geográfica e cartográfica de João José da Silva Theodoro.

O capítulo cinco, intitulado "A involução cartográfica da Vila de São João Batista do Presídio", apresenta um estudo que parte inicialmente da divisão administrativa e dos limites atuais dos municípios e realiza o processo de evolução reversa. Através do processo de involução identifica-se as diferentes divisões administrativas de caráter temporal. As divisões criadas a partir da involução são comparadas com as divisões administrativas do IBGE (Instituto Brasileiro de Geografia e Estatística). 


\section{OBJETIVOS}

\subsection{Geral}

O presente trabalho tem como objetivo discutir a evolução políticoadministrativa e territorial a partir da Vila de São João Batista do Presídio, no período de 1839 até os dias atuais.

\subsection{Específicos}

$\checkmark$ Explicar as definições das categorias do ordenamento territorial usados outrora e atualmente, para designar as subdivisões políticas do Estado;

$\checkmark$ Explicar a história evolutiva de São João Batista do Presídio, da criação do povoado até a consolidação da cidade;

$\checkmark$ Discutir a organização político-administrativa e territorial de acordo com a interpretação da descrição geográfica e cartográfica de João José da Silva Theodoro;

$\checkmark$ Identificar as mudanças de topônimos dos municípios que pertenciam a Vila de São João Batista do Presídio;

$\checkmark$ Realizar um estudo de involução político-administrativo e territorial, partindo da atualidade até o ano de criação da Vila de São João Batista do Presídio em 1839;

$\checkmark$ Comparar a divisão histórica dos limites municipais gerados a partir do estudo involutivo com a demarcação oficial posta pelo IBGE (Instituto Brasileiro de Geografia e Estatística); 


\section{REFERENCIAL TEÓRICO}

O presente capítulo tem a finalidade de abordar os conceitos alinhados com o trabalho e a sua temática. Busca também demonstrar outros trabalhos já realizados sobre o assunto. Nessa perspectiva, este texto trata principalmente da temática de Cartografia Histórica e ordenamento territorial. Também destacam-se as práticas de geoprocessamento alinhadas a Cartografia Histórica, demonstrando obras de outros autores.

\subsection{Geografia Histórica}

Durante o século XX, a Geografia passou por movimentos de renovação do pensamento geográfico. Junto com o movimento de ascensão da Nova Geografia na década de 50, surge também o movimento de ascensão da Geografia Histórica e Cultural e subsequentemente à década de 70 surge o movimento que dá origem a corrente da Geografia Radical ou Crítica. Apesar de muitas vezes ser negligenciada nos estudos de evolução do pensamento geográfico, a ascensão da Geografia Histórica e Cultural ocorreu a partir da revalorização da história nos estudos geográficos (PIRES, 2008).

A Geografia Histórica em seu trajeto trata-se de um campo pouco difundido e as vezes deixada de lado pelos geógrafos. Por um longo período foi avaliada como uma disciplina autônoma da história e também como um campo da antropologia. Esse marasmo fez com que a Geografia Histórica fosse por vezes confundida com a história da geografia como se fossem sinônimos. Apesar disso, diversos são os trabalhos de geografia que se atentam ao tempo pretérito, como por exemplo as pesquisas de análise ambiental que retratam a evolução do uso do solo ao longo do tempo (ERTHAL, 2003).

A Geografia e a História são duas ciências que possuem uma estreita relação. É imprescindível para a História espacializar os fenômenos temporais, como também é necessário entender o meio geográfico e o espaço físico para conseguir narrar determinado fato histórico. Para a Geografia, sendo seu objeto de estudo o espaço geográfico, e tendo o conhecimento que esse espaço geográfico se altera no tempo, 
obrigatoriamente espaço-tempo deve ser tratado como uma unidade pela ciência geográfica.

O geógrafo ao se empenhar nos estudos dos fenômenos ambientais e sociais, não deve esquecer que se tratam de fenômenos também temporais, logo a Geografia Histórica deve ser considerada como um ramo importante não só para compreender o espaço pretérito, mas também para explicar os processos de produção espacial que ocorrem no presente (BARBOSA, 2017).

Portanto, a Geografia Histórica, estabelece uma relação entre o espaço-tempo, admitindo que muitos processos só podem ser compreendidos através de uma análise que considere o espaço pretérito. Segundo Pires (2008), "pode-se afirmar que a Geografia Histórica estuda as características dos espaços históricos, sua morfologia, paisagem e organização territorial assim como sua formação social."

\subsection{Cartografia Histórica}

Para compreender o campo da Cartografia Histórica, antes se faz necessário tomar conhecimento da Cartografia. Nos dicionários de língua portuguesa, é apresentada como a arte de produzir ou gerar mapas e cartas. Etimologicamente, cartografia é uma palavra derivada do grego "graphein" e do latim "charta" que significam respectivamente escrita e papel. Esses significados representam superficialmente o que é cartografia, para chegar em um conceito já ocorreram diversas tentativas de defini-la. Dentre as definições cabe destacar a desenvolvida por Taylor em 1991 e apropriada pela Associação Cartográfica Internacional (ICA):

ciência que trata da organização, apresentação, comunicação e utilização da geoinformação, sob uma forma que pode ser visual, numérica ou tátil, incluindo todos os processos de elaboração, após a preparação dos dados, bem como o estudo e utilização dos mapas ou meios de representação em todas as suas formas. (TAYLOR, 1991).

No campo da cartografia, os pesquisadores viram uma nova possibilidade de realizar diversos trabalhos e estudos com os mapas históricos, contribuindo de forma direta para um impulso no que se refere ao desenvolvimento de um de seus diversos ramos, a Cartografia Histórica. Rossato (2006) a define como:

Uma especialidade da Cartografia que tem como enfoque as características temporais das representações cartográficas, assim como seu estudo, construção e utilização, e complementa que 
trabalhos que 'utilizam mapas antigos e/ou históricos como fontes de informações' e/ou 'constroem mapas históricos'. (ROSSATO, 2006 apud MARTINS; SILVA, 2014, p. 493).

A Cartografia Histórica, possibilita trabalhar com diversas fontes de dados históricos, fontes que muitas vezes só se encontram em produtos cartográficos. Nessa perspectiva, a Cartografia Histórica irá fomentar com dados e informações principalmente os estudos dentro do campo da Geografia Histórica. Como já mostrado neste texto, a Geografia Histórica admite o tempo como importante modificador do espaço. E os estudos dos mapas históricos podem permitir a compreensão do espaço pretérito, e consequentemente ajudar a desvendar a produção do espaço atual.

Os estudos que se adentram pelo campo da Cartografia Histórica, muitas das vezes corroboram para uma desordem entre a Cartografia Histórica e a História da Cartografia, fato também relatado com o campo da Geografia Histórica. Tal confusão se dá pelo fato da falta de conceitos definidos e pelo interesse por esse campo ainda ser recente no Brasil. Segundo Correa (2008), a História da Cartografia desvenda as técnicas, processos, ferramentas que foram utilizadas ao decorrer do tempo, tratando assim da evolução da cartografia até chegar no contexto atual. Enquanto a Cartografia Histórica trabalha com os mapas datados de anos ou séculos atrás, visando utilizar suas informações.

No Brasil, os estudos relacionados a Cartografia Histórica se intensificam em 1970, devido as publicações realizadas sobre as viagens de Auguste de Saint-Hilaire, os estudos de Raimundo José da Cunha Matos e de Diogo de Vasconcelos, e também pela publicação da primeira edição do Dicionário Histórico-Geográfico de Minas Gerais (BARBOSA, 1995 apud CASTRO, 2017).

Durante a década de 90, ocorreram estudos de Cartografia Histórica aplicados com a finalidade de destacar a história de Minas Gerais. Foram utilizados relatos de viajantes, mapas históricos e diversas fontes de pesquisa. Nessa perspectiva cabe destacar o trabalho de José Joaquim da Rocha (1995), que produziu um vasto material destacando informações da capitania de Minas Gerais. Também nessa década outros estudos foram desenvolvidos, como a publicação "As denominações urbanas de Minas Gerais", que serviram como fonte para diversas pesquisas atreladas a atualização de topônimos de vilas e cidades mineiras (CASTRO, 2017). 
Nos anos 2000, com o aumento da publicação de relatos de viajantes, inicia-se no Brasil o surgimento de grupos de pesquisas em universidades, aumentando os periódicos voltados a Cartografia Histórica, e crescendo também o número de mapas históricos digitalizados. Com o passar dos anos, o Brasil começa a apresentar um acervo de mapas históricos virtuais, algo que já era muito comum em países como Portugal e Espanha, assim os mapas históricos passam a ficar disponíveis não só para pesquisadores, mas também para sociedade (CASTRO, 2017).

Alguns estudos mostram que os mapas surgiram antes mesmo da escrita, e que diversos povos que existiam há milhares de anos já utilizavam desse recurso. Segundo Silva (2003), o mapa denominado de Ga-Sur é o mais antigo que se tem notícia, foi datado a aproximadamente 2400 a 2200 a.C., e foi realizado para solucionar problemas militares na Babilônia, mais especificamente em um vale do rio Eufrates. Obviamente os mapas desse período não apresentavam muitas semelhanças com os que conhecemos atualmente, tendo em vista todo desenvolvimento da cartografia ao longo dos anos. É nessa perspectiva que a Cartografia Histórica contribui para a interpretação e utilização de dados dos mapas.

Os mapas, são o que podemos chamar de produto da cartografia, de uma forma geral são representações gráficas da superfície da Terra. O mapa é uma linguagem e um meio de comunicação que busca transmitir informações que foram construídas pelo cartógrafo para ser interpretada pelo usuário. Logo, se a comunicação é bem sucedida o objetivo daquele mapa foi alcançado, independente do seu período de construção.

Atualmente, para ser considerado mapa são necessárias algumas informações essenciais, como a escala, sistema de projeção, indicação do norte, coordenadas geográficas referenciadas, entre outros. Porém os mapas de antigamente não continham todos esses elementos, e isso não era um empecilho para que fossem classificados como mapas. De fato, o grau de acurácia dos mapas de antigamente tem uma discrepância com a possível acurácia de se atingir atualmente, porém suas informações são valiosas e demonstram a importância de utilizar do campo da Cartografia Histórica para sanar ao máximo as distorções desses mapas de antigamente e utiliza-los como uma importante fonte de informações (CORREA, 2008). 
$\mathrm{Na}$ Cartografia Histórica, se discute a conceituação de mapa antigo e histórico. No presente texto, baseado nas definições de Correa (2008), considera-se o mapa antigo como aquele produzido em tempos remotos, sendo esse tempo relativo, podendo um mapa de 1970 por exemplo ser considerado antigo, desde que ele sofra atualizações constantes. Já o mapa histórico, pode se tratar de um documento atual que representa algum fenômeno histórico, ou um documento original histórico, elaborado com as técnicas cartográficas da época em que foi reproduzido. Nessa perspectiva o mapa de João José da Silva Theodoro de 1847, que será utilizado no trabalho é considerado como um mapa histórico, tendo em vista o fato de sua produção ter se dado com as técnicas cartográficas da época em que foi reproduzido.

Os mapas históricos produzidos com as técnicas existentes de seu tempo em que foram elaborados, não apresentam a mesma exatidão que os mapas produzidos atualmente. Isso se deve a evolução das técnicas de cartografia e do advento dos recursos computacionais que foram englobados na cartografia.

Os trabalhos com mapas históricos apresentam grandes dificuldades, visto que mesmo com o desenvolvimento da cartografia, ainda não se tinha o mesmo rigor dos detalhes como atualmente, a escala do mapa muitas vezes não era homogênea, sendo necessário um trabalho de georreferenciamento árduo. Outro fator são os topônimos, haja vista que muitos rios e serras trocaram de nomes, ou até mesmo fazendas e registros que aparecem nos mapas históricos de tempos remotos e não estão presentes nos atuais (BARROS; COLAVITE, 2009).

Apesar da dificuldade de trabalhar com mapas históricos, a Cartografia Histórica recebe um grande aliado para auxiliar nessa dificuldade que é o geoprocessamento. Este disponibiliza uma gama de recursos para o pesquisador trabalhar com os mapas históricos.

\subsection{Geoprocessamento aplicado a Cartografia Histórica}

O desenvolvimento recente nas últimas décadas da informática, possibilitou com que o geoprocessamento se afirmasse como um importante instrumento para estudos e trabalhos voltados a análise espacial. A sua possibilidade de manipular diversas informações localizáveis no espaço possibilitou estudos em diversas áreas 
científicas, como na Geografia. Segundo, Zaidan (2017), o geoprocessamento se define como:

[...]um ramo de atividades, e pode ser definido como o conjunto de técnicas e métodos teóricos e computacionais relacionados com a coleta, entrada, armazenamento, tratamento e processamento de dados, a fim de gerar novos dados e ou informações espaciais ou georreferenciadas. É importante observar que informações georreferenciadas têm como característica principal o atributo de localização, ou seja, estão ligadas a uma posição específica do globo terrestre por meio de suas coordenadas. (ZAIDAN, 2017, p. 198).

O geoprocessamento começa a ser difundido no Brasil na década de 80 . E atuando em consonância com outra geotecnologia, o SIG (Sistema de Informações Geográficas), se permite uma nova gama de trabalhos utilizando esses recursos. A possibilidade de trabalhar com uma interface amigável e uma base de dados integrada e georreferenciada abriu um leque para a utilização do geoprocessamento nas áreas de planejamento urbano, energia, economia, ambiental e saúde pública.

Apesar da utilização do geoprocessamento no Brasil já ocorrer há algumas décadas, o uso dessa tecnologia na área da Cartografia Histórica é recente. Podendo destacar os trabalhos de Castro, Umbelino e Antunes, Menezes e de Santos, realizados já no século XXI. Cabe destacar também a abordagem deste tema em alguns congressos de cartografia, como o XXIII Congresso Brasileiro de Cartografia e o II Simpósio Luso-Brasileiro de Cartografia Histórica (UMBELINO et al., 2009).

O crescimento do geoprocessamento em associação com os SIG's na Cartografia Histórica, gerou uma nova terminologia para os sistemas de informações voltados à essa temática, denominado de Historical Geographical Information Systems (HGIS). O HGIS em seu cerne se diferencia do SIG por focar principalmente na utilização de dados passados, mas essa nomenclatura não é usual nos trabalhos realizados no Brasil, fato que resulta em uma má definição/tradução do termo HGIS. Nos países da Europa Ocidental e América do Norte, tal temática já está mais difundida, e é onde se desenvolvem os principais HGIS. Mas é válido ressaltar que mesmo se tratando de uma temática pouco discutida no Brasil, já existe um HGIS desenvolvido pela Universidade de Brasília, denominado de Atlas Digital da América Lusa, que busca produzir mapas e dados antigos do período de 1500 a 1800 (MARTINS e SILVA, 2014). 
Entre os trabalhos que alinham Cartografia Histórica e Geoprocessamento, destacam-se no Brasil a comparação de mapas históricos com os atuais, para verificar as distorções presentes referentes as projeções espaciais. Dessa forma podem auxiliar os pesquisadores a identificarem os erros contidos nos mapas produzidos em tempos remotos. Também através do geoprocessamento existem trabalhos que buscam recriar mapas históricos com as tecnologias atuais, ou modificá-los de acordo com objetivo do pesquisador. E por fim, o uso do geoprocessamento permite que vários pesquisadores utilizem dos mapas históricos para vetorizar distintas informações e assim construir uma robusta base de dados.

Atualmente, existem vários softwares que avaliam a precisão dos mapas antigos através das técnicas de cartometria. No presente texto abordou-se sobre o software MapAnalyst, desenvolvido por Bernhard Jenny e Adrian Weber (Instituto de Cartografia, ETH Zurique) que se encontra disponível na internet gratuitamente. Em seu próprio domínio na internet, o software é descrito como: "MapAnalyst é um software para a análise de precisão de mapas antigos. O objetivo principal é calcular as redes de distorção e outros tipos de visualizações que ilustram a precisão geométrica e a distorção de mapas antigos". Tal método de trabalho, foi realizado pela primeira vez por Tobler (1966, apud CASTRO, 2017 p.32) "que calculou os desvios de projeção do mapa de Hereford (1283) em relação ao atual".

Como a maioria dos softwares disponíveis para avaliar a precisão de mapas históricos, o MapAnalyst trabalha com a utilização de dois pontos correspondentes, de mesma localização espacial, onde o primeiro ponto é feito em um mapa antigo, possivelmente impreciso, e o outro ponto em um mapa atual, compartilhando o mesmo sistema de coordenadas. Após a demarcação de vários pontos correspondentes, o software avalia a precisão do mapa antigo através dos vetores de deslocamentos e da distorção da grade de coordenadas. Após a demarcação de diversos pontos correspondentes, o software gera a grade de distorção, que se trata de um método compreensível para visualizar a precisão do mapa antigo. Os locais onde as células da grade encontram-se comprimidas ou ampliadas refletem as maiores distorções locais apresentadas no mapa histórico. Se o mapa histórico não apresentasse distorção, as células de grade gerada seriam perfeitamente regulares.

Além da grade de distorção, o software gera também os vetores de deslocamento, responsável por representar graficamente a precisão de cada par de 
pontos. Os vetores de deslocamento consistem em linhas, que se iniciam no ponto demarcado no mapa antigo, e terminam na localização em que o ponto deveria se encontrar caso o mapa antigo fosse preciso. Assim, quanto mais extenso for as linhas dos vetores gerados, implica nos maiores erros de posicionamento dos pontos demarcados.

O software com base nos pontos vinculados realiza um cálculo geométrico gerando a escala em que se encontra o mapa histórico, e a rotação em graus que o mapa apresenta. Como os mapas históricos apresentam uma variação de escala local, é possível gerar linhas que mostram as variações de escala decorrentes em diversas localidades do mapa.

Diante da apresentação do funcionamento e dos resultados de análise de distorção que o software consegue gerar. Busca-se demonstrar também como o MapAnalyst está sendo utilizado no campo da Cartografia Histórica. O uso do software vai além da verificação das distorções do mapa, como demonstrado por Dutenkefer (2016), em sua metodologia de georreferenciamento relativo.

O georreferenciamento relativo de mapas históricos busca relacionar as feições desses com mapas contemporâneos, dessa forma é possível chegar a um bom nível de exatidão sem distorcer as formas e a representação do mapa histórico. Além disso, - georreferenciamento absoluto estabelece dificuldades, tendo em vista que estabelecer coordenadas cartesianas em mapas que são de um período em que não existiam essa técnica pode ser um problema. Dessa forma Dutenketer (2016) levanta o seguinte questionamento:

Como estabelecer coordenadas cartesianas em mapas que são de épocas em que não havia essa técnica? $\mathrm{E}$, em momentos em que já existia alguma técnica, como estabelecer relações recíprocas com os nossos sistemas de referência contemporâneos sem que suas formas originais fiquem demasiadamente distorcidas? Estamos preocupados com a precisão matemática das localizações espaciais contemporâneas ou com a "precisão" que a cultura da época propiciou na elaboração do mapa? (DUTENKETER, 2016, p. 60).

Nessa perspectiva, o autor desenvolveu a seguinte proposta metodológica: inicialmente, através do software MapAnalyst, selecionou pontos conhecidos do mapa "Nova Lusitânia" do século XVIII e gerou os vetores de deslocamento (como explicado nesse texto, os vetores de deslocamento demonstram o deslocamento que aquele ponto em específico sofreu, logo gera uma projeção de onde ele deveria estar 
localizado caso o mapa histórico não tivesse distorções espaciais). Posteriormente, o autor realizou o georreferenciamento do mapa histórico do século XVIII, para isso utilizou um mapa atual da mesma área geográfica e de coordenadas conhecidas para servir de base para o mapa histórico (nesse tipo de georreferenciamento buscam-se pontos incomuns entre o mapa atual e o histórico). Porém, para um melhor resultado no georreferenciamento, optou-se por marcar os pontos considerando a projeção do deslocamento que o MapAnalyst gerou através dos vetores de deslocamento. Dessa forma, o ponto de controle marcado para realizar o georreferenciamento já considera o quanto foi deslocado.

O geoprocessamento alinhado a Cartografia Histórica tem proporcionado também aplicações na reconstrução de caminhos antigos. O trabalho de Colavite e Barros (2009), realizou a demarcação do Caminho de Peabiru, que se trata de uma rota pré-colombiana que atravessava o estado Paranaense e teve importante participação na construção do estado. Para realizar a demarcação do caminho, os autores utilizaram o mapa antigo de 1952, elaborado por Reihnard Maack. O objetivo do trabalho foi espacializar o Caminho do Peabiru em um mapa atual. Para isso, através do geoprocessamento o mapa de 1952 foi sobreposto sobre um mapa atual de mesma área, foram realizados ajustes na escala do mapa antigo, e através desse processamento de dados obtiveram uma base inicial para dar prosseguimento a demarcação do Caminho.

No campo da Cartografia Histórica, destacam-se também os trabalhos desenvolvidos por José Flávio Morais Castro, que tem publicado diversos artigos e livros que demonstram trabalhos realizados que são frutos do processamento de dados oriundos de mapas históricos. O autor desenvolveu uma metodologia para responder questionamentos que surgem nos trabalhos com mapas históricos, como: data do mapeamento, nome do autor, técnicas empregadas, desvios entre outras questões. Diante dessa perspectiva, Castro (2014), desenvolveu um procedimento metodológico dividido em três etapas: "inventário de fontes" - catalogar, digitalizar e etc; "processo" - representação, análise dos mapas e textos; "produto" georreferenciar, vetorizar e tratar as informações espaciais. 
Figura 1: Fluxograma Metodologia de análise de mapas históricos por geoprocessamento;

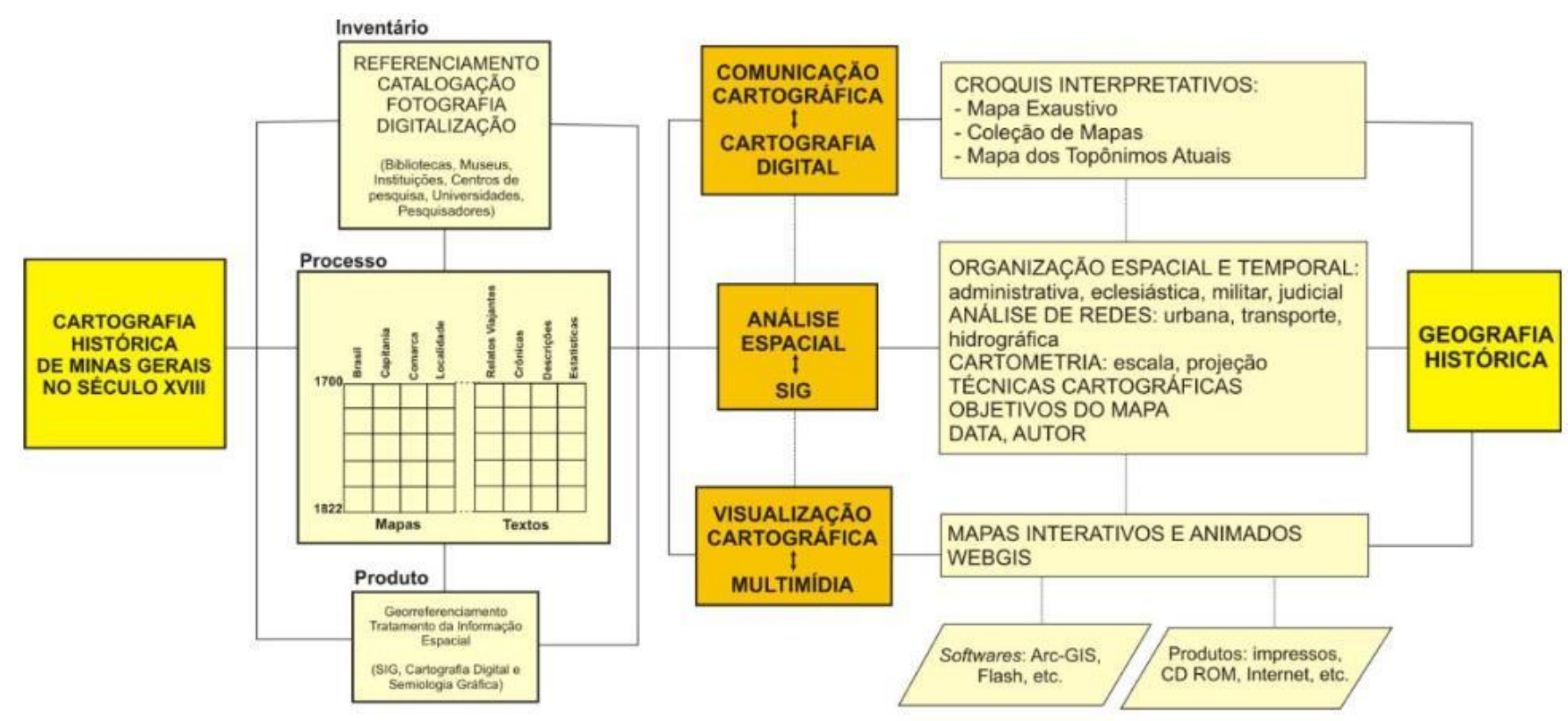

Fonte: Castro (2014).

Por fim, dentre os estudos que buscam associar cartografia histórica e geoprocessamento, destaca-se a tese desenvolvida por Douglas Corbari Corrêa, nomeada Cartografia Histórica do Rio de Janeiro: Reconstituição Espaço-Temporal do Centro da Cidade. Em seu trabalho, publicado no ano de 2008, Corrêa, com o objetivo de comparar o centro da cidade do Rio de Janeiro em 1700 e 2000, utilizouse mapas que representavam a sua área de estudo dentro do seu período histórico.

Através do fluxograma (figura 2), é possível sintetizar como se deu o processo metodológico realizado por Corrêa. Inicialmente, o autor definiu o recorte temporal de seu trabalho e fez um levantamento de todos os mapas que se adequavam dentro desse período histórico. Posteriormente realizou a pré-seleção para identificar os mapas que continham informações pertinentes. Após a pré-seleção todos os mapas foram transferidos para o meio digital. Na etapa de processamento dos mapas, foi realizada o georreferenciamento seguido da vetorização. Para georreferenciar o mapa adotou-se o método master/slave, onde utiliza-se uma imagem de coordenadas conhecidas (master), e associa-se a imagem sem coordenadas definidas através de pontos comuns entre elas. Após os mapas georreferenciados, todos os mapas foram vetorizados, o que tornou possível colocar em um mesmo banco de dados as 
informações dos mapas dos diferentes períodos, facilitando assim a comparação e a criação dos mapas de sínteses para ajudar na análise das mudanças que ocorreram no centro urbano do Rio de Janeiro.

Figura 2: Fluxograma Fases metodológicas para análise de Cartografia Histórica

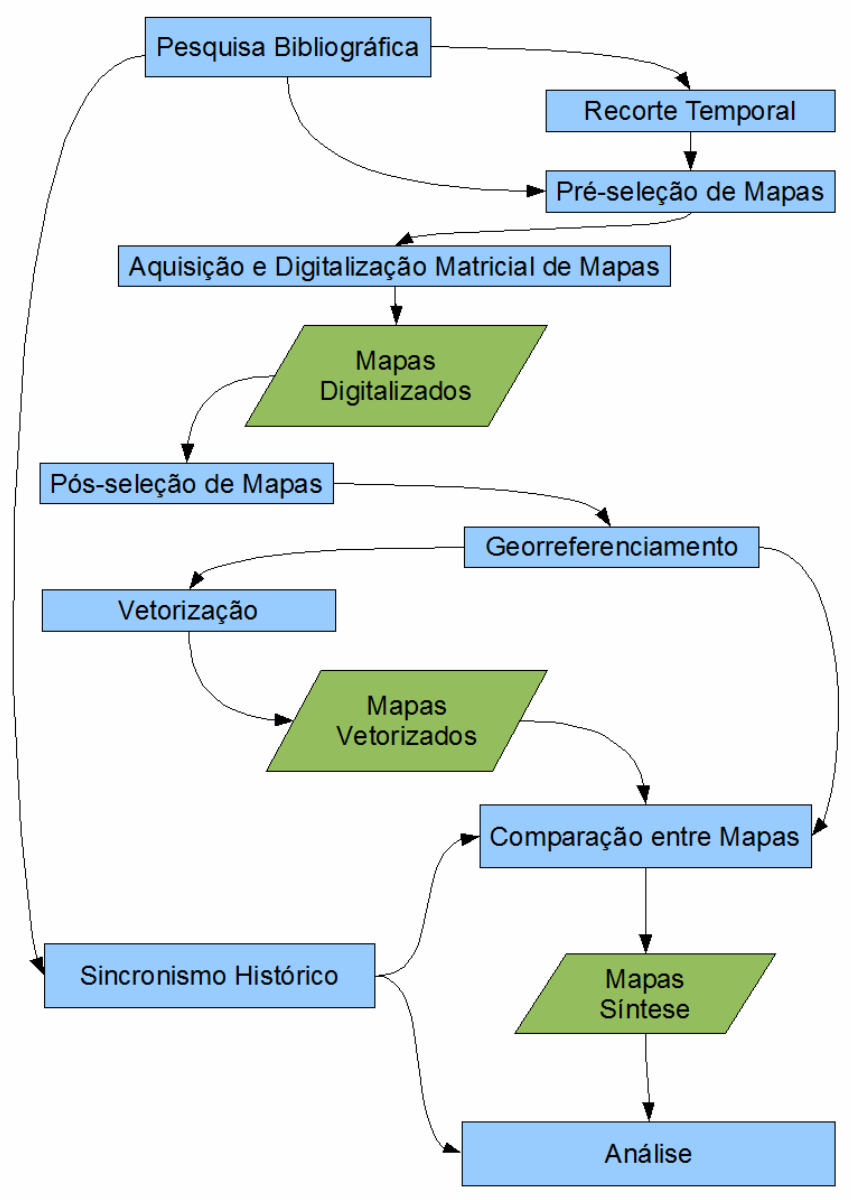

Fonte: Corrêa (2008).

\subsection{Ordenamento territorial}

A expressão ordenamento territorial se remete a concepção de dois conceitos: ordem e território. Logo, entender o Ordenamento Territorial não é simples, tendo em vista a necessidade de compreender seus dois conceitos formadores e relacioná-los (HAESBAERT, 2006).

A expressão ordem, no dicionário, recebe uma gama de diferentes significados, entre eles o sinônimo de organização, ordenação, arrumação, disciplina, arranjo, lei, estrutura, administração e regularidade. Através dos diferentes significados atribuídos 
a expressão ordem, podemos perceber que este carrega uma relevante dose de subjetividade. Desta maneira, Machado (2012), expõe que um território dependendo de quem o observa pode se encontrar ordenado ou desordenado, evidenciado o grau de subjetividade da expressão. Portanto, ordenar revela a particularidade do ser humano de colocar as coisas no lugar que ele considera adequado.

A ordem, desordem e a organização se interagem, apresentando uma relação de interdependência, e a perspectiva de quem observa que definirá se é conveniente ou não o arranjo no território. Nesse sentido Haesbaert (2006) coloca que:

A "ordem" vem sempre acompanhada de seu par indissociável, a
"desordem", que não deve simplesmente, a priori, ser combatida, pois
ela pode estar sendo manifestação de uma nova ordem, de um novo
ordenamento - vide algumas formas alternativas de organização do
espaço que brotam das populações mais pobres e excluídas; o
momento da desordem geralmente coincide com aquilo que
caracterizamos como crise ou, como queria Gramsci, o momento em
que "o velho está morrendo e o novo ainda não conseguiu nascer"
(HAESBAERT, 2006, p. 117).

A compreensão do ordenamento territorial, passa pela necessidade de avaliar o conceito de território. Nas ciências naturais e sociais, a expressão território tem o uso mais antigo, e é possível observar uma variedade de significados para esse conceito. Na geografia, o território se destaca como um conceito e uma forma de estudo dessa ciência, segundo Claval (2007) na antiguidade Heródoto já apresentava conjuntos territoriais definidos pelos seus limites. Ao longo da evolução epistemológica da geografia, o conceito de território acompanhou este movimento.

O conceito de território possui uma relação muito forte com a ideia de domínio de uma determinada área, por essa questão o território é fortemente relacionado com "poder". O poder exercido em uma área pode ocorrer através do poder público, estatal ou até mesmo de grandes empresas que ignoram fronteiras políticas (ANDRADE, 2004).

O território para Haesbaert (2007) também tem relação com poder, indo além somente do tradicional "poder político". O autor coloca que o território diz respeito ao poder no sentido mais explícito de dominação, como também simbólico. Haesbaert expõe que o território também é múltiplo, diverso e complexo, logo, é contrário à ideia de território "unifuncional", que atualmente é reproduzida pela figura do Estado 
moderno, não admitindo multiplicidade/sobreposição de jurisdições e/ou de territorialidades.

Na geografia o território não deve ser confundido com espaço ou lugar. A ideia de espaço precede ao território, ou seja, o segundo se forma a partir do primeiro. Fundamentalmente o território forma quando o espaço passa a ser apropriado, estabelecendo então possíveis diferentes formas de poder (RAFFESTIN, 1993).

Raffestin compreende o papel do ator de territorializar o espaço, e esclarece que:

[...] um espaço onde se projetou um trabalho, seja energia e informação, e que, por consequência, revela relações marcadas pelo poder. (...) o território se apoia no espaço, mas não é o espaço. É uma produção a partir do espaço. Ora, a produção, por causa de todas as relações que envolve, se inscreve num campo de poder [...] (RAFFESTIN, 1993, p.144).

Através da visão de Raffestin, é possível identificar que o autor concede ao território uma evidência político-administrativa, ou seja, um espaço físico delimitado como território nacional. Além do território nacional, pode também ser um espaço delimitado por uma ordem jurídica e/ou política.

Já o ordenamento territorial diferentemente do conceito do território é um conceito recente que se encontra em processo de construção. Por vezes o conceito aparece como ciência, ora como política ou então como técnica administrativa, portanto ainda não se trata de um conceito claro (MACHADO, 2012).

O processo de ordenar o território significa identificar, distribuir, organizar e regular as atividades humanas no território, de acordo com determinados critérios. Logo, o ordenamento territorial constitui um processo que tem por objetivo orientar a ação do homem na superfície terrestre (OREA, 2008).

Já Haesbaert expõe uma ideia diferente para ordenamento territorial, segundo o autor os termos ordenar e territorializar apresentam muitas coisas em comum, gerando até uma certa redundância:

Se territorializar-se é, sobretudo, exercer controle sobre os movimentos - de pessoas, objetos ou informações - que se dão no e pelo espaço e, a partir daí, dominar e apropriar-se deste espaço, podemos dizer que formar territórios é, automaticamente, "ordená-los". Assim, haveria mesmo uma certa redundância entre os termos territorialização e ordenamento. Consequentemente, 
desterritorialização e desordenamento seriam também expressões correlatas (HAESBAERT, 2006, p. 120).

No presente trabalho trata-se ordenamento territorial na perspectiva do recorte que atualmente entendemos como município. Portanto, ficará visível ao longo deste trabalho a forte relação com as passagens de Raffestin, em que ele concede ao território uma evidência político-administrativa, e um espaço delimitado por uma ordem jurídica e/ou política. Portanto, na discussão do ordenamento territorial de um município ao longo da história, mudanças na delimitação espacial são frequentes. Raffestin coloca também que o espaço pode ser delimitado por diferentes ordens, como a jurídica e a política, e neste trabalho também a eclesiástica.

O ordenamento territorial dos municípios no Brasil também vai de encontro com o que Haesbaert expõe sobre o fato do território não ser unifuncional, e sim múltiplo. A ideia atualmente de um único poder reproduzida pelo Estado moderno é desmantelada pelo ordenamento territorial histórico dos municípios, já que é possível notar uma sobreposição de jurisdições e territorialidades no espaço que em muitos casos se confundem.

\section{AS CATEGORIAS ADMINISTRATIVAS ECLESIÁSTICAS E JUDICIÁRIAS NO ORDENAMENTO DO TERRITÓRIO E A ORGANIZAÇÃO DO TERRITÓRIO A PARTIR DO MAPA HISTÓRICO DE 1847}

O presente capítulo, se subdivide em três partes que estão interligadas, são elas: as instâncias administrativas, eclesiásticas e judiciárias, organização do território a partir do mapa histórico de 1847 e a toponímia dos municípios.

A história política administrativa e territorial de qualquer município é descrita utilizando diversos conceitos administrativos, eclesiásticos e judiciários. Enquanto alguns conceitos utilizados no passado já não existem na organização administrativa atual, outros ainda se fazem presentes, mesmo que isso não denote que tenha o mesmo significado de um tempo passado. Registro, Freguesia, Termo, Paróquia, Distrito, Vila, Cidade e Comarca são exemplos de conceitos que explicam e/ou explicaram a organização política administrativa e territorial.

Nesse cenário, no presente capítulo será realizado inicialmente uma explanação geral das diferentes categorias do ordenamento territorial para entender 
a história política administrativa e territorial dos municípios e das cidades brasileiras. A abordagem neste capítulo da história política administrativa e territorial dos municípios considera três momentos distintos: o primeiro se perpassa majoritariamente no Brasil colônia, o segundo momento já no período imperial e por fim no Brasil república. Além disso na medida que se realiza exposições sobre as diferentes categorias, busca inserir explicações sobre o processo de evolução da própria área de estudo, no caso a evolução do povoado de São João Batista do Presídio até a cidade de Visconde do Rio Branco e as diferentes instâncias evolutivas que a cidade passou da criação do povoado até a consolidação da cidade. Também vale ressaltar que além das categorias apresentadas na figura 3, outras terminologias foram utilizadas no processo de desenvolvimento do território, como: povoações e arraiais, que também são abordadas ao longo do presente capítulo.

Logo, compreender os diferentes conceitos que envolvem a organização político-administrativa e territorial do Brasil é importante, tendo em vista que a área de estudo do trabalho também está inserida dentro desta lógica.

O segundo momento do presente capítulo, consiste em a partir do geoprocessamento aplicado a cartografia histórica, representar a organização espacial da Vila de São João Batista do Presídio em 1847 a partir da interpretação e da descrição geográfica e cartográfica de João José da Silva Theodoro.

A representação utilizando como fonte o mapa histórico exigirá que diversos procedimentos, como georreferenciamento, vetorização e elaboração de uma base de dados atual da mesma área geográfica sejam constituídas para utilizar as informações contidas no mapa histórico. A partir desses procedimentos foi elaborado um mapa temático sobre uma base cartográfica atual que representa a organização políticoadministrativa e territorial de acordo com João José da Silva Theodoro.

A terceira parte do capítulo, consiste em um estudo da toponímia dos atuais municípios que pertenciam ao território do município do Presídio em 1847. A toponímia é o campo que estuda os nomes próprios dos lugares, como sua origem e evolução. Diante dessa questão, ao trabalhar com mapa histórico e compará-lo com uma base de dados atual de mesma localização geográfica foi necessário entender como os lugares de mesma localização geográfica apresentavam nomes distintos que se alteraram ao longo do tempo. 
Nessa perspectiva foi realizado um estudo utilizando fontes bibliográficas e cartográficas (leis provinciais e estaduais e o mapa histórico de 1847 e as cartas do IBGE) para compreender as mudanças da toponímia das capelas, freguesias e vilas que pertenciam ao município do presídio em 1847.

\subsection{As categorias administrativas eclesiásticas e judiciárias no ordenamento do território}

O ordenamento territorial dos municípios brasileiros pode ser dividido em três momentos distintos. O primeiro momento se estende até o ano de 1828, mais precisamente até a publicação da Lei de $1^{\circ}$ de outubro de 1828 , através desta lei que surge o vocábulo município no Brasil dentro da concepção atual do seu significado, modificando as estruturas da organização administrativa vigente. O segundo momento de 1828 até 1889, perpassa por um Brasil imperial, onde existiam três modelos de organização territorial: administrativo, eclesiástico e jurídico. O terceiro momento inicia-se com a instauração da república, que é marcado pela desvinculação da igreja e do estado, colocando fim a organização territorial pela perspectiva eclesiástica.

O modelo político-administrativo e territorial brasileiro tem suas bases no modelo de Portugal, que foi incorporado ao Brasil no período colonial. Nesse período a divisão política-administrativa consistia em comarcas, termos, vilas ou cidades, freguesias e paróquias. A divisão administrativa no primeiro momento que vai até 1828, foi caracterizada pela presença do poder judiciário e principalmente eclesiástico que foram partes presentes na organização do território.

A presença do judiciário e da igreja na organização do território pode causar alguma confusão para quem busca compreender a evolução política-administrativa e territorial de determinado município ou região. Ao analisar a evolução administrativa nos séculos XVIII e XIX, identifica-se a presença de categorias judiciárias e eclesiásticas como organizadores do território. Como cada uma dessas categorias se referem a um limite territorial distinto, torna necessário entender os seus significados. Por exemplo, a Comarca de Ubá e Vila de Ubá são categorias distintas, e abrangem diferentes extensões territoriais, enquanto a primeira refere-se a uma organização judiciária, a segunda refere-se a organização administrativa a partir do processo de desenvolvimento urbano. 
Diante dessa perspectiva, é importante reiterar que Comarcas e Termos fazem referência a organização judiciária, enquanto Freguesias, Paróquias e Curas fazem referência a organização eclesiástica. Distritos, Vilas, Cidades, Municípios, Províncias a organização administrativa. Além dessas terminologias, o processo de constituição das cidades conheceu outras categorias, que não apresentavam uma área territorial definida, mas se tratavam do ponto de partida para os futuros distritos ou cidades, as categorias incipientes consistiam nos Pousos, Registros e Arraiais.

Figura 3: Diferentes categorias da história-político administrativa e territorial

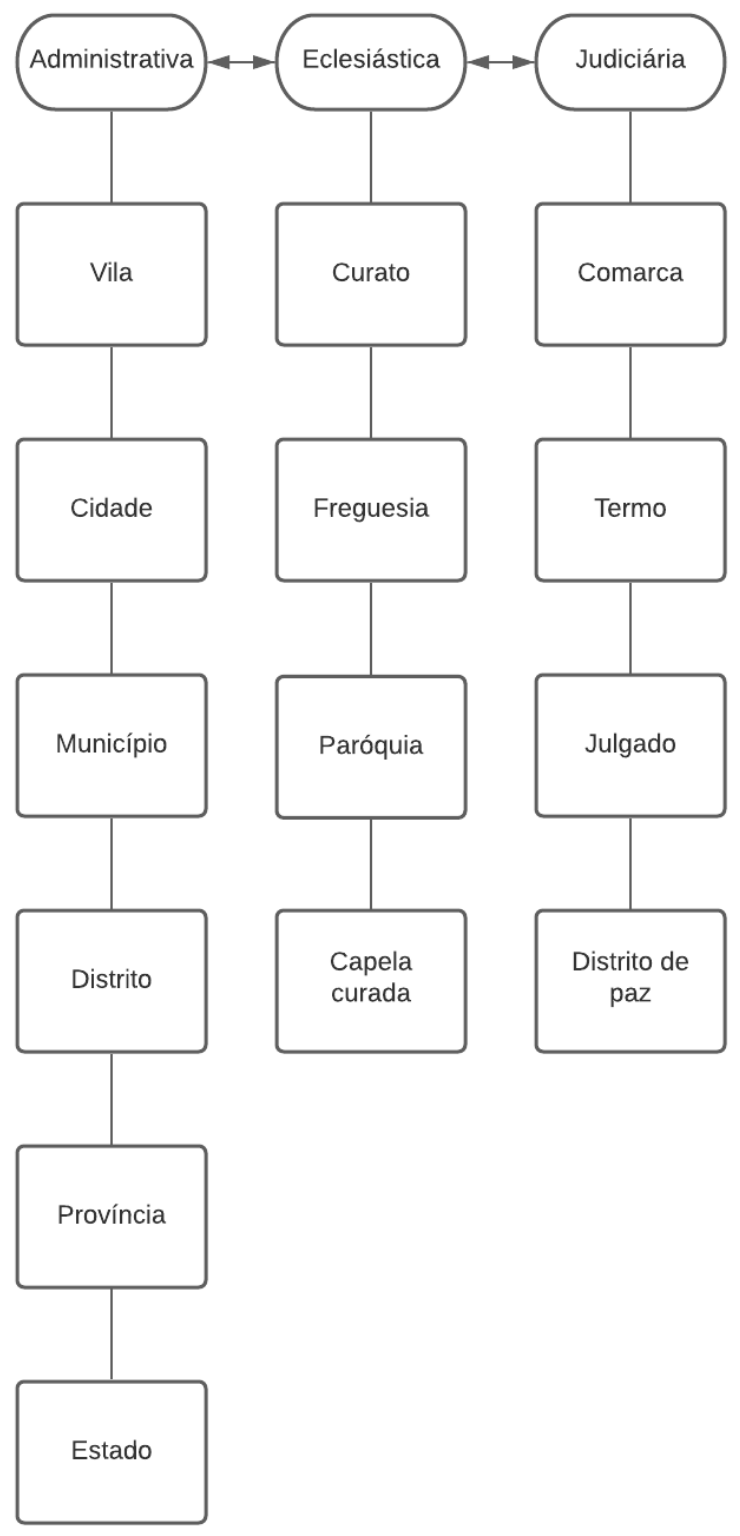

Fonte: Elaborado pelo autor (2021). 
A figura 3 representa as diferentes categorias que compõem o ordenamento territorial, apesar da figura apresentar de forma linear e estrutura, é importante ressaltar que as categorias muitas vezes se confundiam e sobrepunham. O glossário a seguir busca representar os significados das categorias de uma maneira sintetizada para auxiliar a leitura do capítulo.

Tabela 1:Glossário com significado das categorias que compõem o ordenamento territorial.

\begin{tabular}{|c|c|}
\hline \multicolumn{2}{|r|}{ Glossário } \\
\hline Categoria & Significado \\
\hline \multicolumn{2}{|l|}{ Administrativa } \\
\hline Vila & $\begin{array}{l}\text { Nos dicionários vila normalmente aparece como aglomerado } \\
\text { populacional menor que a cidade. A vila estabelece a criação de uma } \\
\text { câmara, o que faz da vila a sede do antigo termo e dos municípios. }\end{array}$ \\
\hline Cidade & $\begin{array}{l}\text { Área com uma concentração de habitantes. A cidade é a sede do } \\
\text { município. }\end{array}$ \\
\hline Município & $\begin{array}{l}\text { Divisão administrativa com circunscrição territorial própria. Apresenta } \\
\text { certa autonomia administrativa. }\end{array}$ \\
\hline Distrito & $\begin{array}{l}\text { O distrito é a circunscrição primária do território estadual, para fins de } \\
\text { administração pública e da organização judiciária. }\end{array}$ \\
\hline Província & $\begin{array}{l}\text { Entidade com certo grau de autonomia dotada de governo e constituição } \\
\text { própria. No Brasil surgiu a partir das capitanias e na república se } \\
\text { transformou nos estados. }\end{array}$ \\
\hline Estado & $\begin{array}{l}\text { Entidade com certo grau de autonomia dotada de governo e constituição } \\
\text { própria. O território da União se subdivide em estados, enquanto os } \\
\text { estados são subdivididos em municípios. }\end{array}$ \\
\hline \multicolumn{2}{|l|}{ Eclesiástica } \\
\hline Curato & $\begin{array}{l}\text { Zona ou área provida de um cura (padre) residente para cuidar das } \\
\text { atividades religiosas sob a dependência de uma paróquia, mas com certa } \\
\text { autonomia. }\end{array}$ \\
\hline Freguesia & $\begin{array}{l}\text { Definição primária da estância eclesiástica. A freguesia pode ser } \\
\text { entendida como o território que está sob jurisdição do pároco. A } \\
\text { freguesia abrangia outros povoados que não possuíam sua paróquia e } \\
\text { acumulava funções administrativas. }\end{array}$ \\
\hline Paróquia & \\
\hline
\end{tabular}




\begin{tabular}{|c|c|}
\hline & $\begin{array}{l}\text { Paróquia é o local onde contém seu próprio pároco e é celebrado o ofício } \\
\text { divino. Pode-se entender a paróquia como sinônimo da freguesia. }\end{array}$ \\
\hline Capela curada & $\begin{array}{l}\text { Localidades onde as capelas recebiam um cura provido pelos bispos, } \\
\text { esse cura era encarregado da assistência espiritual dos habitantes dos } \\
\text { arraiais mais distantes da sede da paróquia. }\end{array}$ \\
\hline \multicolumn{2}{|l|}{ Judiciária } \\
\hline Comarca & $\begin{array}{l}\text { O nome comarca se remete aquilo que é demarcado, limitado. Portando } \\
\text { é uma circunscrição jurídica que abrange a área em que o juiz exerce } \\
\text { sua jurisdição. Pode abranger um ou mais municípios. }\end{array}$ \\
\hline Termo & $\begin{array}{l}\text { Base territorial abrangida pela jurisdição de uma vila ou cidade, que } \\
\text { seriam, as sedes do poder. Por isso "Termo da vila" ou "Termo da } \\
\text { cidade", pois nessas localidades se encontravam a centralidade do } \\
\text { poder, não só judiciário mas também político e administrativo. }\end{array}$ \\
\hline Julgado & $\begin{array}{l}\text { Localidades distantes da sede de jurisdição da justiça criavam } \\
\text { dificuldades para administração da justiça. Nessa perspectiva que foram } \\
\text { criados os julgados, que eram novas sedes com autonomia parcial. }\end{array}$ \\
\hline Distrito de paz & $\begin{array}{l}\text { Os distritos de paz eram aquelas localidades que recebiam um juiz de } \\
\text { paz (responsável por decidir verbalmente pequenas contendas entre } \\
\text { moradores de um determinado local), como o juiz de paz atuava nos } \\
\text { distritos, o local se elevava então a distrito de paz. }\end{array}$ \\
\hline
\end{tabular}

Fonte: Elaborado pelo autor a partir das interpretações de Martins e Soares, 2016.

\subsubsection{Do período colonial a Lei Geral de $1^{\circ}$ de Outubro de 1828}

O processo de formação territorial de Minas Gerais foi impulsionado pela corrida pelo ouro. O primeiro povoado mineiro data 1674 , denominado Ibituruna, a partir de então inicia-se a evolução organizacional do arcabouço políticoadministrativo. O modelo organizacional, devido ao período Brasil colônia tem forte influência da metrópole portuguesa. Em Portugal o elo principal da organização da malha urbana era o Concelho, que apresentava mesmo significado que vila e cidade (FONSECA, 2011).

O período colonial até 1822 foi marcado pela forte relação entre poder administrativo, eclesiástico e judiciário no ordenamento do territorial. As capitanias, que mais tarde foram chamadas de províncias, e finalmente na República foram intituladas como Estados, eram divididas no período colonial em: comarcas, termos, vilas, cidades, freguesias e paróquias. Todos as divisões faziam parte do ordenamento do território, e a mistura entre diferentes poderes atuando no 
ordenamento do território contribuiu para gerar certa dificuldade na interpretação da organização do mesmo.

A evolução territorial do estado de Minas Gerais inicialmente se remete a categoria arraial, que caiu em desuso, mas no século XVIII e XIX era central no espaço pré-urbano. O Arraial pode ser considerado a unidade primária da formação urbana, onde a partir desse estágio surgiam povoações mais consistentes. Tal terminologia chama atenção pelo fato de Portugal, principal influência no modelo organizacional brasileiro não utilizar esta categoria com o mesmo significado que este ganhou no Brasil pré-urbano. Em Portugal a incipiente aglomeração urbana era denominada aldeia ou povoado.

Segundo Mata a palavra arraial adquire uma variedade de significados, como acampamento militar, povoação temporária, pequena aldeia, ajuntamento festivo de povo entre outros significados. Porém Mata destaca que o sentido primitivo da palavra corresponde a acampamento, e que a evolução da palavra inserindo o termo real (de realeza), ocorreu pelo costume comum do soberano acompanhar seus exércitos nas campanhas, culminando na categorial do arraial (MATA, 2002).

Os relatos seiscentistas trazem o arraial com uma conotação militar, aparecendo sempre como sinônimo de acampamento. Mata também analisou diferentes tentativas de definição de arraial dos anos posteriores. Leloup definiu que os arraiais foram acampamentos de mineradores, já Angela Garcez considerou como arraiais os vilarejos primitivos que se foram formando ao longo do processo colonizador. A melhor definição de arraiais para Mata foi a do viajante Saint-Hilaire, que ao percorrer as terras da províncias na primeira metade do século XIX trouxe o seguinte relato sobre os arraiais:

Uma praça, por vezes bastante ampla e em formato retangular, em torno da qual dispunham-se habitações, e uma igreja ou capela - as vezes uma venda - compunham o perfil básico do arraial mineiro em fins do período colonial. Muitos deles permaneciam praticamente vazios durante os dias de semana, e só eram 《ipreenchidos》 em ocasiões de missa e de festa. (MATA, 2002, p.50).

A partir da definição de Arraial e considerando a área de estudo, o atual município de Visconde do Rio Branco tem suas origens na criação de seu arraial. A criação do arraial de São João Batista do Presídio data 1787 e reforça como poder eclesiástico que apresentava grande influência na formação do espaço pré-urbano. 
Vinte anos antes da criação do arraial o sacerdote Manoel de Jesus Maria se encontrava na região para incentivar seu crescimento e com a missão de ensinar princípios religiosos a população. Como vigário de S. Manoel dos Sertões do Rio Pomba e Peixe dos Índios Croatos e Cropós, Manoel de Jesus e Maria continuou seu trabalho missionário e em 1787 autorizou-se a criação da capela dedicada a São João Batista. A inauguração da capela também naquele ano marca a criação do arraial de São João Batista do Presídio, a data inclusive se faz presente na bandeira do atual município (PINTO, 2002).

A definição de arraial e os relatos descritos por Saint-Hilaire compactuam com as características pré-urbanas do então arraial de São João Batista do Presídio. O arraial estava situado em meio a uma mata densa, composto de cerca de trinta residências rústicas que estavam distribuídas ao entorno de uma praça central. Ao alto de uma leve colina a presença da capela, tal construção representava o marco de criação do arraial (TAVARES, 2013).

O arraial definia a formação do povoado inicial, não apresentava nenhum aspecto como definidor do ordenamento do território, mas era o primeiro passo, o seu contínuo desenvolvimento poderia significar no futuro a garantia de "títulos" maiores até a consolidação de uma possível vila. O caminho de desenvolvimento do arraial apresentava como próximo passo atingir um título da estância eclesiástica: freguesia.

A freguesia era uma definição primária da estância eclesiástica, mas apresentava forte ligação com poder administrativo no período colonial. Mata (2002) explica que apesar das freguesias se apresentarem como base da organização eclesiástica, elas exerciam também uma função administrativa, isso ocorria porque a partir da instituição das freguesias a metrópole passa a ter maior controle sobre os arraiais que estavam surgindo. Além disso, Fonseca (2011) esclarece que as freguesias serviam como base para a realização dos recenseamentos e das cobranças de impostos por parte do poder administrativo. Por fim, Marx (1991) explana que enquanto as instâncias administrativas estavam distantes dos arraiais que surgiam afastados dos grandes núcleos de interesse da metrópole, a igreja no início do desenvolvimento dessas localidades já impunha suas questões hierárquicas.

A categoria freguesia tem como sinônimo a paróquia. Martins e Soares em pesquisa nos dicionários sobre as duas palavras concluíram que ambas apresentam semelhanças que os colocam como sinônimos. Em suas pesquisas encontraram que 
Parochia em grego quer dizer vizinhança, e também é na paróquia o local onde através do pároco e de seus vigários que é celebrado o ofício divino. Pode-se estender também o significado como o território que está sob a jurisdição do pároco (MARTINS; SOARES, 2016).

O reconhecimento da construção de uma capela pela igreja representava um marco, pois a partir de então aquele povoado se tornava mais estável e consolidado. Basicamente a titulação de freguesia, significava que o povoado pelos seus aspectos populacionais e de desenvolvimento já se encontravam em um estágio para ter o seu próprio pároco.

A organização eclesiástica na província mineira se assemelhava a organização europeia. A freguesia era a representação do templo - igreja -, da povoação sede, das áreas rurais e também abrangiam outras povoações incipientes (arraiais) que ainda não eram freguesias. Logo, uma paróquia podia abranger vários povoados, e na província mineira a extensão territorial das paróquias ou freguesias chamavam atenção. Em 1745, enquanto em Portugal existiam 3.987 freguesias, nesse mesmo período em Minas Gerais que apresentava um território seis vezes maior existiam algo próximo de cinquenta freguesias. Obviamente a discrepância se deve ao ainda pouco numerosos e incipientes núcleos pré-urbanos que existiam na província mineira, mas demonstra como o poder eclesiástico era utilizado para traçar as divisões no território (FONSECA, 2011).

A elevação do arraial a freguesia oficializava a unidade territorial perante o Estado. Porém o novo status garantia para a população outras benfeitorias. A população passa a adquirir o direito a assistência religiosa e aos processos que permeavam pela responsabilidade da igreja. Não era necessário mais locomover uma grande distância para o batismo, o mesmo válido para o casamento ou para o sacramento na morte. A agora paróquia também tinha a responsabilidade perante o estado de registrar os acontecimentos da comunidade como os registros de nascimento e de óbito. São esses os fatores que explicam o anseio da comunidade de dar um passo maior do que apenas construir uma capela para suas atividades religiosas, almejava-se também a sua oficialização e reconhecimento como paróquia. Tal status além de garantir o simbolismo de sagrar aquele espaço e do reconhecimento perante o Estado, garantia também uma série de facilidades a população (MARX, 1991). 
A seguir a proposta deste capítulo opta-se por fazer uma análise do processo de evolução da área de estudo onde esta foi elevada para freguesia, categoria do ordenamento territorial explicado por agora. O arraial de São João Batista do Presídio reconhecido como tal em 1787, permaneceu com esse status até 1810, quando então foi elevado a nova condição de freguesia, ou seja, a construção de sua capela que garantiu o reconhecimento do arraial em 1787 fora elevada a paróquia, consolidando a freguesia.

O documento que consolida a freguesia trata-se da Resolução de 24 de julho de 1810, quando este coloca que "erige em freguesia a Capela Curada do Presídio de São João Batista, do Bispado de Mariana". No documento consta que o requerimento a elevação da Capela Curada a freguesia foi recusado pelo Bispo de Mariana, que naquele período era Cipriano de São José, porém ele foi voto vencido, tendo o Procurador da Coroa e da Fazenda acatado positivamente o requerimento.

A resolução de 24 de julho de 1810 remete em seu texto a elevação de Capela Curada a freguesia. Tendo em vista o que já foi elucidado sobre a categoria freguesia, a compreensão do seu significado é clara. Porém a categoria Capela Curada que está presente na resolução carece de uma explicação do seu significado.

A Capela Curada remete as classificações eclesiásticas auferidas pelo poder da Igreja. Neste período ocorria uma divisão em curatos e freguesias coladas. A diferença entre elas se dá basicamente pelo fato de os curatos receberem um vigário encomendado pelo bispo, enquanto na freguesia o vigário era indicado pelo rei. Além dessas existiam também a Capela Curada definida por Martins e Soares (2016) como aquelas em que recebiam um cura provido pelos bispos, e esse cura era encarregado da assistência espiritual dos habitantes dos arraiais e fazendas mais distantes da sede da paróquia.

A partir da definição da Capela Curada é possível explicar tal título a então capela de São João Batista do Presídio antes desta ser elevada a freguesia em 1810. Como definiu Martins e Soares, as Capelas Curadas eram aquelas que recebiam assistência de um padre, onde esse saia da sede da paróquia para atender as pessoas assistidas pela Capela Curada. Nesta perspectiva, sabe-se que o vigário Manoel de Jesus e Maria da Freguesia de Mártir São Manoel do Rio da Pomba e Peixe dos Índios Croatos e Cropós prestava assistência a capela de São João Batista do Presídio, tendo inclusive auxiliado em sua fundação como mencionado neste capítulo. 
A freguesia do vigário Manoel era a única com este título na região próxima ao arraial São João Batista do Presídio no período em questão. Logo, sua participação na capela a classificou como Capela Curada.

O presente capítulo abordou estâncias presentes no ordenamento do território, como o arraial, Capela Curada e Freguesia (Paróquia). Tendo em vista que as estâncias eclesiásticas já foram esgotadas, a partir de então nos próximos parágrafos será realizado uma breve elucidação sobre as outras estâncias dos poderes judiciários e administrativos que ainda não foram explicadas. Os exemplos utilizando a área de estudo não aparecerão por agora, como vinha ocorrendo. A ideia é exemplificar com a área de estudo respeitando o período do acontecimento.

O primeiro momento que se remete até 1828 , se perpassa majoritariamente pelo Brasil colônia. A organização administrativa neste período permeava ao entorno de duas estâncias: vilas e cidades.

A vila aparece nos dicionários do século XVIII como povoação de menor graduação que a cidade, porém maior que a aldeia. Para ser considerado vila também era necessário a presença de juiz, câmara e pelourinho. Logo, era na vila o centro do poder civil, judiciário e religioso. Assim, quando se elevava determinado povoado a condição de vila, ocorria a criação da câmara e a formação dos oficiais camarários, estes oficiais correspondiam aos vereadores e um juiz eleito ou indicado pela coroa (MARTINS; SOARES, 2016).

A cidade no século XVIII apresentava-se no dicionário como povoação superior a vila. O título de cidade significava o enobrecimento daquele local e de sua população. O título era requerido quando aquela localidade conseguia feitos importantes e também quando era local de residência de pessoas respeitáveis. Porém o título de cidade era apenas honroso, pois a elevação de uma vila a condição de cidade não garantia outras obrigações ou benefícios (FONSECA, 2011).

O período em questão quando analisado a área de estudo evidencia-se que não existia pela região a presença de vilas ou cidades. Como se trata do grau mais avançado que uma localidade poderia receber, apenas as povoações que eclodiram primeiro a receberam. No período colonial, apenas dezesseis povoados da província se elevaram a condição de vila, e esses povoados se localizavam na região da mineração onde estava centrada a ocupação impulsionada pelo fascínio ao ouro. 
A região da Mata ou os sertões do leste pelo fato de permanecerem por um período maior como áreas inexploradas não detinham nenhuma povoação com o grau de cidade ou vila. Mesmo que em algumas áreas da Mata suas ocupações sejam tão antigas quanto as da região das minas, a estrutura dos povoados não atingira a expressão que aqueles localizados na região central mineradora. Para os governantes os povoados da Mata não apresentavam importância econômica, nobreza dos habitantes, beleza das igrejas ou ruas regulares para conferirem títulos mais elevados aos seus arraiais. A situação é corroborada quando observa-se o marco temporal das elevações das vilas na região da Mata, onde a primeira vila na região somente foi erguida 1831, através da Vila de São Manoel do Pomba, sendo a segunda à Vila de São João Batista do Presídio em 1839 (CARNEIRO e MATOS, 2010).

A organização judiciária neste período se dividia em comarcas, julgados e termos. A Comarca engloba diversos municípios que estão sujeitos ao poder Judiciário de uma sede. Anteriormente a 1828, tendo em vista que a categoria município ainda não era utilizada no Brasil, a Comarca englobava diversas vilas, cidades e arraiais. A Comarca no Brasil colônia consistia em uma jurisdição que era exercida por um ouvidor, e refere-se a divisão territorial do Estado quanto a área de influência da justiça (MARTINS; SOARES, 2016).

Os julgados foram criados com a finalidade de administrar a justiça em maior extensão territorial da província. Como no século XVIII existiam poucas vilas, essas vilas apresentavam uma grande extensão territorial e vários arraiais ficavam distantes da sede de jurisdição. Visando solucionar essa questão os julgados foram criados em alguns arraiais com autonomia judiciária, mas submetidos administrativamente a sede da vila (FONSECA, 2011).

Os termos basicamente se referem ao espaço de abrangência da jurisdição de seus juízes. A sede do termo (câmara) localiza-se na povoação principal, ou seja, a vila. Por isso encontra-se em leis informações referentes a "termo da vila", já que esta demarca a extensão territorial que está subjugada pelo poder das decisões na câmara. Pode-se dizer que o sucessor do termo será o município, a diferença entre o termo e o município é que o primeiro refere-se a uma divisão do território para suprir questões judiciárias, já o município surgirá voltado para questões administrativas (MARTINS; SOARES, 2016). 
A Comarca no Brasil colônia consistia em uma jurisdição que era exercida por um ouvidor, enquanto no Brasil império a jurisdição passou a ser exercida por um Juiz de Direito, indicado pelo Imperador. No Brasil república, foi mantido a Comarca como termo administrativo da justiça. Logo, apesar de mudanças referentes a jurisdição interna das Comarcas, desde a sua criação até os dias atuais esta refere-se a divisão territorial do Estado quanto a área de influência da justiça (MARTINS; SOARES, 2016).

\subsubsection{Da Lei Geral de $1^{\circ}$ de Outubro de 1828 até o Brasil República}

O segundo momento da divisão política-administrativa e territorial retratada neste capítulo, perpassa pelo período imperial. Assim como no Brasil colonial, as circuncisões eclesiásticas, administrativas e judiciárias se complementavam na divisão política-administrativa de Minas Gerais.

A divisão do território basicamente ocorria da seguinte forma: a província (Estado) era dividida em Comarcas, a estância de maior extensão territorial que tratase de uma divisão do território a partir dos interesses do poder judiciário. O território de uma Comarca subdividia-se em mais de um município, e este trata-se de uma estância do poder administrativo. O território de um município subdividia-se em freguesias, estância do poder eclesiástico. E por fim, as freguesias se subdividiam em distritos.

$\mathrm{Na}$ perspectiva da área de estudo, sabe-se que em 1839 ano que São João Batista do Presídio foi elevado a condição de vila, o território do seu município se inseria dentro da Comarca do Paraibuna, uma das noves Comarcas existentes na província de Minas Gerais no período. O território do seu município subdividia-se em três freguesias. Tal divisão territorial é confirmada através da lei provincial $n^{\circ} 134$ de de 16 de março de 1839, onde estabelece em seu artigo primeiro que fica elevada a Vila a povoação de São João Batista do Presídio, "compreendendo no seu município a freguesia do mesmo nome, e as de Santa Rita do Turvo e de Arrepiados". O artigo sétimo da mesma lei estabelece que a Vila do Presídio pertencerá a Comarca de Paraibuna.

Após o retrato geral da divisão do território de uma província no período imperial, identifica-se que a alteração substancial que ocorreu nesse segundo 
momento foi o aparecimento da municipalidade no império. Através da Lei Geral de $1^{\circ}$ de outubro de 1828 foi introduzido e reforçado o conceito de Município. Definiu-se que as cidades ou vilas seriam as sedes dos municípios. Também em seu artigo 24 estabeleceu que as Câmaras municipais são responsáveis por funções administrativas, e não mais judiciárias como ocorriam com o Termo, demonstrando aqui um avanço na separação do território quanto a organização administrativa e judiciária, o que não ocorria no primeiro momento. Por essa questão considera-se 1828 como ponto central da mudança do primeiro para o segundo momento do processo da divisão política-administrativa e territorial.

A organização administrativa a partir de 1828 era abalizada na vila e nas cidades. As que já existiam neste período e as que surgiriam estavam sujeitas a esfera da municipalidade. O poder político e administrativo em todo território do município seria exercido através da Câmara Municipal construída na vila ou na cidade, logo, tanto a vila como a cidade se tratavam da sede da administração do município. Se no período colonial a diferença entre a vila e a cidade se dava apenas por um título honroso, neste segundo momento a diferença entre elas se estende um pouco além da questão honorífica. Segundo a Lei de $1^{\circ}$ de outubro de $1828 \mathrm{em}$ seu artigo primeiro, enquanto a cidade possuía em sua câmara nove membros, a vila contava com sete.

A garantia de se tornar sede de um município, ter o seu território bem definido como uma unidade autônoma dentro da província e a possibilidade de zelar pelos próprios anseios, despertava um grande interesse do povoado de se elevar até a situação de vila ou cidade. Seguindo as etapas do desenvolvimento urbano, quem pleiteava o status de vila eram as freguesias, estas aspiravam algo maior que a oficialização inicial concedida pelo poder eclesiástico e administrativo que possuía uma freguesia. Outro ponto que garantia o anseio da freguesia em se elevar a vila, é que se a administração do município estivesse sediada em outra sede, consequentemente as questões primordiais discutidas na câmara seriam em referência a sede, as demais aglomerações teriam chances grandes de ter suas demandas negligenciadas (MARX, 1991).

A freguesia para se elevar a vila deveria dar prosseguimento ao mesmo crescimento que a garantiu seu status atual. Ou seja, aumentar sua população, número de fogos e de serviços até um ponto que esse notado crescimento poderia se concretizar em elevação da sua categoria institucional. Porém é válido ressaltar que 
os relatos de viajantes pelas freguesias e vilas de Minas Gerais relatam que os crescimentos ocorriam de forma lenta ao longo do tempo, tanto que até mesmo após a elevação a vila a aparência e tipo de vida se mantinham. Outro fator é que muitos locais elevados a vila não justificavam pelo seu desenvolvimento, mas sim pela influência política. De qualquer forma, notado tal crescimento mesmo que lento em alguma freguesia, a ereção a vila era pleiteada e caso se concretizasse era necessário a tomada de diversas providências para organizar o território. Entre elas a delimitação do território do novo município em acordo com os limites com os municípios mais antigos e a definição das freguesias e demais arraiais que se enquadrariam naquele município além de sua sede (MARX, 1991).

A partir do período monárquico, a elevação a vila na província mineira se iniciou na década de 1830. É importante ressaltar que desde 1814 não ocorria a criação de vilas, o que acabou gerando uma demanda por novas divisões administrativas. Essa demanda se pautava em interesses políticos e conflitos por limites territoriais. Outro contexto importante que surgiu nesse período foi a mudança da principal atividade econômica, que passou da mineração para agropecuária. Apesar da mudança a rede urbana mineira ainda se concentrava ao entorno da antiga região mineradora, o que também foi um fator de pressão para criação de novas vilas. A partir desse novo cenário, somente na década de 1830 vinte e três vilas foram criadas. O número é tão expressivo que em todo século XIX foram erigidas noventa e cinco vilas (CHAVES, 2013).

Além da conjuntura exposta anteriormente, as mudanças no processo de arrecadação que ocorreram através da Lei de 4 de outubro de 1831 e 15 de novembro de 1831 causaram mudanças incisivas na criação de vilas na província. Após a implementação das leis, o surto de elevação de vários arraiais para a condição de vila se espalhou por Minas Gerais com um motivo de instalar repartições públicas para arrecadação de impostos. Dentro dessa lógica, insere-se a elevação a vila de Rio Pomba em 1831. A partir desta vila que São João Batista do Presídio se emancipou ainda no final da mesma década (CARRARA; MACHADO, 2020).

A então freguesia de São João Batista do Presídio elevou-se a vila em 1839. De acordo com a lei número 134 de 16 de março daquele ano a então Vila de São João Batista do Presídio consistia na sede administrativa do município que detinha como território a freguesia de mesmo nome e também as de Santa Rita do Turvo e 
Arrepiados, que atualmente apresentam o topônimo de Viçosa e Araponga. Após a publicação da lei, em 21 de setembro do mesmo ano instaurou o funcionamento da câmara municipal dando início a função administrativa as terras do município.

No presente texto levantou-se a questão da elevação de determinadas vilas por motivos de poderes políticos que não justificavam pelo seu grau de desenvolvimento. Porém quando considera o grau de desenvolvimento a partir da análise do número de fogos (habitação), constata-se que para os povoados presentes na região da mata em 1830, São João Batista do Presídio apresentava o quarto com o maior contingente com oitenta e quatro fogos (como representado na tabela 2). Para um total de trinta e cinco povoações com dados do número de fogos, São João Batista do Presídio encontrava-se atrás apenas de Piranga, Ponte Nova e Itaverava, povoados mais distantes. Logo, pelo número de fogos, São João Batista do Presídio apresentava um desenvolvimento significativo se comparado com outros povoados vizinhos, corroborando com o fato que a elevação de São João Batista do Presídio a vila em 1839 a princípio se pautava em seu desenvolvimento.

Tabela 2:Relação das povoações dos Termos de Mariana, Queluz e Barbacena próximas de Visconde do Rio Branco, com declaração do número de fogos em 1830.

\begin{tabular}{|l|c|}
\hline Povoações do Termo de Mariana & Fogos \\
\hline Arraial e Matriz de Guarapiranga (Piranga) & 249 \\
\hline Arraial de Ponte Nova & 87 \\
\hline Arraial e Matriz do Presídio (Visconde do Rio Branco) & 84 \\
\hline Arraial e Capela das Mercês do Pomba (Mercês) & 80 \\
\hline Arraial e Matriz de Cuieté (Distrito de Conselheiro Pena) & 68 \\
\hline Arraial e Capela de São José do Xopotó (Alto Rio Doce) & 58 \\
\hline Arraial e Capela de São Gonçalo de Ubá (Acaiaca) & 42 \\
\hline Arraial e Matriz de São Manoel do Pomba (Rio Pomba) & 39 \\
\hline Arraial e Capela do Bacalhau (Distrito de Piranga) & 38 \\
\hline Arraial e Capela de Santana dos Ferros (Guaraciaba) & 37 \\
\hline Arraial e Capela das Dores do Pomba (Dores do Turvo) & 33 \\
\hline Arraial e Capela da Conceição do Turvo (Senador Firmino) & 32 \\
\hline Arraial de Capela de Santa Rita do Turvo (Viçosa) & 22 \\
\hline Arraial e Capela de São Januário de Ubá (Ubá) & 19 \\
\hline Arraial e Capela de Barroso (Paula Cândido) & 14 \\
\hline Arraial e Capela de Brás Pires & 3 \\
\hline
\end{tabular}




\begin{tabular}{|l|c|}
\hline Povoações de Queluz & Fogos \\
\hline Arraial e Matriz de Itaverava & 93 \\
\hline Arraial e Capela da Espera (Rio Espera) & 68 \\
\hline Arraial das Dores (Capela Nova) & 39 \\
\hline Povoações do Termo de Barbacena & Fogos \\
\hline Arraial e Capela dos Remédios (Senhora dos Remédios) & 76 \\
\hline Arraial das Dores do Rio do Peixe (Lima Duarte) & 13 \\
\hline Arraial de Matriz do Ibitipoca (Distrito de Limas Duarte) & 12 \\
\hline Arraial de Rio Novo & 10 \\
\hline Matriz do Engenho do Mato (Localidade de Juiz de Fora) & 2 \\
\hline Matriz de Simão Pereira & 2 \\
\hline
\end{tabular}

Fonte: RAPM - X - RELAÇÃO DAS CIDADES, VILLAS E POVOAÇÕES DA PROVINCIA DE MINAS GERAES COM DECLARAÇÃO DO NUMERO DE FOGO DE CADA UMA (1830). Editado pelo autor.

A listagem anterior (tabela 2) com as freguesias e capelas curadas da província na região da mata retrata apenas o número de fogos presentes no distrito (podemos entender como a parte urbana), não computando o território total da freguesia. Caso considerasse o número de fogos da área rural o número superaria o apresentado. Não consta na relação somente o número de fogos dos seguintes arraiais: Pinheiros Altos (Distrito de Piranga), São Miguel (Araponga), Santo Antônio (Astolfo Dutra) e Meia Pataca (Cataguases).

A freguesia de São João Batista do Presídio, após ser elevada a vila em 1839, passou por processos de mudança do seu território em diferentes períodos, todos eles envolvendo São Januário de Ubá, atual município de Ubá. Em 1853 ocorreu a primeira alteração, com a transferência da sede da vila para o arraial de São Januário de Ubá. Dessa maneira a então vila do Presídio foi suprimida e passou à condição de distrito. Tal fato se consolida pela lei provincial número 654, de 17 de junho de 1853, cujo artigo primeiro estabeleceu que ficavam "transferidas a sede da vila do Presídio para o arraial de São Januário de Ubá com a denominação de vila de São Januário de Ubá." (MINAS GERAIS, 1853).

Pouco depois, a lei provincial número 1573, de 22 de julho de 1868, em seu artigo único determinou a transferência da sede do município de Ubá "para a freguesia 
do Presídio, tomando a denominação de cidade de São João Batista do Presídio". Três anos depois, a lei provincial $n^{0} 1755$, de 22 de setembro de 1871 restaurou a sede do município em Ubá. A última alteração ocorreu em cumprimento da lei provincial de número 2785, de 22 de setembro de 1881 que em seu artigo segundo definiu a criação dos municípios de São João Batista do Presídio, "composto das freguesias deste nome, elevado à categoria de vila, de Bagres e vila de São José do Barroso, desmembradas todas do termo de São Januário de Ubá, ficando este novo município pertencendo à comarca de Ubá". Vale ressaltar que a freguesia de Bagres e de São José do Barroso que também foram desmembradas de Ubá e passaram a pertencer a São João Batista do Presídio, são atualmente os municípios de Guiricema e Paula Cândido respectivamente.

As alterações citadas não constituem evento isolado e inusitado na história política-administrativa do território mineiro. Aliás, casos parecidos ocorreram com certa recorrência. Segundo Costa (1997), as condições com que foram criados diversos municípios na província mineira fizeram com que vários deles apresentassem uma existência precária, e consequentemente sofressem com atos de supressão, para somente em anos posteriores serem novamente elevados a município. As supressões ocorreram - como no caso de Presídio - por meio da transferência de sede do município para outra povoação, já outros casos se definiam apenas com a extinção do município. Os municípios que passaram por esse processo em Minas Gerais nos dois primeiros séculos, com a capitania e depois com a província, somam trinta casos, sendo dois deles referentes a Ubá e Visconde do Rio Branco.

$\mathrm{Na}$ análise dos casos de supressões, foi possível identificar a ausência de uma norma que pré-estabelecesse critérios sólidos que definissem quando suprimir um município. E conforme esclareceu Costa (1997), a supressão em boa parte dos casos significava a transferência da sede para uma outra povoação. Dessa forma, um padrão identificável é que a transferência de sede para outra povoação ocorria quando a então sede perdia o posto de principal ou maior povoado no que tange o desenvolvimento urbano. Logo, o crescimento e o desenvolvimento de um outro povoado que supere o da sede, poderia resultar em uma transferência de sede do município. 
No caso de Visconde do Rio Branco e Ubá, as transferências ocorreram baseadas nos motivos citados no parágrafo anterior, complementada por uma disputa política entre os povoados para qual de fato deveria ser a sede do município.

Na década de trinta do século XIX, o povoado de São João Batista do Presídio apresentava maior grau de desenvolvimento urbano frente ao povoado de São Januário de Ubá. O número de fogos no povoado do Presídio neste período era superior a quatro vezes (tabela 2) o número de fogos em São Januário, logo essa diferença justifica a criação do município de Presídio em 1839, com a sede em seu povoado.

Nas décadas seguintes o crescimento do povoado de São Januário resultou nas transições de sedes mediante a decisões tomadas pela assembleia legislativa da província. O censo do IBGE de 1872, um ano após a transferência de sede para Ubá, demonstra o crescimento de Ubá em um ritmo mais acelerado que do Presídio. Através do censo, analisando o número de fogos, a paróquia de São Januário de Ubá apresentava 1244 fogos, e uma população total de 11267 pessoas. Já a paróquia de São João Batista do Presídio continha 987 fogos, e uma população de 6078 pessoas.

No processo de transferência de sede entre Ubá e Visconde do Rio Branco no século XIX, o interesse em se manter ou se tornar a sede se manifestava em disputas através dos principais nomes políticos dos povoados. Algo justificável, na medida que se a administração do município se encontra em outra sede, maiores são as chances de suas demandas serem negligenciadas. Nessa perspectiva, Carlos Peixoto de Melo prefeito de Ubá em 1868, renunciou a seu cargo quanto a possibilidade de transferência da sede do município para Presídio, o que de fato ocorreu naquele ano. Porém, o mesmo teve papel fundamental na articulação para devolver o status de sede do município para Ubá em 1871. A disputa neste período se deu por parte dos conservadores de Carlos Peixoto de Melo contra os liberais de Presídio (CARNEIRO FILHO, 2009).

No período imperial a Vila de São João Batista do Presídio após o imbróglio de supressões e elevações que perdurou até 1881 foi elevada ao maior nível hierárquico administrativo. Através da lei provincial número 2995 de 19 de outubro de 1882, o artigo único descreve: "Fica elevada à categoria de cidade, com o título de cidade Visconde do Rio Branco, a vila do Presídio". A elevação da vila a cidade ocorreu um ano após Presídio retomar a condição de vila, tendo em vista que até 1881 sua vila 
estava suprimida a condição de distrito de Ubá. Outro ponto é que o grau de cidade acompanhou um novo topônimo. O novo nome em homenagem ao estadista José Maria da Silva Paranhos, o Visconde do Rio Branco foi uma iniciativa do então deputado José Pedro Xavier da Veiga.

A elevação de uma vila a cidade era justificada pelo grau de suas aglomerações urbanas, mesmo que são vários os casos de centros urbanos que receberam o título de maior hierarquia sem justificá-lo pelo seu grau de desenvolvimento. Exemplos como Cabo Frio na província do Rio de Janeiro demonstram que as vezes essas categorias eram atingidas também por questões geopolíticas ou de outros interesses. No Brasil não foram muitas as aglomerações a atingirem o nível de cidade até o período republicano. No tempo da independência eram somente doze, e ao surgirem as ferrovias somente 184. No Brasil império, com a centralização do poder a elevação a cidade era sancionada pelas assembleias e pelos governos provinciais, esses compostos em sua maioria por grandes proprietários de terra. Logo a elevação a cidade para ser aprovada estava atrelada também a um possível interesse dos proprietários de terras que compunham as assembleias (MARX, 1991).

No que se refere a organização judiciária no Brasil império o território dividiase em comarcas, julgados e distritos. Assim como no Brasil colônia, as províncias continuaram divididas em Comarcas. Com o desenvolvimento de novos núcleos urbanos, novas Comarcas foram criadas, São João Batista do Presídio que pertencia a comarca do Paraibuna por exemplo, quando novamente elevada a vila em 1881 pertencia a comarca de Ubá. Os termos e os julgados mantiveram os significados do Brasil colônia, porém o segundo perde relevância, tanto que não existe notícias de criações de novos julgados. Por fim, no Brasil império prossegue com a criação de diversos distritos de paz, estes distritos basicamente se referiam a área onde atuavam os juízes de paz, cada freguesia ou capela continham um juiz de paz. Como o campo de atuação do juiz era definido pelo distrito de paz, criou-se assim uma nova delimitação territorial, que a princípio no Brasil imperial tratava-se de uma delimitação exclusivamente judiciária (MARTINS; SOARES, 2016).

A divisão eclesiástica no Brasil a partir de 1828 ainda marca a forte relação entre divisão eclesiástica e administrativa, a lgreja ainda se fazia muito presente no Estado. Nesse período, principalmente até meados do século XIX a divisão eclesiástica, em freguesias, tem papel central até mesmo sobre as organizações 
administrativas e judiciárias. A igreja estava tão presente que os eleitores eram inscritos por paróquia, e se necessário, os párocos desempenhavam funções de um juiz de paz. Ao longo do Brasil império, o papel de atuar sobre as divisões eclesiásticas cabia a Assembleia Provincial, porém com a crescente instauração do conceito de município, estabelecer as divisas das freguesias e paróquias respeitando os limites municipais foi uma tarefa difícil nesse período. Como os limites das freguesias não eram precisos, comumente as freguesias ocupavam mais de um município. O Decreto de 8 de novembro de 1831, tentou solucionar essa questão quando em seu artigo primeiro definia que as freguesias que ocupavam diferentes municípios, ficam pertencendo a aquele em que se encontrar sua Igreja Matriz. Porém a separação entre organização administrativa e eclesiástica se resolverá somente a partir da instauração da república (MARTINS; SOARES, 2016).

\subsubsection{A organização territorial a partir da república}

A partir da república iniciou uma série de medidas que buscavam sanar os diferentes imbróglios que existiam ao entorno da organização do território. Se anteriormente a criação de vilas e cidades não respeitavam um padrão estabelecido, a partir da república aos poucos são criadas leis que buscavam definir critérios mais sólidos. A separação entre a organização administrativa e judiciária foi ficando cada vez mais consolidada, e finalmente a desvinculação entre Igreja e Estado colocou fim nos conflitos existentes entre os limites de freguesias.

A primeira mudança de grande impacto na república que altera de maneira significante a organização territorial se deu através da constituição de Minas Gerais de 1891. O seu artigo 74 definiu que a base da divisão dos municípios são os distritos, e foi a partir de então que se abandonou a divisão eclesiástica em paróquia e freguesia que persistiu durante o período colonial e imperial (BRASIL, 1891).

Ao tratar da área de estudo, o mapa de Rio Branco produzido pela Comissão Mineira do Centenário em 1927 retrata como o território se ordenava, é possível notar o fim da divisão eclesiástica e os municípios divididos em distrito (figura 4). Em 1927 o município de Rio Branco era composto pelos distritos de Guiricema, São Geraldo e Barroso (atualmente Paula Cândido). 
Figura 4: Mapa de Rio Branco produzido pela Comissão Mineira do Centenário em

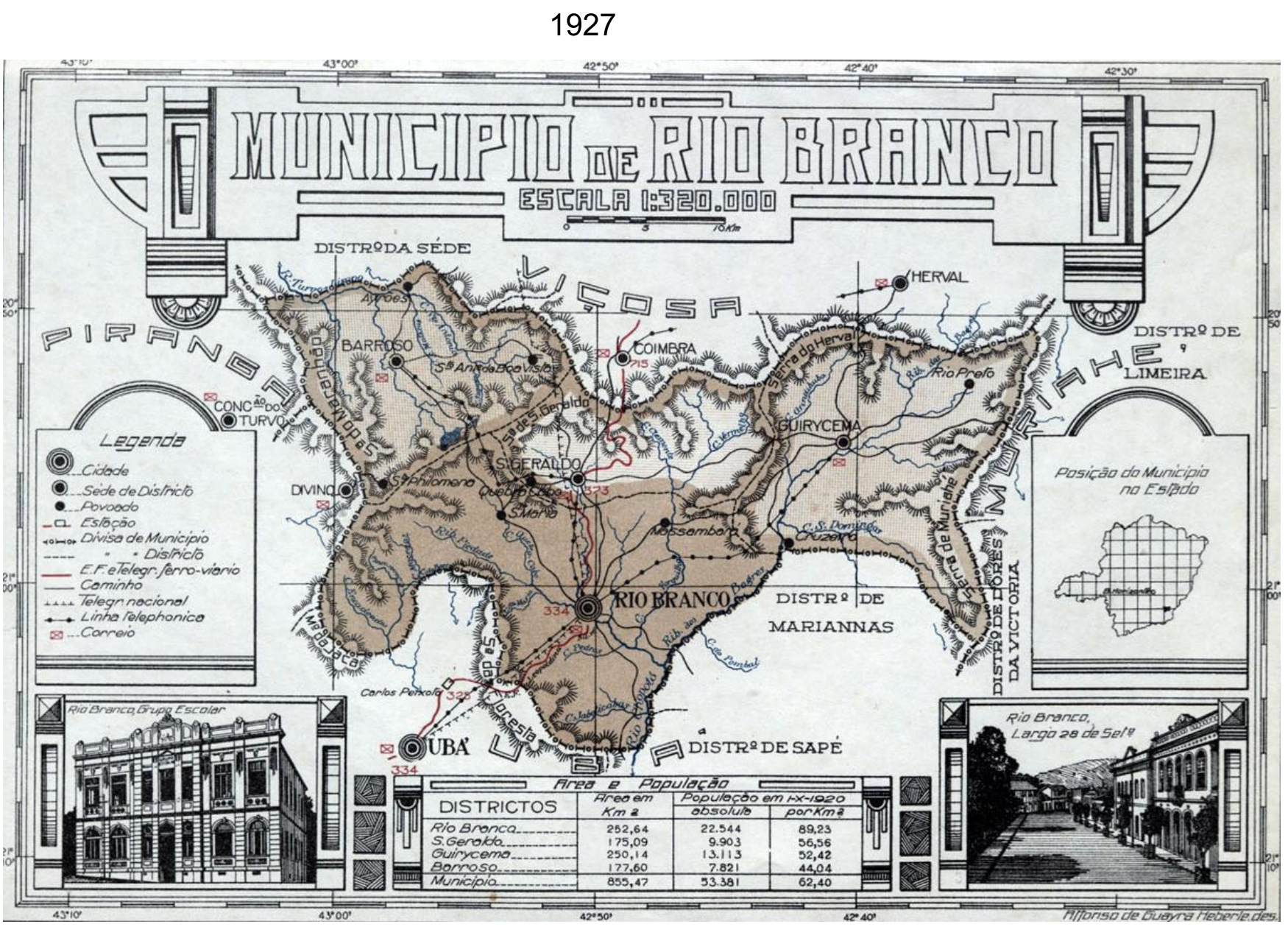

Fonte: http://www.albumchorographico1927.com.br/

Os distritos, diferentemente dos distritos de paz do período monárquico são territórios de organização administrativa inseridos no município. Logo sua circunscrição territorial demarcava até sobre onde se estendia os interesses administrativos próprios daquele distrito. Porém é válido ressaltar que o distrito, agora na república, administrativo, apresenta vínculo com os distritos de paz que existiam 
no período monárquico e se referiam a organização judiciária. Segundo Martins e Soares (2016), todos os distritos de paz existentes no Brasil Império formaram os primeiros distritos administrativos na república em Minas Gerais.

A categoria administrativa que perdeu o significado que a compunha até então foi a vila. Por muito tempo essa categoria travou uma distinção institucional com a cidade, mesmo que as vezes essa distinção não representasse sólidas diferenças entre elas, como ocorreu no período colonial. Mas o fato é que com a instauração da república, os estados foram possibilitados de estabelecer como cidade as sedes de unidades autônomas que já haviam se instalado, colocando fim na dualidade entre quais sedes mereciam o título de cidade e quais bastariam o título de vila (MARX, 1991).

Ainda na organização administrativa, na república foram se estabelecendo critérios para elevações de cidades e distritos. Uma mudança importante através da constituição de Minas Gerais de 1891 ocorreu pelo artigo 112. Neste estabeleceu-se que as mudanças administrativas ocorreriam em decênios. Tal mudança impedia alterações administrativas através de atos isolados, como ocorreu no período imperial. A constituição de Minas Gerais foi o primeiro passo para as mudanças que buscavam padronizar a organização do território.

A organização administrativa na república também esteve sobre influência do regime político nacional. A Revolução de 30 com Vargas dissolveu os poderes legislativos dos municípios. Já em 1937, a nova constituição publicada sob o regime do Estado Novo aboliu a autonomia municipal, colocando fim a eleição para prefeito. A ação de Getúlio Vargas visava centralizar o poder e retirar o poder das oligarquias que se faziam presentes nos municípios. Neste período, mesmo com os municípios sem autonomia, diversas leis e decretos relacionados a divisão administrativa foram criados nos anos seguintes, porém foi em 1938 que mudanças mais incisivas ocorreram, a partir do Decreto-lei $\mathrm{n}^{\circ} 311$.

Através do Decreto-lei $n^{\circ} 311$, de 2 de março de 1938 mudanças substanciais se consolidaram. Este decreto buscou uniformizar critérios para todo o país no que tange a divisão territorial administrativa e judiciária. O seu artigo 15 estabeleceu que as divisões do território se fariam a partir de quatro categorias: comarca, termo, município e distrito. Enquanto seu artigo 16 estabeleceu que as modificações territoriais só poderiam ser feitas através de leis gerais quinquenais. Através deste 
decreto que no mesmo ano se consolida a divisão do Estado em 219 municípios e 888 distritos. A partir desta divisão inicial, diversos distritos que pertenciam a Vila de São João Batista do Presídio em 1839 se elevaram a município, como por exemplo Guiricema.

O Decreto-lei n 311 também foi responsável por uma grande mudança no que tange a demarcação dos limites territoriais. Somado ao fato das fronteiras territoriais apresentarem uma grande fluidez, até 1938 os limites territoriais eram em sua maioria através de fazendas, o que gerava um empecilho na demarcação de territórios mais precisos. Comumente ocorriam inclusões e supressões de territórios de fazendas que transitavam entre municípios vizinhos. Esse fato se altera somente quando através do Decreto-lei de 1938 os limites municipais e intermunicipais foram estabelecidos seguindo critérios contemporâneos (CARRARA; MACHADO, 2020).

A análise das leis provinciais durante o século $X X$ demonstram que são numerosos casos de transferências de fazendas alterando os limites dos municípios em questão. Se tratando da área de estudo, somente em 1871 através da lei provincial 1800, seu artigo único estabeleceu a transferência de duas fazendas da cidade de Ubá, sendo uma delas para a freguesia de São José do Barroso (atualmente município de Paula Cândido), e a segunda para o distrito de Porto de Santo Antônio (atualmente município de Astolfo Dutra, que em 1871 pertencia ao município de Pomba). A lei provincial foi utilizada para exemplificar, mas não é a única, ainda para área de interesse são várias as leis provinciais que especificam sobre as transições de fazendas, é o caso da Lei provincial $n^{\circ} 971$ de 1859, que transfere fazenda de Rio Pomba para Ubá, o mesmo caso se repete em 1866 através da Lei provincial $n^{\circ} 1384$, que em seu artigo único transferiu três fazendas também de Rio Pomba para Ubá.

No que tange a demarcação dos limites territoriais, divide-se em dois momentos. O primeiro até 1938, marcado pela fluidez constante e limites sociais sem precisão, o segundo após 1938 que utiliza como limite acidentes naturais bem definidos. $O$ artigo $8^{\circ}$ do Decreto-lei $n^{\circ} 311$, esclareceu sobre a divisão territorial do país que os limites interdistritais ou intermunicipais deveriam ser definidos a partir de pontos de fácil identificação, seguindo acidentes naturais e não mais admitindo linhas divisórias apenas pela coincidência com divisas pretéritas ou atuais (BRASIL, 1938).

Após o Decreto-lei de 1938, foram realizadas mudanças na organização administrativa do estado através do decreto no ano de 1943 (Decreto-lei $n^{\circ} 5901$ ), 
respeitando o plano quinquenal estabelecido, onde novos municípios foram criados. Em 1948 nova mudança foi realizada através da Lei n 336, de 27 de dezembro, além de uma nova divisão, definiu-se também que o território do Estado se subdividiria apenas em município, comarca e distrito. Em 1953, através da Lei $n^{\circ} 1039$, de 12 de dezembro, foi alterada a divisão administrativa e judiciária do Estado, que passou a contar com 271 comarcas, 485 municípios e 1215 distritos. O número de municípios criados aumentou em 1953 através desta Lei, vários deles fazendo parte da área de estudo, como é possível verificar na figura 12, do capítulo 5 (MARTINS; SOARES, 2016).

O aumento de municípios a partir das leis estaduais de 1948 e 1953 ocorreu em um cenário de criação de vários municípios em todo o país. Após o fim do governo de Getúlio Vargas, a partir da nova Constituição Municipalista de 1946, foi restaurado o protagonismo dos municípios e iniciou um processo de incentivo a criação de novos municípios pelos próprios estados. O incentivo substanciou para deleitar do sistema tributário que favorecia municípios mais pobres, já que FPM (Fundo de Participação dos Municípios) distribuía cotas igualitárias para todos os municípios (CIGOLINI, 1999).

Nos anos subsequentes permaneceu o interesse para a criação de novos municípios. Através da Lei Constitucional n 6, de 16 de novembro de 1961 altera-se o artigo 170 da Constituição do Estado, e estabelece que novas divisões administrativas ocorreriam nos anos terminados em três e oito. Como já existia uma grande demanda para a criação de novos municípios, o artigo $2^{\circ}$ da mesma lei, ratificou que os pedidos que haviam sido realizados para elevação de povoado a distrito, e distrito para município no ano 1958, poderiam ser admitidos sem considerar o prazo estabelecido no artigo 170. Esse cenário explica o grande contingente de municípios criados no ano de 1962 através da Lei Estadual 2764, do mesmo ano. Esta Lei estabeleceu uma nova divisão administrativa, autorizada pela Lei Constitucional n 6 (MINAS GERAIS, 1962).

O contexto de criação de vários municípios foi interrompido durante o regime militar. Maior rigidez para a criação de novos municípios e até mesmo extinção de alguns, marcaram o período que os militares permaneceram no poder. Na década de 70 , apenas quarenta municípios foram criados em todo território nacional, o motivo foi 
a busca de maior centralização do poder, já que a criação de novos municípios significava a antítese de um poder centralizado (CIGOLINI, 1999).

O impedimento a criação de novos municípios foi substanciado através da Constituição Federal de 1967. Através dela que foram estabelecidos requisitos mais rígidos para a elevação de novos municípios, como por exemplo população superior a 10.000 habitantes, centro urbano constituído com no mínimo duzentas casas, eleitorado não inferior a $10 \%$ da população e valor mínimo necessário de arrecadação de impostos. Também foi determinado que mudanças territoriais só poderiam ser feitas quadrienalmente e no ano anterior ao da eleição municipal. Através de uma Lei Complementar $n^{\circ} 39$, de 10 de dezembro de 1980, foi determinado que a elevação ou a supressão de distritos e a transferência de distrito entre municípios, somente se concretizaria através de aprovações das Câmaras Municipais interessadas.

Por fim, através da Constituição Federal de 1988 ficou estabelecido que a emancipação dos municípios somente ocorrerá após consulta prévia, realização de estudo de viabilidade e mediante a plebiscito envolvendo as populações dos municípios interessados. A partir da Constituição também ficou definido que os estados seriam responsáveis por legislar sobre a emancipação dos municípios, o que culminou em regras distintas entre diferentes estados. Consequentemente a partir de então retornou o contexto de criação de municípios em todo território nacional.

O presente capítulo demonstrou que a concepção atual da divisão administrativa do território em municípios e distritos somente começou a se formar a partir da república. Anteriormente a divisão territorial apresentava concepções e terminologias distintas da atual, por exemplo, a freguesia que se tratava de uma divisão eclesiástica, era utilizada concomitantemente com o município na demarcação do território. Portanto, para trabalhar com a demarcação do território antigo é importante deixar claro a qual instância do território está se referindo.

\subsection{A organização do território da Vila de São João Batista do Presídio a partir do mapa histórico de João José da Silva Theodoro}

O campo da Cartografia Histórica possibilita a realização de diferentes trabalhos e pesquisas que utilizam como objeto de estudo determinado mapa 
histórico. Os mapas históricos consistem em produtos cartográficos com informações relevantes, auxiliando a compreender a organização do espaço em um período antigo.

O presente capítulo se aprofundará no campo da Cartografia Histórica para entender como era a organização político-administrativa e territorial na Vila de São João Batista do Presídio. Os capítulos seguintes, também se voltaram a compreensão da organização territorial na área de estudo, porém foram baseados em referências bibliográficas, já o capítulo em questão, buscará entender a organização políticaadministrativa e territorial através de um produto cartográfico histórico.

O mapa histórico que será utilizado foi elaborado por João José da Silva Theodoro em 1847. O mapa foi realizado através de um pedido do então presidente da província de Minas Gerais, Quintiliano José da Silva. O ofício para elaboração do mapa foi emitido em 12 de junho de 1845, e o mapeamento objetivava examinar os limites da província de Minas Gerais com as províncias do Rio de Janeiro e Espírito Santo, sendo a primeira pelo trecho de Campos, e a segunda pelo trecho de Itapemirim. Para verificar os limites com as demais províncias, foi necessário delimitar o território dos municípios que se estendiam até a divisa. Nessa perspectiva que o mapa em questão delimita os municípios de São João Nepomuceno, Presídio e Pomba.

As perspectivas para 0 presente capítulo consistem em através do geoprocessamento, trabalhar com o mapa histórico e utilizar suas informações para elaborar um mapa temático atual que represente a organização do território do Presídio em 1847.

\subsubsection{Procedimentos metodológicos}

Os procedimentos metodológicos descritos neste texto, descrevem as etapas realizadas para a construção do capítulo. A figura 5 representa como os procedimentos ocorreram através de um fluxograma.

Figura 5: Fluxograma dos procedimentos metodológicos 


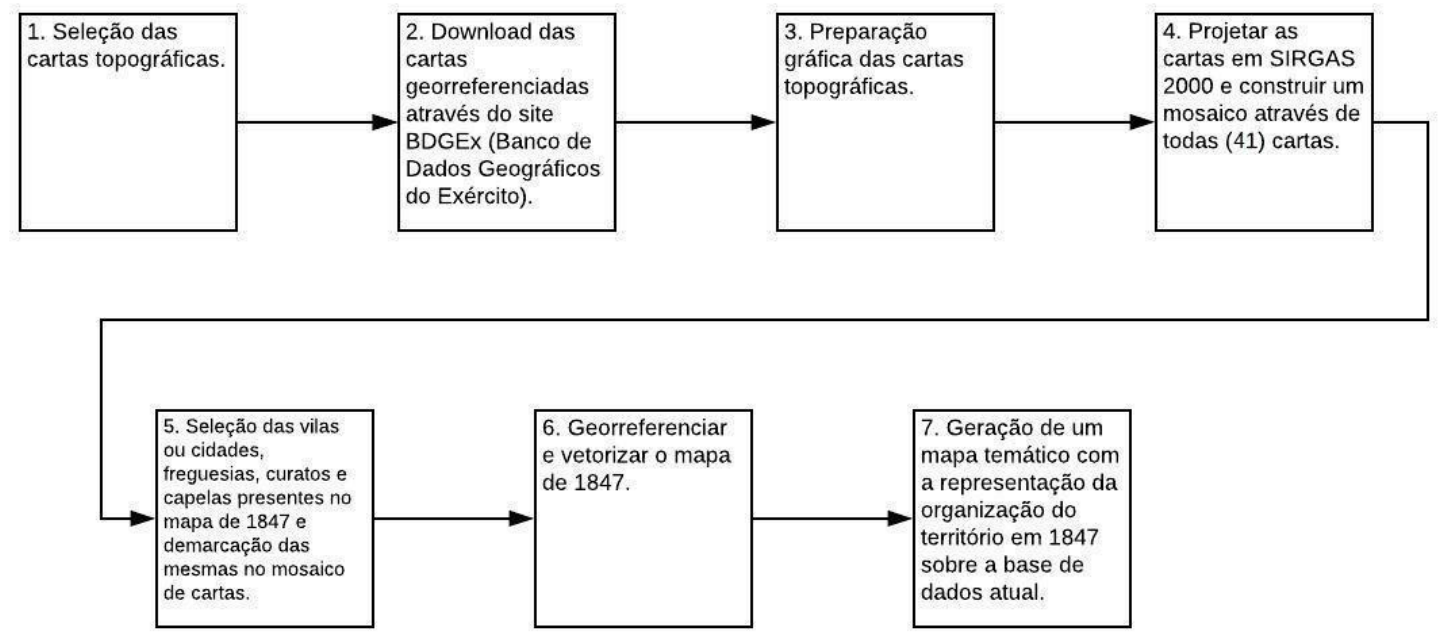

Fonte: Elaborado pelo autor (2021).

Inicialmente foram selecionadas as cartas topográficas que seriam necessárias para cobrir a mesma extensão da superfície territorial que o mapa antigo. Para a seleção considerou-se a maior escala de detalhe disponível (1:50.000) para cobrir toda a área, tendo em vista a necessidade de maiores detalhes na representação. Abarcar toda a área representada no mapa antigo significou a seleção de um total de 41 cartas topográficas: Além Paraíba (SF-23-X-D-V-4), Anta (SF-23-Z-B-II-1), Argirita (SF-23-X-D-V-1), Astolfo Dutra (SF-23-X-D-II-3), Cantagalo (SF-23-X-D-VI-3), Carangola (SF-23-X-B-VI-2), Cataguases (SF-23-X-D-II-4), Divino de São Lourenço (SF-24-V-A-IV-2), Ervália (SF-23-X-B-V-4), Espera Feliz (SF-24-V-A-IV-1), Eugenópolis (SF-23-X-D-III-2), Fervedouro (SF-23-X-B-VI-1), Guaçuí (SF-24-V-A-IV4), Juiz de Fora (SF-23-X-D-IV-1), Leopoldina (SF-23-X-D-V-2), Manhuaçu (SF-23-XB-III-4), Manhumirim (SF-24-V-A-I-3), Mar de Espanha (SF-23-X-D-IV-4), Mercês (SF23-X-D-I-1), Miracema (SF-23-X-D-III), Miradouro (SF-23-X-B-VI-3), Miraí (SF-23-XD-II-2), Muriaé (SF-23-X-D-III-1), Paiva (SF-23-X-D-I-3), Palma (SF-23-X-D-III-3), Piranga (SF-23-X-B-IV-1), Ponto Firme (SF-23-X-B-IV-2), Porciúncula (SF-23-X-B-VI4), Recreio (SF-23-X-D-VI-1), Rio Espera (SF-23-X-B-IV-3), Rio Pomba (SF-23-X-D-I4), Santo Antônio de Pádua (SF-23-X-D-VI-2), São João Nepomuceno (SF-23-X-D-IV2), São Miguel do Anta (SF-23-X-B-V-2), Sapucaia (SF-23-X-D-V-3), Senador Firmino (SF-23-X-B-IV-4), Teixeiras (SF-23-X-B-V-1), Tocantins (SF-23-X-D-I-2), Três Rios (SF-23-Z-B-I-2), Ubá (SF-23-X-D-II-1) e Viçosa (SF-23-X-B-V-3). 
A obtenção das cartas topográficas foram realizadas através do download no site do BDGEx (Banco de Dados Geográficos do Exército). O banco de dados do exército foi escolhido à medida que disponibiliza as cartas topográficas no formato raster já georreferenciadas, com as coordenadas geográficas definidas.

A utilização das cartas topográficas como base de dados ocorreu após as mesmas serem preparadas graficamente. Inicialmente retirou-se as informações que constam em suas bordas, como título, escala, orientação, legendas, projeção cartográfica e coordenadas. O recorte foi realizado através do software ArcGis, pela ferramenta de extração por máscara (ArcToolbox -> análise espacial -> extração -> extração por máscara). O recorte através dessa ferramenta funciona da seguinte forma: o software faz a leitura de um arquivo raster (carta topográfica), e utiliza um outro arquivo shapefile como máscara sobre a imagem raster para a realização da extração apenas da área de interesse.

No processo de extração, utilizou-se como máscara o shapefile do Mapa Índice Digital do IBGE. O Mapa Índice foi criado para servir de referência a respeito do mapeamento sistemático existente no país. O shapefile utilizado fornece o encarte entre as cartas topográficas em ambiente analógico, permitindo que este encarte seja utilizado como referência de extração para retirada das bordas das cartas.

$\mathrm{Na}$ continuidade dos procedimentos, as cartas topográficas por já se encontrarem georreferenciadas, apresentavam sistema de referência Datum WGS 1984 (World Geodetic System) e sistema geográfico. Na perspectiva de trabalhar com - mesmo sistema de referência em toda a base de dados, as cartas foram reprojetadas para o sistema SIRGAS 2000 (Sistema de Referência Geocêntrico para as Américas) que é o sistema de referência mais atual e oficial utilizado no Brasil desde fevereiro de 2015. A projeção foi realizada através do ArcGis, pelo do seguinte caminho: ArcToolbox -> Ferramenta de Gerenciamento de Dados -> Projeções e Transformações -> Raster -> Projetar Raster.

Após a projeção, o passo seguinte consistiu em unir todas as cartas topográficas formando um único arquivo raster capaz de abarcar toda a área de interesse. A união das cartas topográficas através da criação de um único mosaico (representado na figura 6) facilitou o manuseio do arquivo. 
Figura 6: Mosaico das cartas topográficas que abarca a área representada pelo mapa antigo. 


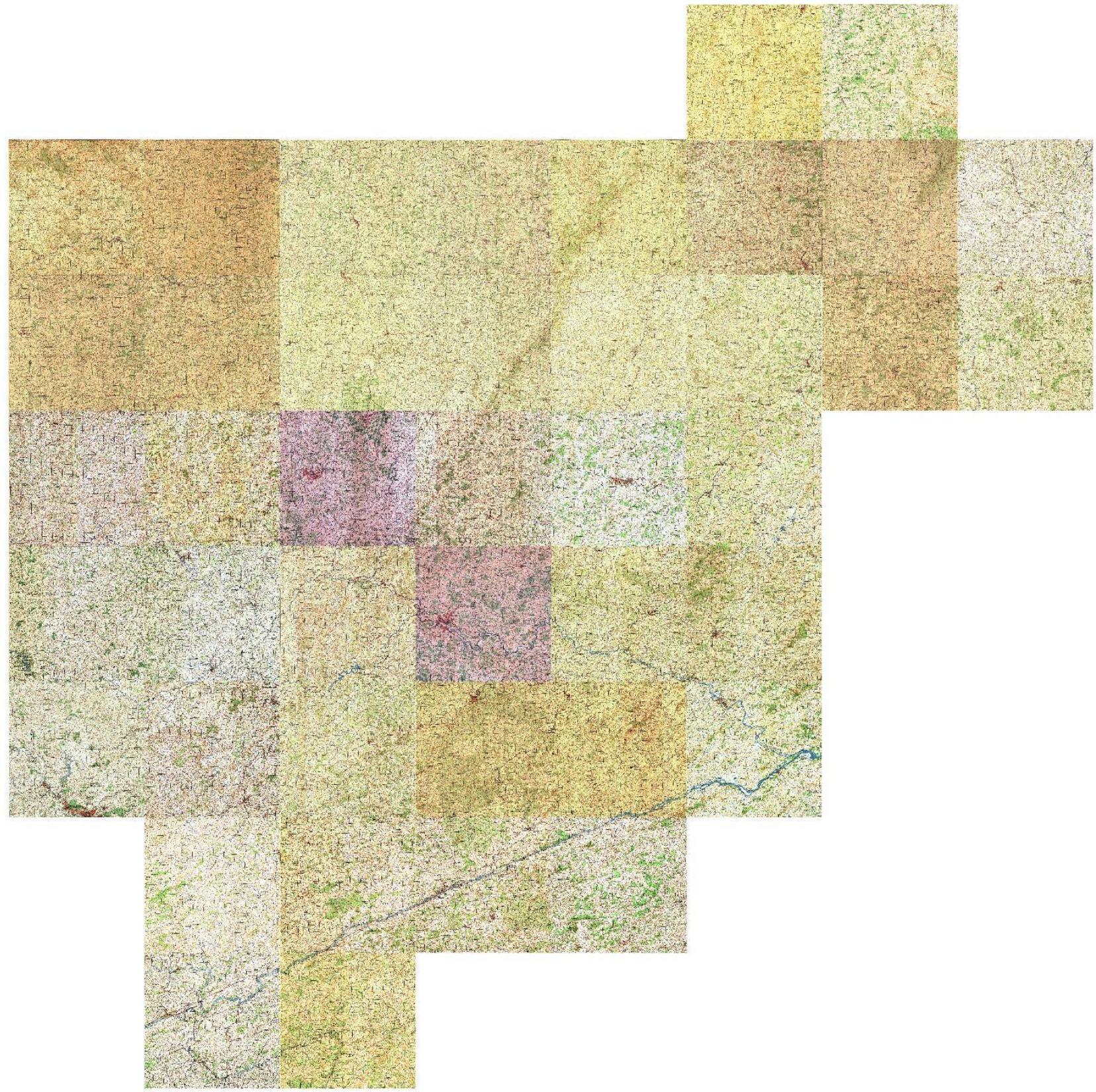

Fonte: Elaborado pelo autor (2021).

A etapa subsequente incidiu em um trabalho investigativo. Inicialmente foram selecionados vilas ou cidades, freguesias, curatos e capelas presentes no mapa de 1847. Posteriormente todas essas localidades foram demarcadas na base cartográfica atual, utilizando como referência as cartas topográficas trabalhadas nas etapas anteriores (como demonstrado na figura 7).

Figura 7: Demarcação do então curato de São Sebastião do Feijão Crú (A) na base cartográfica atual (B). O Curato corresponde atualmente ao município de Leopoldina. 

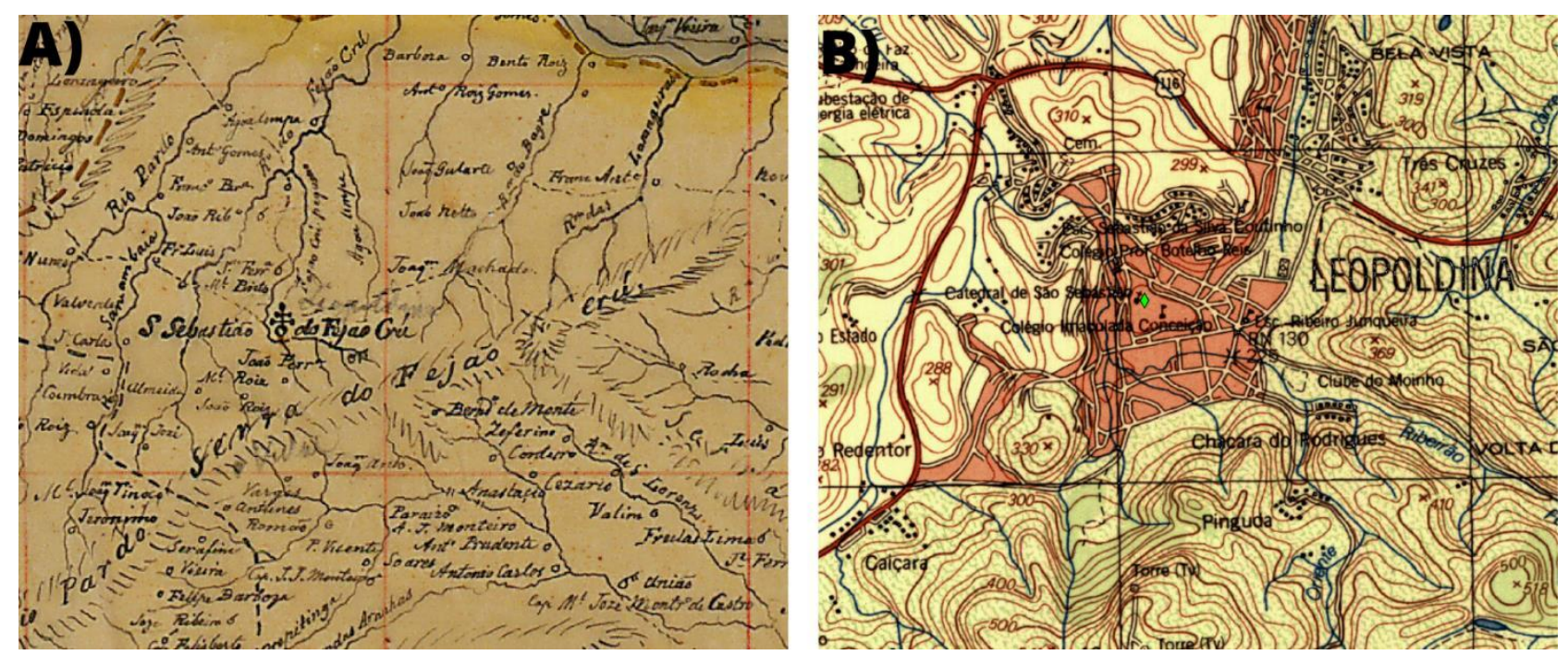

Fonte: Elaborado pelo autor (2021).

A etapa seguinte consistiu no georreferenciamento dos produtos cartográficos. Essa técnica refere-se a associar o mapa a sua coordenada real na superfície terrestre, ou seja, posicioná-lo geograficamente. Nessa etapa adotou-se o procedimento master/slave, onde foi selecionado um mapa da mesma área com coordenadas já definidas para ser referência do mapa histórico. Os pontos de controle adotados para o georreferenciamento do mapa histórico consistiram nas vilas, freguesias, curatos e capelas que somaram 41 pontos de controle. Para a demarcação dos pontos foram selecionadas as igrejas que fundaram essas localidades, tendo em vista que elas conservam a mesma posição geográfica.

Posteriormente foi realizado a vetorização do mapa. Essa técnica consiste em destacar determinada informação de interesse do mapa em detrimento das demais. Por exemplo, uma carta cartográfica contém diversas informações, como estradas, hidrografia, limites municipais e curvas de nível. A vetorização permite que se retire apenas o dado de interesse, podendo trabalhá-lo com outras informações através do geoprocessamento. Nessa perspectiva, com o mapa georreferenciado foi possível vetorizar os limites dos municípios de Visconde do Rio Branco, Rio Pomba e São João Nepomuceno sobre a perspectiva de João José da Silva Theodoro. 


\subsubsection{Ordenamento do território a partir da perspectiva de João José da Silva Theodoro em 1847}

O mapa de João José da Silva Theodoro possibilita analisar o ordenamento territorial a partir de um produto cartográfico. Nessa perspectiva, o mapa histórico de 1847 fomenta esta pesquisa com dados e informações especializadas, que vão além das fontes textuais, permitindo uma compreensão de como o território se organizava no período em questão.

No presente capítulo, deve-se ressaltar que o mapa de 1847, assim como os demais mapas históricos, foram elaborados com técnicas existentes no seu tempo, portanto não apresentam a mesma exatidão que os mapas produzidos atualmente. Logo, é importante deixar claro que a utilização do mapa histórico neste trabalho não tem como objetivo atingir os níveis de precisão definidos pela PEC (Padrão de Exatidão Cartográfica), que é o indicador estatístico atual para considerar um produto cartográfico como um documento de referência. Mas através da metodologia descrita no item 4.2.1, torna possível transformar o mapa histórico em informação localizável e de fácil interpretação para o leitor.

Antes de tratar das informações do mapa também é necessário reforçar que qualquer tentativa de demarcação de limites de municípios anterior a 1938 é impossível ser realizada com acurácia. Esta questão se deve ao fato dos limites se alterarem com uma grande frequência, e também pelo fato de considerar propriedades rurais como divisores do território.

O relatório elaborado por João José da Silva Theodoro sobre a construção do mapa reforça a questão da impossibilidade de demarcar os limites com acurácia. Nele Theodoro esclarece que ao tentar demarcar os limites da província de Minas Gerais com a do Rio de Janeiro, constatou que por não se adotar limites naturais os próprios moradores não sabem a qual província pertencem. Referente as divisas eclesiásticas, Theodoro constatou os mesmos problemas, e ainda manifestou no relatório a questão da sobreposição das demarcações civis e eclesiásticas, já que segundo ele algumas freguesias estendiam seu território além do limite da província de Minas Gerais (THEODORO, 1847).

No relatório Theodoro esclarece sobre as demarcações dos municípios de São João Nepomuceno, Pomba e Presídio que qualquer tentativa de demarcação 
minuciosa das divisas seria inútil, tendo em vista que "o curso tortuoso que estabelecem boa parte das divisas entre os municípios não estão definidos por lugares naturais, ou estáveis" (THEODORO, 1847).

Apesar da dificuldade de estabelecer demarcações precisas para o período, destaca-se como o mapa do Theodoro auxilia a compreender como o território estava organizado.

No processo de trabalhar com o mapa do Theodoro, foram levantados 41 pontos, entre vilas, freguesias, curatos e capelas. Todas as 41 localidades foram identificadas na base de dados formada pelas cartas topográficas georreferenciadas. Esta etapa permitiu posteriormente associar pontos de mesma localização geográfica, e assim georreferenciar o mapa do Theodoro utilizando as 41 localidades como pontos de controle através do método master/slave descrito na metodologia.

O processo de identificação dos pontos comuns exigiu um trabalho investigativo, paisagens naturais como rios e serras auxiliaram a identificar determinados pontos. Outra questão é a alteração dos nomes, o mapa de João José da Silva Theodoro foi realizado em 1847, enquanto as cartas topográficas foram realizadas na década de 70 e 80 , o intervalo superior a cem anos é suficiente para que os nomes próprios dos lugares sejam alterados. Nessa perspectiva, esta parte do trabalho entrou no campo da toponímia.

A realização do estudo da histórica-política administrativa e territorial requer uma atenção a denominação dos lugares. Pode-se imaginar que as denominações dos municípios e dos lugares como conhecemos atualmente estão sujeitas a alterações, logo, quando retomamos a organização política-administrativa e territorial no tempo pretérito, torna necessário conhecer as possíveis mudanças de nomes que ocorreram ao longo do tempo.

O campo que estuda os nomes próprios dos lugares, bem como sua origem e evolução é a toponímia. Desde que o homem descobre um lugar novo e ele passa a ter alguma significação, consequentemente deve-se pensar em um nome. O nome que aquele lugar recebe está atrelado a alguma particularidade do local, revelando um pouco de sua história, portanto a toponímia está atrelada a história e a cultura dos lugares (SEEMAN, 2005).

Os nomes próprios dos lugares no Brasil estão atrelados principalmente a característica hidrográfica ou a vegetação, também relacionado ao nome de uma 
pessoa que representa alguma relevância para aquele lugar, como também uma análise dos topônimos podem evidenciar uma forte relação entre os nomes dos lugares com a religião. Constantes são os nomes dos lugares brasileiros que representam nome do rio, alguma espécie de planta característica daquele local e nome de santos católicos.

A própria vila de São João Batista do Presídio sofreu diversas alterações no seu nome próprio ao longo de sua história. Em um primeiro momento a localidade recebeu o nome de Zona do Rio Xopotó dos Coroados, remetendo aos índios Croatos ou Coroados que ocupavam a região. Quando aldeia, recebeu nome de Aldeia do Xopotó, e no início do século XIX recebeu nome de São João Batista do Presídio. A localidade era cercada por mata fechada, e por isso recebia presos políticos e comuns para cumprir pena, o presídio era aberto, mas fugir daquela localidade era difícil, já outra versão diz que naquela localidade existia uma cadeia, logo, alguma destas versões que justificam o nome do Presídio (PINTO, 2002). Por fim, a localidade recebeu o nome de Rio Branco e Visconde do Rio Branco, uma homenagem ao estadista José Maria da Silva Paranhos, o Visconde do Rio Branco.

O estudo da toponímia fornece também um aparato importante para a cartografia histórica. Uma análise da área a partir das cartas topográficas recentes, comparadas com uma análise do mapa de João José da Silva Theodoro de meados do século XIX apresentará nomes distintos para locais de mesma coordenada geográfica.

Diante disso, através da investigação utilizando as leis provinciais e estaduais que se encontram em meio digital no arquivo público mineiro e na Assembleia Legislativa de Minas Gerais e do livro Enciclopédia dos Municípios de Minas Gerais realizou-se um levantamento das mudanças de toponímia a partir das vilas, freguesias, curatos e capelas. A identificação dos topônimos é importante para entender como os lugares de mesma localização geográfica apresentam nomes distintos ao decorrer do tempo.

Após a identificação foi realizada uma tabela com os 41 lugares selecionados no mapa do Theodoro. A tabela descreve as alterações nos nomes, apresentando o nome antigo e o atual, e também demonstra em qual categoria do ordenamento territorial aquele lugar se enquadrava em 1847, e qual a sua categoria atual. Os 
lugares com asterisco representam somente os pertencentes ao antigo município do Presídio.

Tabela 3: Toponímia e categoria dos pontos demarcados no mapa do Theodoro

\begin{tabular}{|c|c|c|c|}
\hline \multicolumn{2}{|l|}{1847} & \multicolumn{2}{|l|}{ Atual } \\
\hline Nome & Situação & Nome & Situação \\
\hline Presídio de São João Batista* & Município & Visconde do Rio Branco & Município \\
\hline Pomba & Município & Rio Pomba & Município \\
\hline São João Nepomuceno & Município & São João Nepomuceno & Município \\
\hline São Paulo* & Freguesia & Muriaé & Município \\
\hline São Miguel das Almas* & Freguesia & Araponga & Município \\
\hline Santo Antônio de Pádua & Freguesia & Santo Antônio de Pádua & Município \\
\hline Mercês do Pomba & Freguesia & Mercês & Município \\
\hline Santa Rita do Turvo* & Freguesia & Viçosa & Município \\
\hline São Januário de Ubá* & Freguesia & Ubá & Município \\
\hline São Sebastião do Feijão Crú* & Curato & Leopoldina & Município \\
\hline Madre Deus d'Angu & Curato & Angustura & Distrito \\
\hline Santo Antônio da Brota & Capela & Miracema & Município \\
\hline Barra do Bacalhau & Capela & Guaraciaba & Município \\
\hline Bom Jesus do Rio Pardo & Capela & Argirita & Município \\
\hline Santo Antônio & Capela & Porciúncula & Município \\
\hline São Caetano do Xopotó & Capela & Cipotânea & Município \\
\hline Livramento & Capela & Oliveira Fortes & Município \\
\hline São Francisco das Esteiras* & Capela & São Francisco do Glória & Município \\
\hline São Sebastião do Anta* & Capela & Pedra do Anta & Município \\
\hline Bom Jesus do Tabuleiro & Capela & Tabuleiro & Município \\
\hline Conceição do Turvo* & Capela & Senador Firmino & Município \\
\hline Dores do Turvo* & Capela & Dores do Turvo & Município \\
\hline Brás Pires* & Capela & Brás Pires & Município \\
\hline São Sebastião dos Aflitos* & Capela & Ervália & Município \\
\hline São Francisco de Assis* & Capela & Palma & Município \\
\hline Espírito Santo do Piau & Capela & Piau & Município \\
\hline
\end{tabular}




\begin{tabular}{|c|c|c|c|}
\hline Conceição do Rio Novo & Capela & Rio Novo & Município \\
\hline Santa Trindade do Descoberto & Capela & Descoberto & Município \\
\hline São José do Paraopeba* & Capela & Tocantins & Município \\
\hline José do Bagre* & Capela & Guiricema & Município \\
\hline São José do Barroso* & Capela & Paula Cândido & Município \\
\hline Santa Rita da Meia Pataca* & Capela & Cataguases & Município \\
\hline Patrocínio & Capela & Patrocínio do Muriaé & Município \\
\hline Santo Antônio do Porto* & Capela & Astolfo Dutra & Município \\
\hline Glória & Capela & Itamuri & Distrito \\
\hline Conceição & Capela & Conceição da Boa Vista & Distrito \\
\hline Natividade & Capela & Piacatuba & Distrito \\
\hline Dores do Rabicho & Capela & Taruaçu & Distrito \\
\hline Santana do Sapé* & Capela & Guidoval & Município \\
\hline
\end{tabular}

Fonte: Elaborado pelo autor (2021).

Através da análise dos 41 pontos demarcados no mapa de Theodoro foi possível constatar que 36 pontos atualmente evoluíram da categoria que pertenciam em 1847 para município. Reafirmando o surto de criação de novos municípios como já comentado no presente trabalho.

Após a utilização dos pontos de controle para georreferenciar o mapa, foi possível construir um mapa temático (figura 8 ) que represente o ordenamento do território e 1847. No processo de georreferenciamento, ao associar as coordenadas precisas dos pontos das cartas topográficas com o mapa histórico, constatou o deslocamento de alguns pontos, algo já esperado pelo fato de se tratar de um mapa produzido no século XIX. O deslocamento dos pontos variou entre 1 a $2 \mathrm{~cm}$ no mapa, o que representa 5 a $10 \mathrm{~km}$ de deslocamento no terreno em alguns pontos, porém para a escala trabalhada e para os fins de compreensão do ordenamento do território o deslocamento não interfere negativamente. 
Figura 8: Vetorização do Mapa Topográfico dos Municípios do Presídio, Pomba e São João Nepomuceno
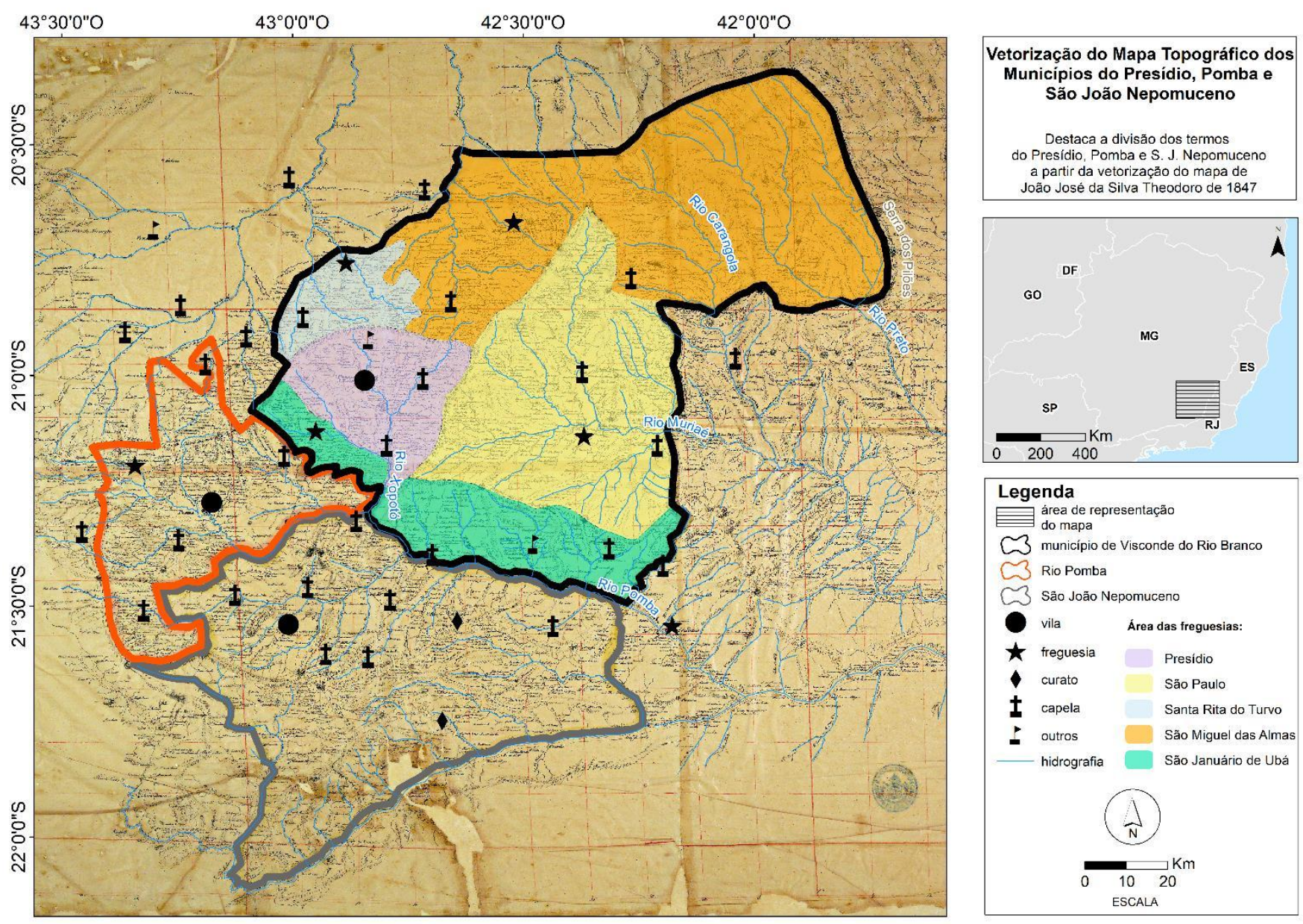

Fonte: Elaborado pelo autor (2020).

O mapa (figura 8) utiliza o mapa de João José da Silva Theodoro georreferenciado com algumas informações essenciais destacadas através da vetorização. O mapa representa três municípios: Presídio, Pomba e São João Nepomuceno, além dos três municípios destacam-se diversas categorias: vilas, freguesias, curatos e capelas.

A partir do mapa é possível constatar o ordenamento do município do Presídio. A vila do Presídio é demarcada com um círculo preto, é na vila que está a câmara, e a extensão territorial subjugada pelo poder das decisões tomadas na câmara se estende aos limites demarcados pela linha de cor preta. 
Além da divisão administrativa, o território também se subdividia na divisão eclesiástica. As freguesias tinham seus territórios reconhecidos pelo Estado, e a sede era responsável por registrar os acontecimentos como nascimentos e óbitos até onde se estendia suas divisas. O município do Presídio quando criado, continha em seu território três freguesias: Arrepiados (Araponga), Santa Rita do Turvo (Viçosa) e a do próprio Presídio (Visconde do Rio Branco), já em 1847, identifica-se duas novas freguesias: São Januário de Ubá (Ubá) e São Paulo (Muriaé), compondo assim a divisão eclesiástica da área de estudo.

No que se refere a divisão eclesiástica, João José da Silva Theodoro esclarece que as freguesias não apresentavam divisas claras, e em vários pontos não são consideradas as paisagens naturais para a delimitação do território. O fato da sede da freguesia não se localizar em uma área central do seu território também chama a atenção de Theodoro. Em seu relatório, sobre a demarcação da freguesia de São Januário de Ubá, Theodoro clarifica que o território da freguesia é extremamente estreito a noroeste, e muito extenso a sudeste, ficando uma grande parcela do território isolada da sede. Além desse fator, sobre o território da freguesia de São Januário de Ubá, chama atenção de Theodoro o fato da divisa ser cortada pelas freguesias do Presídio e de Pomba, que se unem no rio Xopotó (também chamado naquele período de rio do Presídio), portanto o pároco para passar para maior extensão de terras de sua jurisdição, obrigatoriamente deve passar pelas divisas das freguesias de Presídio e Pomba, este fato é facilmente observado na figura 8 (THEODORO, 1847)

A divisa da freguesia de São Miguel das Almas também é descrita por Theodoro em seu relatório. Segundo o relato, os limites da freguesia não são claros para o próprio pároco. Ao Norte, não é clara a divisa com a freguesia de Ponte Nova, já ao sul, sabe-se somente que as divisas cortam os rios da Glória e Carangola, porém impossível definir claramente os limites com a freguesia de São Paulo. O limite da freguesia de São Miguel das Almas também é confuso na divisa com Campos (província do Rio de Janeiro), porém segundo Theodoro, as pessoas que habitavam próximo a cabeceira do Rio Preto pertenciam a freguesia de São Miguel das Almas, sendo aquele local pertencente a então freguesia (THEODORO, 1847).

O município do Presídio de acordo com a demarcação do Theodoro, apresentava uma extensão de aproximadamente $9.814 \mathrm{~km}^{2}$, sobrepondo esta área 
sobre o ordenamento atual dos municípios, nota-se que equivale a área de 50 municípios aproximadamente.

A demarcação do município do Presídio é confusa principalmente na divisa com a província do Rio de Janeiro. A divisa entre as províncias ocorre através de Presídio e Campos, e segundo Theodoro os limites consistem em seguir pela barra do Rio Pomba, os limites não são bem definidos, e seguem até cortar o Rio Muriaé e chegar a serra do Rio Preto. Após este trecho já se encontram os limites do Presídio com a província do Espírito Santo, onde a divisa segue em todo seu trecho pela Serra dos Pilões (THEODORO, 1847).

Figura 9:Extensão territorial do município do Presídio em 1847 sobreposto ao ordenamento atual dos municípios;

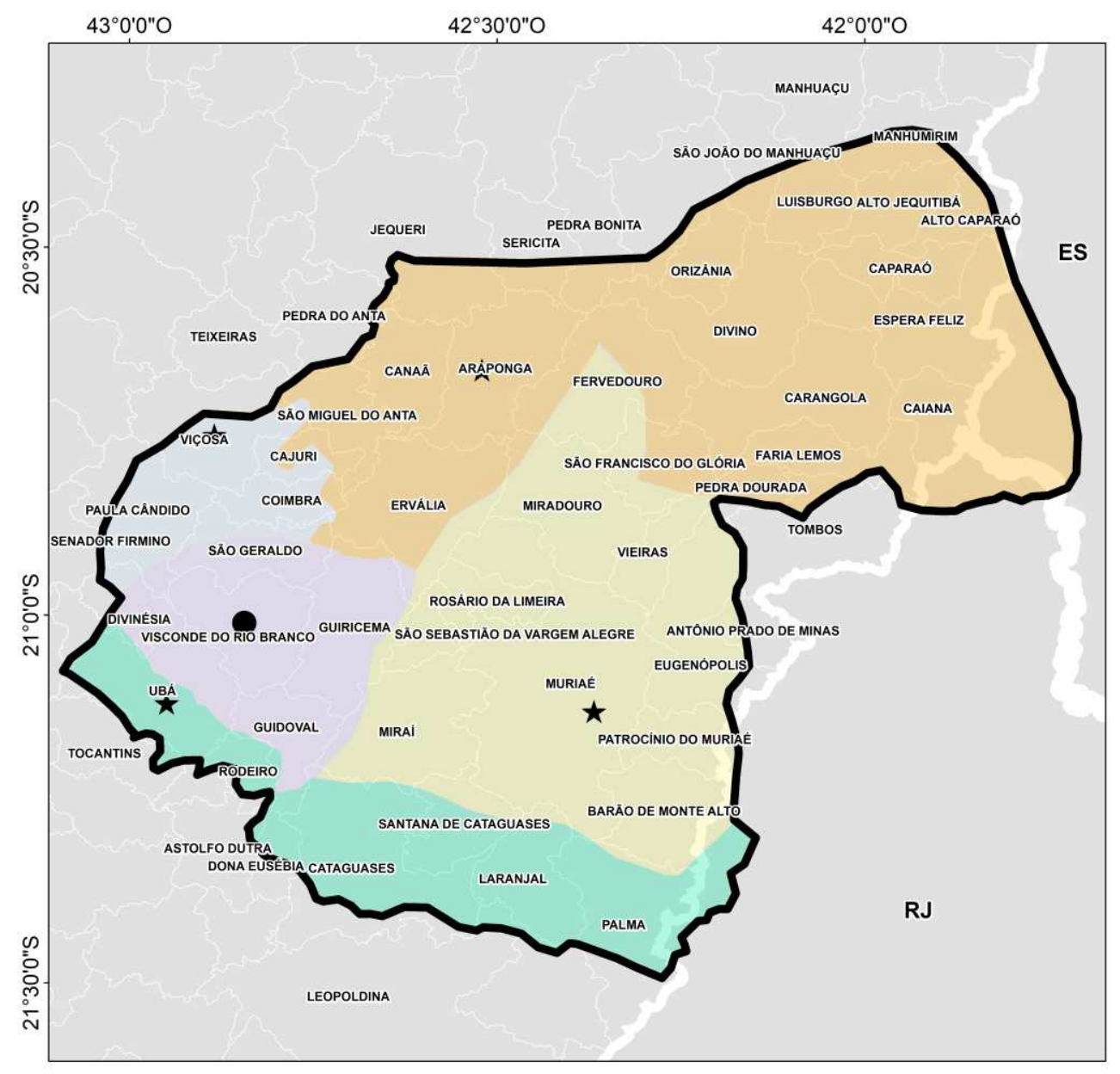

Município do Presídio em 1847 sobreposto ao ordenamento atual dos municípios

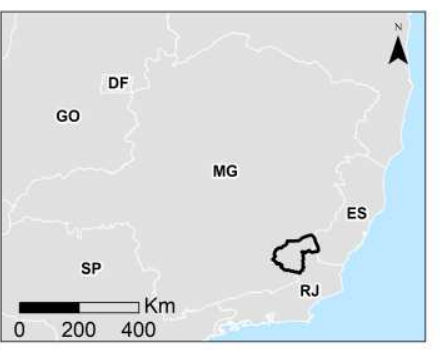

Legenda

3 município de Visconde do Rio Branco

vila

$\downarrow$ freguesia

Area das freguesias:

Presidio

São Paulo

Santa Rita do Turvo

São Miguel das Almas

São Januário de Ubá

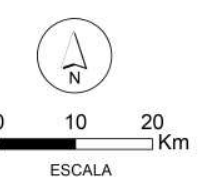

Fonte: Elaborado pelo autor (2021). 


\section{A INVOLUÇÃO CARTOGRÁFICA DA VILA DE SÃO JOÃO BATISTA DO PRESÍDIO}

O presente capítulo representa a evolução cartográfica reversa da Vila de São João Batista do Presídio, associando as divisões políticas-administrativas em um caráter temporal. Comumente estudos temporais tendem a partir do período mais remoto em direção aos acontecimentos mais recentes, mas como o próprio nome do capítulo sinaliza, trata-se de um estudo de involução.

A involução cartográfica parte da divisão político-administrativa atual dos municípios, e segue sua involução, perpassando por diferentes ordenamentos territoriais ao longo do século XX e XIX, até finalmente chegar em 1839, quando todo território representado com seus diversos municípios pertencia unicamente a Vila de São João Batista do Presídio.

No capítulo em questão, adota-se a divisão administrativa do território na perspectiva atual, ou seja, considera-se a divisão do território administrativo exclusivamente a partir do conceito de município, sendo a cidade ou a vila a sede administrativa de um determinado município. Portanto, neste capítulo não será abordado outras instâncias territoriais que foram utilizadas em outros períodos para a divisão do território.

O presente estudo foi inspirado no Projeto de Involução Cartográfica do Estado do Rio de Janeiro, trabalho desenvolvido pelo Laboratório de Cartografia (GeoCart), do Departamento de Geografia da UFRJ. Basicamente, esse projeto teve por finalidade apresentar a evolução cartográfica reversa, ou seja, a involução cartográfica do estado do Rio de Janeiro, representando assim as suas diversas divisões administrativas de caráter temporal. Neste estudo, foi destrinchada a evolução política-administrativa de todo o estado, do período de 2002 (92 municípios), até 1565, data de fundação da cidade do Rio de Janeiro.

A construção dos produtos perpassa pela demarcação das fronteiras municipais, por obstante é importante reforçar o que já foi explicitado no capítulo anterior que somente após 1938 o processo de demarcação das fronteiras torna-se mais preciso, definido segundo linhas geodésicas entre pontos bem identificados ou acompanhamento de acidentes naturais. Outra questão é que as fronteiras municipais apresentavam uma grande fluidez, como aquelas por transferências de propriedades 
de terras que saiam de um município e passavam a pertencer a outro município. Logo, a delimitação dos limites municipais principalmente no século XIX não é totalmente exata.

O presente capítulo e a aplicação da metodologia da involução cartográfica não têm como objetivo delimitar com perfeita acurácia as mudanças nos limites municipais até se constituir a Vila de São João Batista do Presídio, tendo em vista a impossibilidade diante dos fatos elencados no parágrafo anterior para períodos mais antigos. Porém, através do estudo de involução, partindo dos limites atuais para os pretéritos é possível através da combinação de fontes cartográficas e textuais atingir compreensão da dimensão do território das vilas no século XIX, e também possibilita entender como ocorreu a evolução do ordenamento territorial.

Os produtos apresentados nesse capítulo consistem nos Mapas de Involução Cartográfica, estes retratarão a configuração dos limites dos municípios partindo da divisão atual até 1839. Outro produto trata da Genealogia a partir da Vila de São João Batista do Presídio, este produto apresenta as ligações e as origens dos municípios.

O presente capítulo, após concluído o processo de involução da Vila de São João Batista do Presídio, fornece uma base de dados que torna possível compreender a área de vila em 1839, quando desmembrada do Pomba. Os resultados obtidos com a aplicação do processo metodológico de involução cartográfica fornece subsídios para a discussão do processo de evolução dos limites territoriais, além disso o processo de involução demonstra a genealogia completa a partir da vila de São João Batista do Presídio.

Tabela 4: Evolução do número de municípios criados a partir do território da Vila de São João Batista do Presídio;

\begin{tabular}{|ll|}
\hline \multicolumn{2}{|l|}{ Período/Municípios } \\
\hline $1995-2020$ & 49 \\
\hline $1992-1995$ & 45 \\
\hline $1962-1992$ & 44 \\
\hline $1953-1962$ & 31 \\
\hline $1948-1953$ & 22 \\
\hline $1938-1948$ & 18 \\
\hline $1923-1938$ & 10 \\
\hline $1891-1923$ & 8 \\
\hline $1890-1891$ & 7 \\
\hline $1878-1890$ & 6 \\
\hline
\end{tabular}




\begin{tabular}{|cc|}
\hline $1875-1878$ & 5 \\
\hline $1871-1875$ & 4 \\
\hline $1855-1871$ & 3 \\
\hline $1853-1855$ & 2 \\
\hline $1839-1853$ & 1 \\
\hline
\end{tabular}

Fonte: Elaborado pelo autor (2021).

\subsection{Matriz metodológica}

A realização da involução cartográfica da Vila de São João Batista do Presídio foi baseada no estudo de involução do Estado do Rio de Janeiro. Porém é válido ressaltar que devido as distinções da área de estudo, o processo metodológico foi adaptado. Existem tanto para o estado do Rio de Janeiro como principalmente para o município, diversos mapas históricos e antigos para servirem como base comparativa, a grande quantidade de mapas é fruto da importância e evidência histórica daquela região, o que não se repete na área de estudo. Outro ponto a se destacar, é que enquanto o estudo tomado como base faz referência a todo o estado do Rio de Janeiro, e seus atuais noventa e dois municípios, a Vila de São João Batista originou quarenta e nove, permitindo uma análise mais profunda.

Diante do exposto, a metodologia consiste basicamente em pesquisa bibliográfica e levantamento de base de dados cartográfica. O estudo de involução parte inicialmente da divisão política-administrativa atual, e através das pesquisas bibliográficas são "desenhadas" o ordenamento territorial em direção ao tempo pretérito.

O levantamento da divisão política-administrativa atual foi feito através da Malha Municipal Digital de 2018 na escala de 1:250.000 disponibilizada pelo IBGE em formato shapefile. Após a obtenção da divisão política-administrativa atual, utilizou-se o software ArcGis para o processamento dos dados cartográficos que permitiram realizar a representação espacial das mudanças no ordenamento territorial.

O processo de obtenção das informações que retrata as mudanças políticoadministrativas e territorial, baseou-se em fontes bibliográficas. Destacam-se as informações contidas no banco de dados do IBGE referente a história de cada município. Esse banco de dados traz informações resumidas como por exemplo datas de surgimento de distritos, emancipação de municípios e até mesmo mudanças de topônimo. Além das fontes do IBGE, a principal fonte bibliográfica para a pesquisa foi 
o arquivo público mineiro. No banco de dados digital constam as leis mineiras na íntegra de 1835 até 1889. Logo, qualquer alteração legal que ocorreu no estado, encontra-se no banco de dados do arquivo público. Após 1889, as pesquisas referentes as leis que alteraram a divisão administrativa do território se encontram no banco de dados da Assembleia Legislativa de Minas Gerais.

Para a elaboração dos mapas, foi adotado o processo de desconstrução dos limites e construção de limites prévios. Ou seja, os limites foram baseados nos limites atuais, e a partir das informações bibliográficas se inicia o processo de desconstrução do limite atual em direção ao tempo pretérito. Por exemplo, atualmente você tem um município A e outro município $B$ de limites conhecidos, em sua busca bibliográfica evidencia que $A$ e $B$ foram por um determinado período um único município, logo os limites de A e B são unidos para formarem o ordenamento daquele período. Ou seja, basicamente parte-se do limite atual e através da união de polígonos formam-se os limites pretéritos. Porém para formação dos limites considera-se também as informações presentes nas leis provinciais e estaduais.

É importante ressaltar que o processo de involução se diferencia da metodologia adotada pelo IBGE. No mapeamento da divisão municipal feito pelo instituto, a data mais antiga é para o ano de 1872. Além disso, nas notas técnicas dessa divisão consta que "a desconstrução da malha municipal foi realizada a partir da identificação dos municípios que deram origem à divisão municipal mais recente". Ou seja, basicamente a metodologia utilizada desconsidera todas as mudanças anteriores, assumindo apenas a mudança mais recente, o que pode causar algumas controvérsias.

Para compreender a história político-administrativa e territorial de determinado município, é necessário recorrer para além da data de criação do município. A compreensão mais detalhada exige muitas vezes retomar ao período em que ainda era um distrito. Isso ocorre porque as fronteiras entre municípios se remodelavam em grande frequência, e muitos distritos passavam por processos de transferências, pertencendo a diferentes municípios ao longo de sua história.

De uma maneira prática, na origem da divisão municipal mais recente (metodologia adotada pelo IBGE) se determinado município $X$ se desmembrou de $Y$, assume-se que o território de $X$ sempre pertenceu a $Y$. Porém são diversos os casos em que $X$ pertenceu a outro município anteriormente. Para identificar essas 
transferências e realizar uma organização do território com maior autenticidade, a pesquisa a partir das leis provinciais e estaduais e a possibilidade de aprofundar a análise através da formação dos distritos são de grande importância.

A análise mais profunda se remetendo a origem dos distritos, levantou um grupo específico de municípios. Este grupo, foi formado por aqueles municípios que quando distritos passaram por processo de transferência, e originalmente suas terras não pertenciam a Vila de São João Batista do Presídio em 1839.

\subsection{Evolução política a partir da Vila de São João Batista do Presídio}

O marco temporal da criação do território do município de Visconde do Rio Branco foi 1839, ano em que a vila, antes freguesia pertencente a Pomba, se emancipou. Segundo a Lei provincial de número 134 de 16 de março de 1839 em seu artigo primeiro "Ficam elevadas as Vilas as seguintes povoações: A de São João Batista do Presídio, compreendendo no seu município a freguesia do mesmo nome, e as de Santa Rita do Turvo, e de Arrepiados". Naquele período a vila ocupava uma grande área, que nos anos subsequentes originaram outros quarenta e nove municípios. Quando elevada à condição de vila, São João Batista do Presídio detinha aproximadamente uma área de 8.500 quilômetros quadrados como pertencente ao seu município, para se ter uma ideia atualmente o município de Visconde do Rio Branco contém 242 quilômetros quadrados de extensão.

A evolução a partir da Vila de São João Batista do Presídio pode ser diferenciada entre dois momentos. A diferenciação segue o movimento de emancipação que ocorreu de forma geral em todo o estado mineiro. No primeiro momento, referente ao século XIX, constata o desmembramento de uma quantidade pequena de novos municípios. $E$ o segundo momento no século $X X$, ocorre a elevação de uma grande quantidade de municípios por todo o estado.

No século XIX, elevam-se a vila os povoados mais antigos formando municípios de uma grande extensão territorial. Destaca-se nesse período a elevação da Vila de Santa Rita do Turvo, atualmente Viçosa e da Vila de São Paulo do Muriaé, atualmente Muriaé. Os dois novos municípios foram núcleos de criação para outros municípios no final do século XIX e principalmente ao longo do século XX. Das terras do município de Muriaé originaram vinte e cinco municípios, a partir de Viçosa foram criados oito. 
O século XIX, marca também o processo de transferência de sede entre a Vila de São João Batista do Presídio e a Vila de São Januário de Ubá.

No século XX, com o regime republicano consolidado e Minas Gerais como um dos Estados mais relevantes da Federação. O século inicia com a necessidade de estabelecer métodos mais precisos para a criação de novos distritos e municípios, e esses métodos deveriam ser conjunto para todo o Estado. A partir de então iniciaramse revisões conjuntas no quadro das divisões territoriais do Estado em prazos estabelecidos, culminando na criação de muitos municípios ao longo do século (as revisões no quadro territorial durante a república foram detalhadas no capítulo 4.1) (COSTA, 1997).

A partir de agora, neste capítulo serão abordadas as histórias de formação de todos os municípios que suas terras possivelmente já pertenceram em algum momento a Presídio. Para compreender a história de formação de todos os municípios, são utilizadas as leis que respaldaram as alterações na organização político-administrativa. A partir das leis será possível compreender detalhadamente a formação de cada município.

Em 1853, o antes distrito que havia sido criado com a denominação de Arraial de São Januário de Ubá, pela lei provincial de número 209, de 03 de abril 1841, foi elevado a condição de vila, passando a se chamar Vila de São Januário de Ubá. Porém o que ocorreu em 1853 foi uma transferência de sede do Presídio para São Januário de Ubá, logo essa transferência suprimiu a Vila de São João Batista do Presídio para distrito, pertencendo a São Januário de Ubá. Segundo a lei provincial número 654, de 17 de junho de 1853, em seu artigo primeiro "Fica transferida a sede da Vila do Presídio para o Arraial de São Januário de Ubá com a denominação de Vila de São Januário de Ubá. Esta transferência verificar-se-á logo que haja casa suficiente para sessões do júri, e câmara municipal."

O processo de transferência de sede entre os municípios que atualmente são chamados de Ubá e Visconde do Rio Branco não parou em 1853. Segundo a lei provincial número 1573, de 22 de julho de 1868, em seu artigo único: "A sede do município de Ubá, fica transferida para a freguesia do Presídio, tomando a denominação de cidade de São João Batista do Presídio". Ou seja, Ubá volta a condição de distrito enquanto Visconde do Rio Branco é elevada a vila. Em 1871 a situação se inverteu novamente, e somente a partir do ano de 1881 com nova 
elevação de Visconde do Rio Branco a condição de Vila que põe-se fim a troca de sede entre as desde então vilas, através da lei provincial de número 2785 , de 22 de setembro de 1881 que em seu artigo segundo define que "São igualmente criados os seguintes municípios: O de São João Batista do Presídio, composto das freguesias deste nome, elevado à categoria de Vila, a de Bagres e a de São José do Barroso, desmembradas todas do termo de São Januário de Ubá, ficando este novo município pertencendo à comarca de Ubá”. Vale ressaltar que a freguesia de Bagres e de São José do Barroso que também foram desmembradas de Ubá e passaram a pertencer a São João Batista do Presídio, são atualmente os municípios de Guiricema e Paula Cândido respectivamente.

É importante reiterar que o imbróglio político-administrativo entre Ubá e Visconde do Rio Branco iniciado em 1853, não significou alterações no limite do município, apenas a transferência da sede.

A criação do município de Leopoldina se apresentou de forma complexa, tendo em vista que suas terras foram desmembradas de mais de um município. Outro ponto é que os distritos que formaram o então novo município foram transferidos e originaram diversos outros municípios posteriormente. Logo, este trecho explica a formação e a origem não só de Leopoldina, mas também dos municípios Laranjal, Palma e Cataguases.

O município de Leopoldina foi criado em 1854. A lei provincial 666 do mesmo ano estabeleceu em seu artigo segundo que "fica elevada à categoria de vila com a denominação de Vila Leopoldina a freguesia de São Sebastião do Feijão-Crú criada por esta lei". Já o artigo primeiro estabeleceu como freguesia São Sebastião do FeijãoCru do município de Mar de Espanha. Logo percebe-se que a mesma lei que criou a freguesia, a elevou a vila. $O$ artigo terceiro da mesma lei, estabeleceu que o município de Leopoldina "compreenderá os distritos da Vila, Piedade, Rio Pardo, Madre de Deus, São José da Paraíba, Conceição da Boa Vista, Capivara, Laranjal, e Meia Pataca, desmembrados do município de Mar de Espanha e Presídio".

A criação do município de Leopoldina e a formação do seu território ocorreu através de diversos distritos que foram incorporados. Esses distritos foram desmembrados de Presídio e Mar de Espanha, porém a lei provincial não específica os que se desmembraram de Presídio. Posteriormente no século $\mathrm{XX}$, os distritos que compunham o município de Leopoldina se desmembraram e formaram novos 
municípios. Logo, conhecer a origem dos distritos, significa compreender a formação territorial de vários municípios.

Ao retornar um pouco antes da criação de Leopoldina, foi possível identificar os distritos que pertenciam a Presídio. A lei provincial 533, de 1851, em seu artigo nono parágrafo cinco, estabeleceu que os distritos de São Francisco de Assis do Capivara e Nossa Senhora da Conceição do Laranjal fossem transferidos do município do Presídio para o município de Mar de Espanha. Logo, os dois distritos pertenciam ao município do Presídio, antes da transferência para Mar de Espanha em 1851, Leopoldina em 1854 e Cataguases em 1875. Os distritos em questão, atualmente se referem ao município de Palma e Laranjal, e como é possível identificar, quando ainda distritos pertenciam ao território do Presídio antes dos processos de transferências.

O mesmo é válido para o distrito de Santa Rita da Meia Pataca, com ressalva que seu território se enquadrava em dois municípios. A lei provincial 533, de 1851, em seu artigo dezessete insere o limite do então distrito. No texto da lei, fica claro que o distrito de Meia Pataca tinha seus limites perpassando entre a divisa do município do Pomba e do Presídio. Esta esclarece que "a divisa do distrito de Santa Rita da Meia Pataca no Pomba, principia nas águas vertentes, que separam o córrego denominado Pury". Já pelo Presídio, o artigo esclarece que o limite segue "até a ponta da Serra da Onça, entre o Padre Payão, e D. Maria do Guido, pertencendo aquele ao Presídio". Portanto, o distrito se enquadrava nas terras de ambos os municípios.

A lei provincial 534, de 1851, publicada no mesmo dia que a lei anterior, estabeleceu em seu artigo primeiro a elevação do curato de Santa Rita da Meia Pataca a paróquia, compreendendo também os curatos de S. Francisco de Assis do Capivara e Nossa Senhora da Conceição do Laranjal. Ou seja, esta lei criou a freguesia de Santa Rita da Meia Pataca, e seu território enquadrava os três curatos citados.

Apesar deste capítulo trabalhar com a organização administrativa atual (considerando municípios e distritos), retomar a organização de Meia Pataca quando ainda era freguesia ajuda esclarecer a origem dos municípios de interesse deste trabalho. Através dessas informações constata-se que os atuais municípios de Laranjal e Palma (Capivara) pertenciam originalmente ao território do município do Presídio, enquanto Cataguases (Meia Pataca) encontrava-se na divisa entre Presídio e Pomba. 
Os demais distritos que formavam o município de Leopoldina, pertenciam ao município de Mar de Espanha, como explicitado na lei provincial 533, de 1851. Logo, em referência a formação do território a partir da Vila de São João Batista do Presídio, que é o objeto deste trabalho, tem-se as seguintes conclusões: Leopoldina, quando elevado a município em 1854, teve o seu território formado parcialmente por terras do Presídio; os distritos que se desmembraram do Presídio para formar o novo município em 1854, atualmente se referem aos municípios de Laranjal, Palma e Cataguases; por fim, Cataguases quando ainda distrito, seu território pertencia a Pomba e Presídio.

No prosseguimento da análise de formação dos municípios, o município seguinte a ser analisado foi Viçosa. O município foi criado no ano de 1871 quando elevado a vila. Naquele ano a vila ao invés de Viçosa ainda era denominada Santa Rita do Turvo. Quando foi criada, teve seu território desmembrado do município de Ubá, tendo em vista que neste ano Ubá era vila, enquanto Visconde do Rio Branco era distrito pertencente a Ubá, fruto do processo de transferência de sede relatado no parágrafo anterior. Foi desmembrada uma área equivalente a aproximadamente 1600 quilômetros quadrados que atualmente conta com nove municípios. Logo, ao analisar a formação do município de Viçosa, será também abordado a formação dos municípios de Cajuri, Ervália, Teixeiras, Coimbra, São Miguel do Anta, Pedra do Anta, Canaã e Araponga.

A partir de Viçosa no século $X X$ surgiram diretamente cinco municípios, além de três desmembramentos posteriormente de seus antes distritos. Entre os cinco, são eles: Cajuri em 1926, Ervália em 1938, Teixeiras em 1938, Coimbra em 1948, e São Miguel do Anta em 1953. Dentre os novos municípios emancipados de Viçosa, três deles foram desmembrados para originar um outro município. Ervália teve o seu distrito de Araponga e Estevão Araújo desmembrados, juntos eles formaram o novo município de Araponga em 1962. Também no ano 1962 o município de Teixeiras viu a elevação do seu antes distrito de Pedra do Anta para à condição de município. Por fim, o município de São Miguel do Anta em 1962 perdeu o distrito de Canaã, elevado à condição de município no mesmo ano.

Os municípios que surgiram a partir de Viçosa inicialmente pertenciam ao território de Ubá, quanto distritos. Ervália já existia como distrito, e após a criação de Viçosa em 1871 ainda permaneceu como distrito de Ubá. A mudança ocorreu no ano de 1891, pela lei estadual de número 2, publicada em 14 de setembro, quando o 
distrito foi transferido para Viçosa, naquele período ainda denominava-se São Sebastião do Erval. Coimbra teve seu povoado elevado a distrito pela lei número 1103 de 16 de outubro de 1861, em seu artigo primeiro. Em 1871 com Viçosa elevada à condição de Vila o distrito passou a pertencê-la.

O município de São Miguel do Anta apesar de desmembrado de Viçosa originalmente, seu território não fazia parte da Vila de São João Batista. Quando o distrito de São Miguel do Anta foi criado em 1857, pela lei provincial de número 818, este pertencia a Vila de Ponte Nova como consta em artigo primeiro e parágrafo segundo: "Ficam elevados a Distrito de Paz: O Curato de São Miguel da Freguesia do Anta”. Porém em 1871 o distrito de São Miguel do Anta foi desmembrado e passou a pertencer ao município de Viçosa como consta na lei 1817, de 30 de setembro em seu artigo segundo, e descreve que São Miguel do Anta passou a pertencer a Santa Rita do Turvo, atualmente Viçosa. Vale ressaltar que o artigo primeiro também da lei 1817 é o que eleva a freguesia de Santa Rita do Turvo a condição de vila, ou seja, assim que Viçosa se desmembrou de Ubá o distrito de São Miguel do Anta foi transferido.

A especificação anterior esclarece que São Miguel do Anta é um território originário da Vila de Ponte Nova, e a considerar a divisão municipal mais recente (metodologia adotada pelo IBGE) equivocadamente a área seria considerada como pertencente a antiga Vila de São João Batista do Presídio. O mesmo também é válido para Canaã, desmembrado de São Miguel do Anta em 1962, que também territorialmente estava ligado a Ponte Nova até 30 de setembro de 1871.

A partir do município de Ubá, ocorreu apenas o desmembramento de Viçosa no século XIX. Já no século $X X$, cinco municípios foram desmembrados a partir de Ubá: Guidoval em 1948, Tocantins no mesmo ano, Rodeiro e Divinésia em 1962 e Senador Firmino em 1938. Além destes, outros dois surgiram a partir do município de Senador Firmino: Dores do Turvo e Brás Pires, ambos em 1953.

O distrito de São José do Paraopeba foi criado de acordo com a lei provincial número 1492, de 13 de julho de 1868, subordinado a Vila de Ubá. De 1868 até 1871 passou a pertencer a Visconde do Rio Branco, devido ao processo de troca de sede. Por fim, São José do Paraopeba que consisti no município de Tocantins seguiu como distrito de Ubá até 1948, quando foi publicada a lei de número 336, de 27 de dezembro desmembrando o então distrito de Ubá. O mesmo ocorreu com o antigo distrito de Santana do Sapé, criado em 1856 pela lei provincial de número 758, publicada em 02 
de maio daquele ano. Santana do Sapé atualmente corresponde ao município de Guidoval e permaneceu como distrito de Ubá até 1948, ano em que foi elevado a município.

Em 1911, através da lei estadual 556 de 30 de agosto foi criado o distrito de Divino, pertencente ao município de Ubá, junto dele e também a partir da mesma lei foi criado outro distrito, São Sebastião da Boa Esperança do Rodeiro. Em 1962, através da lei estadual 2764 de 30 de dezembro que ambos os distritos foram elevados a município, essa mudança culminou também em alteração do nome, passando Divino a se chamar Divinésia, e Boa Esperança do Rodeiro a somente Rodeiro.

O município de Senador Firmino se desmembrou de Ubá em 1938. E deste em 1953 desmembraram-se dois municípios: Dores do Turvo e Brás Pires. Porém o processo de formação dos três municípios demonstra que seus territórios originalmente pertenciam ao município de Piranga, e não de São João Batista do Presídio como uma divisão municipal mais recente levaria a crer.

Em 1841, através da lei provincial 202 de 1 de abril, o então distrito do Piranga foi elevado à condição de vila, em seu artigo primeiro e parágrafo primeiro estabelecia que "Ficam elevadas a vilas as seguintes povoações: A do Piranga com o título de Vila da Piranga - desmembrada do município e da cidade de Mariana". Porém em 1865 através da lei $n^{\circ}$ provincial $n^{\circ} 1249$, de 17 de novembro, a vila é extinta, sendo seu território anexado novamente ao município de Mariana. Em 1868 finalmente Piranga é elevada novamente a condição de vila pela lei n 1537, de 2-07-1868. Através dessa mesma lei o então distrito de Conceição do Turvo que também pertencia a Mariana passou a fazer parte agora da Vila do Piranga, tornando-se distrito desta.

O antigo distrito de Conceição do Turvo refere-se atualmente ao município de Senador Firmino. O distrito foi criado em 1865 pela lei provincial 1262, publicada em 19 de dezembro. Através do parágrafo anterior, constata-se que o distrito de Conceição do Turvo pertencia a Mariana, e posteriormente transferiu-se para Piranga em 1868, quando este foi elevado a vila. O distrito de Conceição do Turvo continuou como distrito de Piranga até o ano de 1923, quando através da lei estadual 843 de 7 de setembro, o distrito de Conceição do Turvo foi transferido para o município de Ubá. Portanto o município de Senador Firmino, pela ótica territorial considerando como 
ponto de partida da antiga Vila de São João Batista do Presídio não deveria se enquadrar como originário daquelas terras. Em 1839 quando surge a Vila de São João Batista do Presídio, onde se encontra Senador Firmino atualmente eram terras pertencentes a Mariana, e seguiram pertencendo até o ano de 1868. E posteriormente passaram a pertencer a Piranga. Logo, como Senador Firmino foi desmembrado de Ubá em 1938 pela lei estadual número 148 de 17 de dezembro, não aprofundar no processo de formação do seu território poderia levar ao equívoco de considerar suas terras como pertencentes a Presídio.

Os municípios desmembrados de Senador Firmino: Dores do Turvo e Brás Pires, também se enquadram na mesma situação relatada no parágrafo anterior. Dores do Turvo se remete ao surgimento do seu povoado em 1783 com a construção da primeira capela. O distrito, porém, foi criado somente em 1850 através da lei provincial 471 de 1 de julho, além de distrito de paz, naquele mesmo ano também se tornou freguesia. O distrito era subordinado a Piranga até a publicação da lei estadual número 23 de 25 de maio de 1892, que estabeleceu a transferência do distrito para o novo município denominado Alto Rio Doce (município criado também em 1892, desmembrado de Piranga). Dores do Turvo permaneceu como distrito de Alto Rio Doce até o ano 1938, porém naquele ano com a elevação de Senador Firmino à condição de município, o distrito de Dores do Turvo passou a lhe pertencer. Tal fato pode ser confirmado na lei estadual 148 de 17 de dezembro, a mesma lei que elevou Senador Firmino à condição de município. Por fim, Dores do Turvo nunca apresentou vínculo com São João Batista do Presídio ou até mesmo Ubá, tendo em vista que pertenceu a Piranga e Alto Rio Doce até 1938, e somente quando Senador Firmino tornou-se município desmembrando-se de Ubá que Dores do Turvo se torna distrito de Senador Firmino.

A evolução histórica do município de Brás Pires, se remete a criação do povoado por Brás Pires Farinho. O povoado foi elevado a distrito em 1891 pela lei estadual de número 2 de 14 de setembro, o distrito foi criado pertencente a Vila do Piranga, na qual permaneceu até o ano de 1938. Através do decreto e lei estadual 148 de 17 de dezembro, o distrito foi transferido para Senador Firmino, permaneceu como distrito até 1953 quando foi elevado a município pela lei estadual 1039 de 12 de dezembro daquele ano. $O$ atual município também não apresenta vínculo territorial ou administrativo com a vila de São João Batista do Presídio. 
A partir de Ubá também ocorreu o desmembramento de Cataguases, de acordo com a lei da Assembleia mineira 2180 de 25 de novembro de 1875. Cataguases aparece três vezes na figura 1, tanto se desmembrando de Ubá, Muriaé e Leopoldina, isso se deve ao fato do município quando criado ter suas terras formadas a partir do município de Ubá, Muriaé e Leopoldina. Por agora serão tratados os municípios que se originaram nas terras desmembradas de Ubá.

A partir de Cataguases emancipou-se em 1938 o município de Astolfo Dutra de acordo com a lei estadual número 148 de 17 de dezembro. Porém Astolfo Dutra, o antigo distrito de Porto de Santo Antônio, era subordinado a Pomba até o ano de 1888. Com a lei provincial 3589 de 28 de agosto, o distrito foi desmembrado de Pomba para ser anexado a Cataguases:

Transfere do termo do Pomba para o de Cataguazes a freguesia do Porto de Santo Antônio, da qual fica desmembrada e incorporada à do Guarany a parte compreendida entre a serra dos Pereiras, nas vertentes do ribeirão Diamante e a confluência do Rio Paraopeba com o Pomba (MINAS GERAIS, 1889, p. 204).

Ao retomar ao início do processo de formação de Astolfo Dutra, fica evidente que onde atualmente encontra-se o município, se estendia os limites de Pomba. A lei provincial 2035 de 1873 estabelece que "fica criada a freguesia de Porto de Santo Antônio, do município de Pomba". Logo, é possível constatar que Astolfo Dutra pertenceu a Pomba, sendo posteriormente transferido para Cataguases.

A mesma constatação também é válida para o município de Dona Eusébia, as terras passaram a pertencer ao distrito de Astolfo Dutra em 1938 quando Astolfo Dutra se tornou município, anteriormente pertenciam a Cataguases. Em 1962 o distrito foi elevado à condição de município, desmembrando-se de Astolfo Dutra de acordo com a lei estadual número 2764 de 30 de dezembro daquele ano. Como Astolfo Dutra, inicialmente seu território estava ligado a Pomba.

A partir de São João Batista do Presídio, além do desmembramento dos municípios de Ubá e Muriaé no século XIX, nos anos posteriores já no século $X X$, ocorreu o desmembramento de três dos seus então distritos: Guiricema, São Geraldo e Paula Cândido.

O município de Guricema surgiu como povoado em 1825 com a construção da sua primeira capela. No ano de 1838 já se configurava como arraial, denominado 
Arraial do Bagre. Em 1872, através da lei provincial 1899 de 19 de julho daquele ano o distrito é criado, subordinado a Visconde do Rio Branco. Já em 1938, com a denominação de Guricema é elevado a condição de município, desmembrando-se de Visconde do Rio Branco, como especificado pelo decreto estadual 148 de 17 de março de 1938.

O município de São Geraldo surgiu a partir da criação da estação da linha férrea de São Geraldo, fazendo crescer a população daquela área e culminando com a construção da primeira capela em 1882 e consequentemente originando o seu povoado. Um ano depois, em 1883 criou-se o distrito com denominação de São Geraldo de acordo com a lei provincial número 3161 de 18 de outubro. Em 1948, através da lei 336 e do seu artigo 80, de 27 de dezembro elevou-se o distrito a condição de município (FERREIRA, 1959).

O município de Paula Cândido surgiu como povoado de São José do Barroso, como distrito pertenceu a Viçosa, como consta na lei provincial 202 de 1841 . No ano de 1854 o distrito foi transferido para o município de São Januário de Ubá. O distrito foi elevado a condição de paróquia de acordo com o artigo segundo da lei 1682 de 21 de setembro, no ano de 1870. Em 1891 através da lei estadual número 2 de 14 de setembro foi confirmada a criação do seu distrito pertencendo ao município de Visconde do Rio Branco, e por fim pelo decreto estadual número 148 o distrito é elevado a condição de município, já denominando-se Paula Cândido (FERREIRA, 1959).

A partir de agora voltaremos um pouco no tempo para tratar dos processos de desmembramento e criação de municípios a partir da Vila de São Paulo do Muriaé, a primeira a se desmembrar de São João Batista do Presídio ainda no ano de 1855 . O distrito foi criado em 1852, pela lei provincial de número 605 pertencendo a São João Batista do Presídio, essa configuração permaneceu até 1855, porém a lei número 724 de 16 de maio de 1855 estabeleceu que "fica elevada à categoria de Vila a Freguesia de São Paulo do Muriaé com a mesma denominação". A partir da publicação da lei 724 foi desmembrado da vila de São João Batista do Presídio uma área de aproximadamente 5 mil quilômetros quadrados, nessa área atualmente se encontram vinte e cinco municípios, que foram se desmembrando a partir da antiga vila de São Paulo do Muriaé. 
A partir de Muriaé (antiga São Paulo do Muriaé) foram criadas outras seis vilas: Carangola em 1878 pela lei provincial de número 2500, Eugenópolis pelo decreto estadual de número 413 de 09 de março de 1891 e Cataguases em 1875 pela lei provincial 2180 , de 25 de novembro daquele ano. $E$ já no século $X X$ outros três distritos foram elevados a condição de vila se desmembrando de Muriaé: Miradouro em 1938, Patrocínio do Muriaé em 1953 e Rosário da Limeira em 1995 através das respectivas leis: lei estadual 148, de 17 de dezembro de 1938, lei estadual 1039, de 12 de dezembro de 1953 e lei estadual 10703 de 21 de dezembro de 1995.

Dentre as novas vilas emancipadas a partir de Muriaé, quatro delas originaram pelo menos um outro município. A partir de Eugenópolis ocorreu a elevação do seu antigo distrito de Antônio Prado de Minas para município em 1962 de acordo com a lei estadual 2764, de 30 de dezembro daquele ano. Já Miradouro, de acordo com a lei estadual 1039 de 12 de dezembro de 1953, teve seus distritos denominados de Vieiras e Santo Antônio do Glória desmembrados para originar um novo município denominado Vieiras. Já Carangola e Cataguases apresentaram a partir de seu território um desmembramento complexo, originando diversos novos municípios nos anos subsequentes.

A vila de Cataguases se desmembrou de Muriaé em 1875, de acordo com a lei da Assembleia mineira 2180 de 25 de novembro de 1875. De acordo com a figura 5, Cataguases aparece tanto no desmembramento a partir de Muriaé, quanto no desmembramento a partir de Ubá, tal fato se deve ao processo de criação da vila de Cataguases, já que quando elevada à condição de vila a formação do seu território aconteceu a partir do desmembramento de áreas do município de Leopoldina, Muriaé e Ubá.

No momento serão elencadas as vilas que se originaram a partir do território desmembrado de Muriaé para formar Cataguases. Em 1923, de acordo com a lei estadual 843 de 7 de setembro daquele ano, o então distrito de Miraí foi elevado à condição de vila, posteriormente em 1995, de acordo com a lei estadual 12030, o distrito de Miraí denominado São Sebastião da Vargem Alegre foi elevado à condição de município.

No ano de 1890 foi criada a Vila de São Francisco de Assis de Capivara, atualmente Palma. A vila foi desmembrada de Cataguases a partir da lei estadual 297 de 23 de dezembro daquele ano. Palma originou posteriormente em 1962 o município 
de Barão do Monte Alto de acordo com a lei estadual 2764 de 30 de dezembro daquele ano. Barão do Monte Alto surgiu a partir do desmembramento e união de três antigos distritos de Palma: Cachoeira Alegre, Silveira Carvalho e Barão de Monte Alto.

A partir de Cataguases surgiu também o município de Santana de Cataguases, o distrito que pertencia a Cataguases foi elevado a município pela lei estadual 2764 de 30 de dezembro de 1962.

O município de Laranjal foi elevado à esta condição em 1938, desmembrado de Cataguases de acordo com a lei estadual 148 de 17 de dezembro daquele ano. $O$ atual município, segundo a Lei provincial 533 de 10 de outubro de 1851 consistia em um distrito de Presídio. Porém em 1854, com a criação do município de Leopoldina, o distrito passou a incorporar o novo município. E já em 1875 foi incorporado ao novo município de Cataguases. Essas duas transferências são identificadas na Lei provincial 666, de 27 de abril de 1854 e na lei 2180, de 25 de novembro de 1875, respectivamente.

Por fim, o atual município de Itamarati de Minas surgiu de Cataguases. O distrito foi criado através do Decreto Estadual n 405, de 6 de março de 1891, após onze anos da solicitação de fazendeiros da região para o Governo do Estado. O distrito foi criado dentro do território do município de Cataguases. O distrito somente foi elevado a município em 1962.

A respeito da Vila de Carangola, esta denominava-se vila de Santa Luzia do Carangola e apresentava uma grande extensão territorial. A partir de seu território foram criados seis novos municípios, desconsiderando os que surgiram posteriormente a esses seis municípios. Entre os municípios criados a partir de Carangola estão: Tombos, Divino, Espera Feliz, Faria Lemos, São Francisco do Glória e Fervedouro.

Divino em 1938 passou pelo processo de emancipação do seu distrito, de acordo com a lei estadual 148 de 17 de dezembro daquele ano, o distrito passou à condição de município. A lei também esclareceu que o distrito de Arrozal passou a pertencer a Divino, sendo desmembrado de Carangola. Posteriormente o antigo distrito de Arrozal foi elevado a condição de município de acordo com a lei estadual 12030 de 21 de dezembro de 1995 denominando-se Orizânia. O antes distrito de Orizânia que denominava-se Alto Carangola, passou a se chamar Arrozal em 1938 e somente 1943 tomou o nome atual. 
O município de Espera Feliz se emancipou de Carangola em 1938 de acordo com a lei estadual 148 de 17 de dezembro. A partir de Espera Feliz originaram-se novos municípios, porém ainda quando era distrito pertencente a Carangola perdeu parte de seu território, desmembrado para a criação de um novo distrito, o de São José do Rio Preto em 1923 como consta na lei estadual 843 de 7 de setembro. Posteriormente São José do Rio Preto voltou a pertencer a Espera Feliz, em 1938, no ano em que o município de Espera Feliz se emancipou de Carangola. São José do Rio Preto passou a se chamar Caiana e em 1962 foi elevado a condição de município, deixando de pertencer a Espera Feliz, de acordo com a lei estadual 2764 de 30 de dezembro daquele ano. O município de Espera Feliz também no ano 1962 perdeu parte de seu território para a criação de um outro município: Caparaó, de acordo com a lei 2764 de 30 de dezembro. Finalmente, a então última mudança política administrativa foi a criação do município Alto do Caparaó em 1995, o antes distrito de Caparaó foi elevado a condição de município de acordo com a lei estadual 12030 de 21 de dezembro.

O município de Tombos quando distrito se denominava Tombos de Carangola em referência ao município que pertencia, porém foi desmembrado de Carangola em 1923, de acordo com a lei estadual 843 de 7 de setembro daquele ano. Já em 1938, o município de Tombos com terras do seu próprio município e de Faria Lemos origina um novo distrito, o de Pedra Dourada, como é possível conferir na lei estadual 148 de 17 de dezembro de 1938. O distrito de Pedra Dourada seguiu pertencendo a Tombos até 1962, quando o distrito foi elevado a município pela lei estadual 2764 de 30 de dezembro daquele mesmo ano.

Os demais municípios a se desmembrarem de Carangola foram Faria Lemos e São Francisco do Glória, através da Lei estadual 1039 de 12 de dezembro de 1953. Posteriormente Fervedouro também foi criado a partir de Carangola através da Lei estadual 10704, de 27 de abril de 1992.

Os municípios de Espera Feliz, Caparaó, Caiana e Alto do Caparaó ao se aprofundar na evolução político-administrativa e territorial destes municípios, fica claro que seus territórios não pertenciam ao município de São João Batista do Presídio. O território de Espera Feliz e consequentemente dos municípios que surgiram e foram desmembrados a partir dele, pertenciam a Vila de Campos (atual Campos dos Goytacazes), inserida na província do Rio de Janeiro. Logo, quando foi criada a Vila 
de São João Batista do Presídio em 1839, esta área inicialmente não a pertencia. Ferreira (1959), esclarece as alterações:

Todo o território que hoje integra o município de Espera Feliz, pertenceu à Vila de Campos, da província do Rio de Janeiro. Só muitos anos depois, passou aquele território a integrar, primeiramente, a freguesia de N. Sa. de Tombos, comarca de Presídio, hoje, Visconde do Rio Branco; depois, a Vila de Ubá e ao termo de São Paulo do Muriaé, para, por último, se transformar em Freguesia de Santa Luzia do Carangola. (FERREIRA, 1959, p.90).

O atual município de Orizânia ao considerar a divisão municipal mais recente, pode aparentar equivocadamente que a extensão territorial onde atualmente se encontra Orizânia pertencia a São João Batista do Presídio quando ainda era um povoado, estava submetido a Manhuaçu, inclusive quando elevado à condição de distrito em 1890 pela Lei estadual 195, seu território continuou pertencendo a Manhuaçu. Somente em 1891, um ano após virar distrito que este foi transferido para Carangola.

Após a análise do quadro evolutivo a partir da Vila de São João Batista do Presídio foi possível representar a genealogia a partir da vila de São João Batista do Presídio e todos os municípios originados a partir de sua antiga extensão territorial. Logo a genealogia contempla todas as divisões que deram origem a divisão políticaadministrativa dos municípios como conhecemos atualmente.

A genealogia consta com alguns municípios destacados com asterisco. Tal demarcação é para evidenciar os municípios que em um determinado momento do seu processo de formação suas terras não pertenciam a São João Batista do Presídio. Ou seja, essas localidades foram anexadas após 1839. Os casos foram especificados ao longo do texto. 
Figura 10: Genealogia a partir da Vila de São João Batista do Presídio

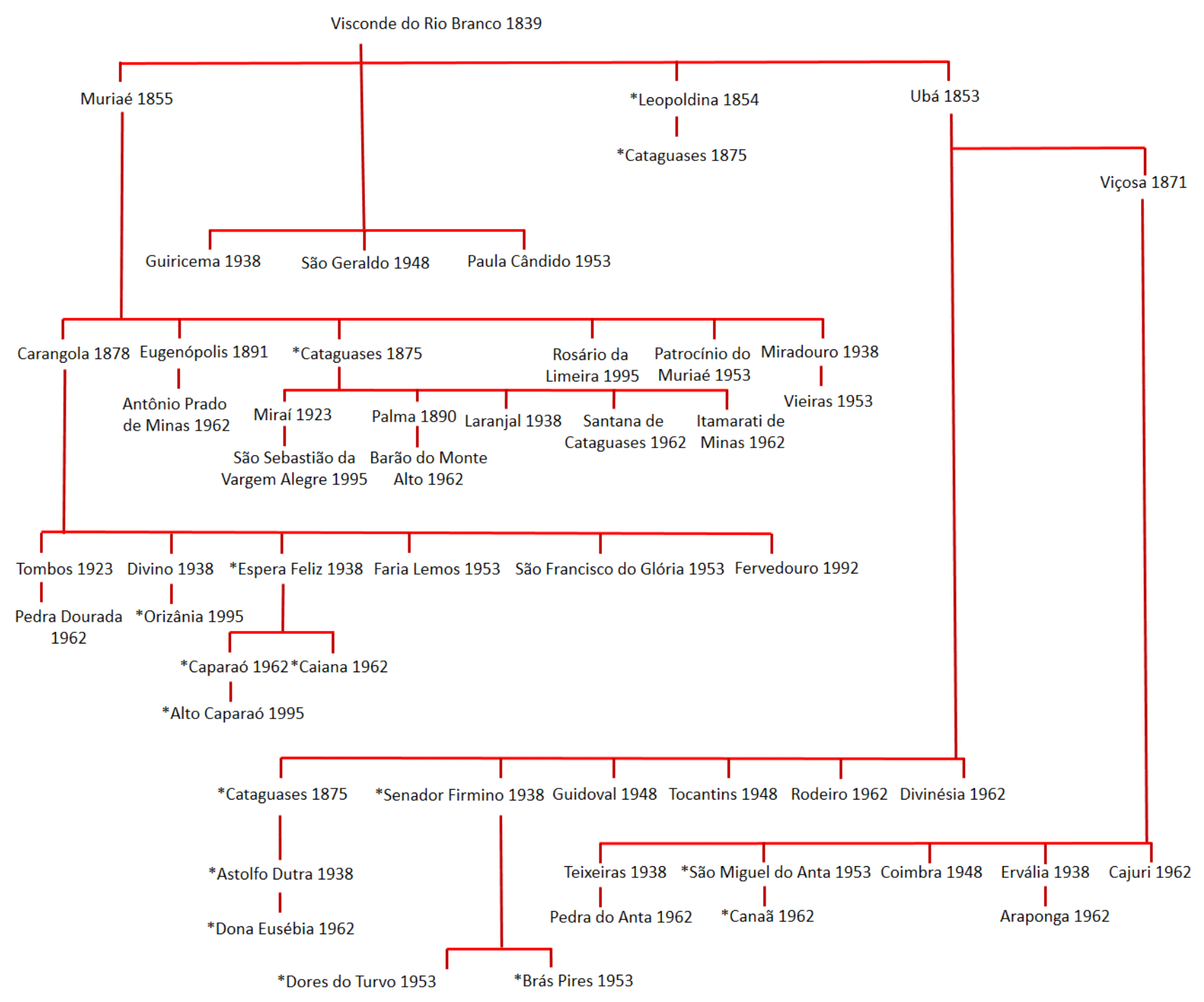

Fonte: Elaborado pelo autor (2021).

\subsection{Involução política-administrativa e territorial}

A partir da base de dados dos atuais limites municipais em conjunto com as fontes bibliográficas: leis provinciais, leis estaduais e IBGE estabeleceu-se as diversas divisões políticas municipais, criando uma base de informações que perpassa pela divisão atual até a Vila de São João Batista do Presídio em 1839.

O foco foi utilizar a configuração atual dos municípios, e combiná-las com as fontes textuais levantadas para gerar uma aproximada configuração dos municípios em períodos anteriores. Reiterando que o objetivo final é projetar o limite do território do município da Vila de São João Batista do Presídio. 
A primeira divisão político-administrativa a ser realizada foi a de 1995, representando a configuração atual. Os municípios adicionados foram aqueles que se formaram direta ou indiretamente a partir de São João Batista do Presídio. Logo, a primeira divisão consta com os municípios que aparecem na genealogia do capítulo anterior. A única exceção é Leopoldina, pois o território desmembrado de Presídio para formá-lo são os referentes a Cataguases, Laranjal e Palma (como especificado no item 5.2).

Figura 11: Divisão territorial em 1995

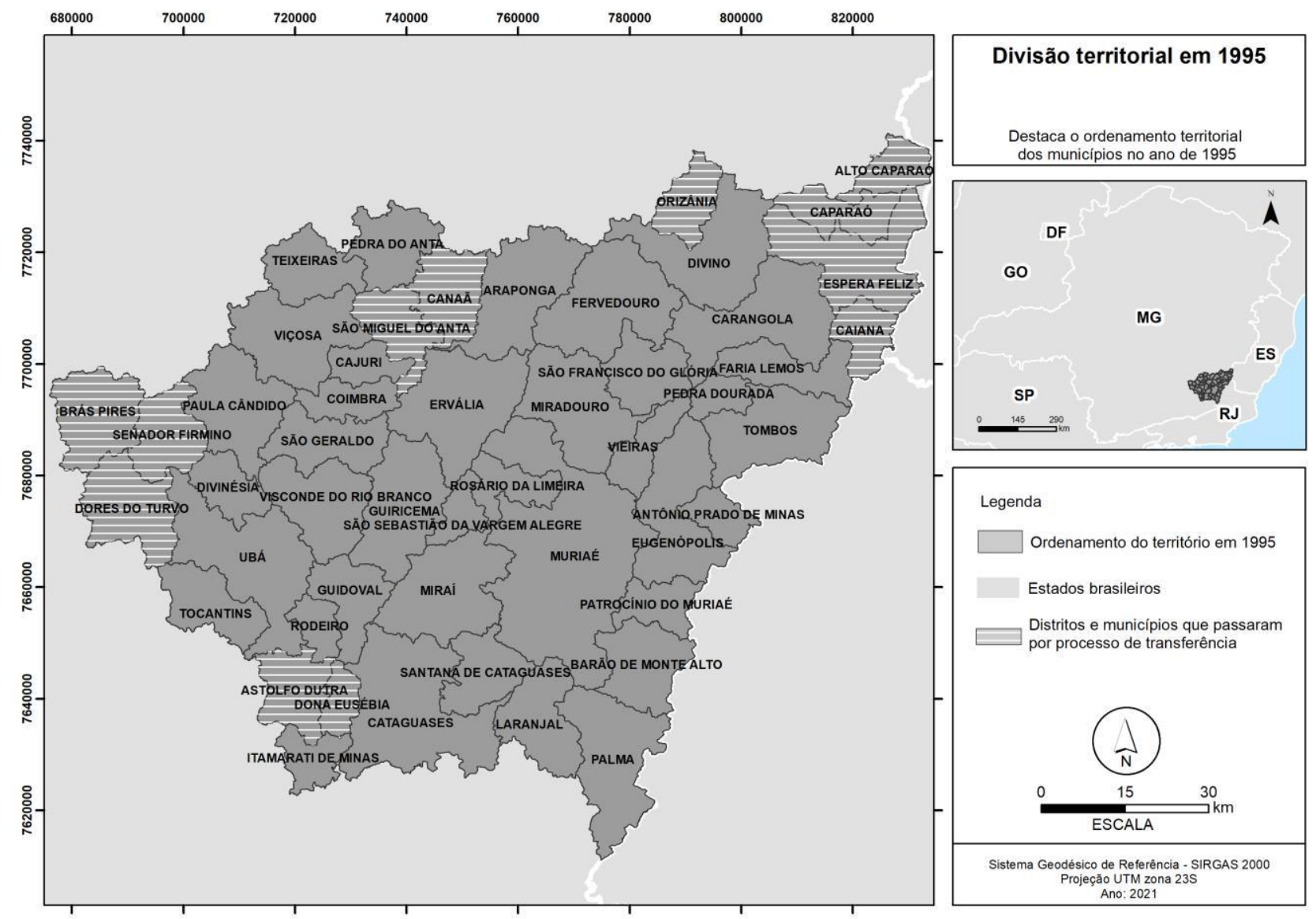

Fonte: Elaborado pelo autor (2021).

A divisão política-administrativa de 1995 demonstra a presença de quarenta e nove municípios, trata-se de divisão atual na área de estudo tendo em vista que após esse ano não ocorreram mudanças como a criação de um novo município ou até mesmo uma possível supressão. 
Através da divisão de 1995 verifica-se que alguns municípios estão grafados com linhas brancas, são eles: Dona Eusébia, Astolfo Dutra, Dores do Turvo, Senador Firmino, Brás Pires, São Miguel do Anta, Canaã, Espera Feliz, Caparaó, Alto Caparaó, Caiana e Orizânia. Esses municípios são os que em seu processo de origem foi constado que seus territórios não pertenciam a Vila de São João Batista do Presídio em 1839, porém em anos posteriores devido a criação e supressão de municípios eles passaram a ter vínculo com algum município que tem origem territorial com São João Batista do Presídio. O detalhamento da história evolutiva dos municípios específicos encontra-se no ítem 5.2.

O ordenamento anterior representado foi de 1961. Identifica-se número inferior de municípios se comparado com o ordenamento exposto em 1995. A escolha do período ocorreu propositalmente antes da publicação da Lei Estadual 2764 de 1962. A lei em questão instituiu os diversos pedidos de elevação de distritos a municípios de anos anteriores. Logo, a partir de 1962, diversos municípios foram emancipados.

O número de municípios antes da Lei Estadual de 2764 era de trinta e cinco para área. Entre as alterações foi possível constatar que ainda em 1961, Pedra do Anta era distrito de Teixeiras; Canãa era distrito de São Miguel do Anta; Caparaó, Alto Caparaó, Caiana pertenciam ao município de Espera Feliz; Orizânia era distrito de Divino; Fervedouro distrito do município de Carangola; Cajuri era distrito do município de Viçosa; Araponga era distrito de Ervália; Pedra Dourada era distrito de Tombos; Rosário da Limeira e Antônio Padro de Minas eram distritos de Muriaé; São Sebastião da Vargem Alegre era distrito de Miraí; Rodeiro e Divinésia eram distritos de Ubá; Dona Eusébia pertencia a Astolfo Dutra; Santana de Cataguases era distrito de Cataguases. 
Figura 12: Divisão territorial em 1961

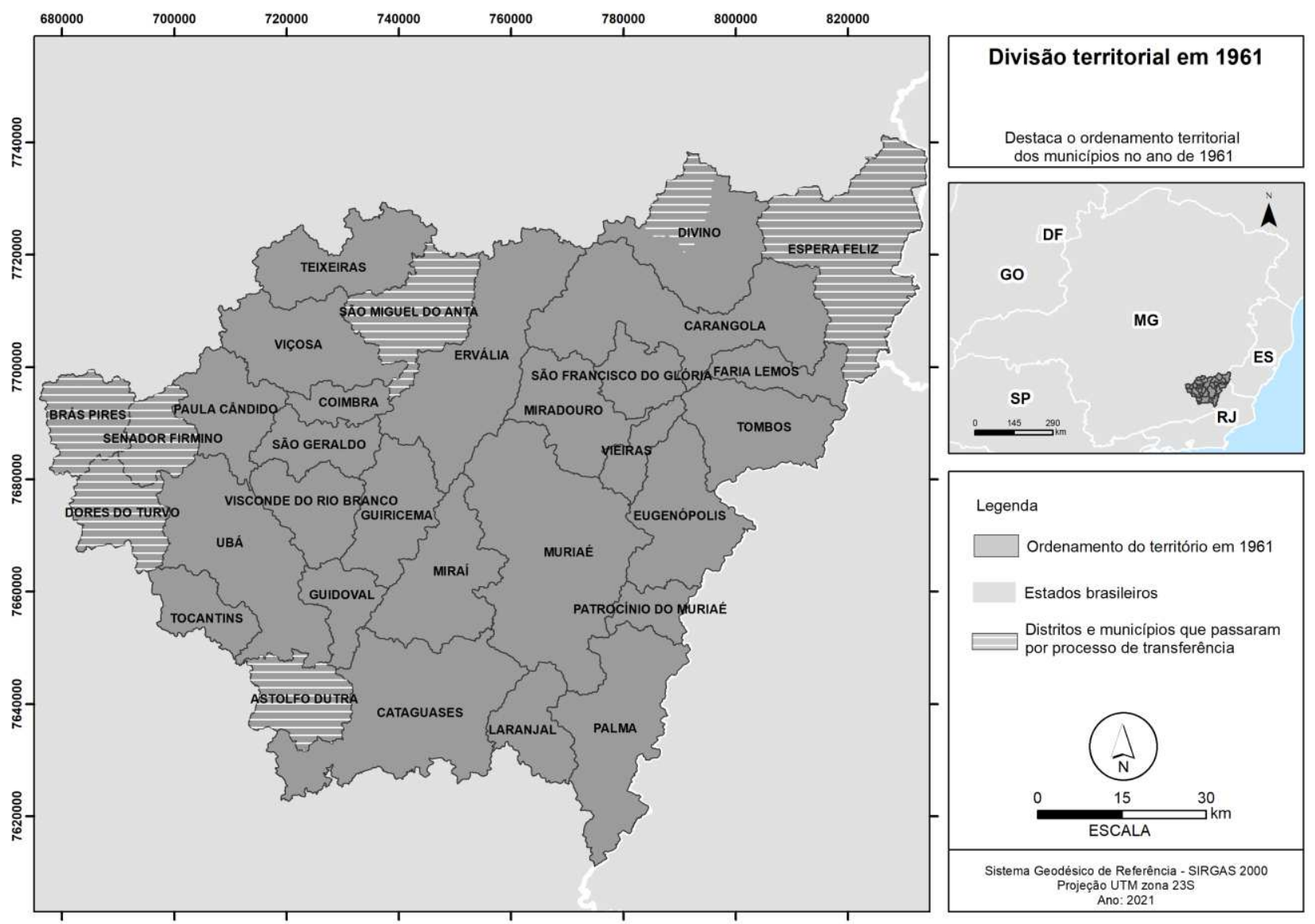

Fonte: Elaborado pelo autor (2021).

O período seguinte representado foi a organização do território dos municípios em 1941. De 1961 até 1941, as mudanças na configuração dos municípios ocorreram através da Lei $n^{\circ} 1039$, de 12 de dezembro de 1953 e da Lei estadual n 336 de 27 de dezembro de 1948. Ambas estabeleceram uma nova divisão administrativa do estado. Essas novas divisões significavam a criação de novos municípios, logo, em 1941, anteriormente a publicação das leis o número de municípios era de dezenove. Número consideravelmente inferior para um período de vinte anos entre a organização de 1961 e 1941. 
Figura 13: Divisão territorial em 1941;

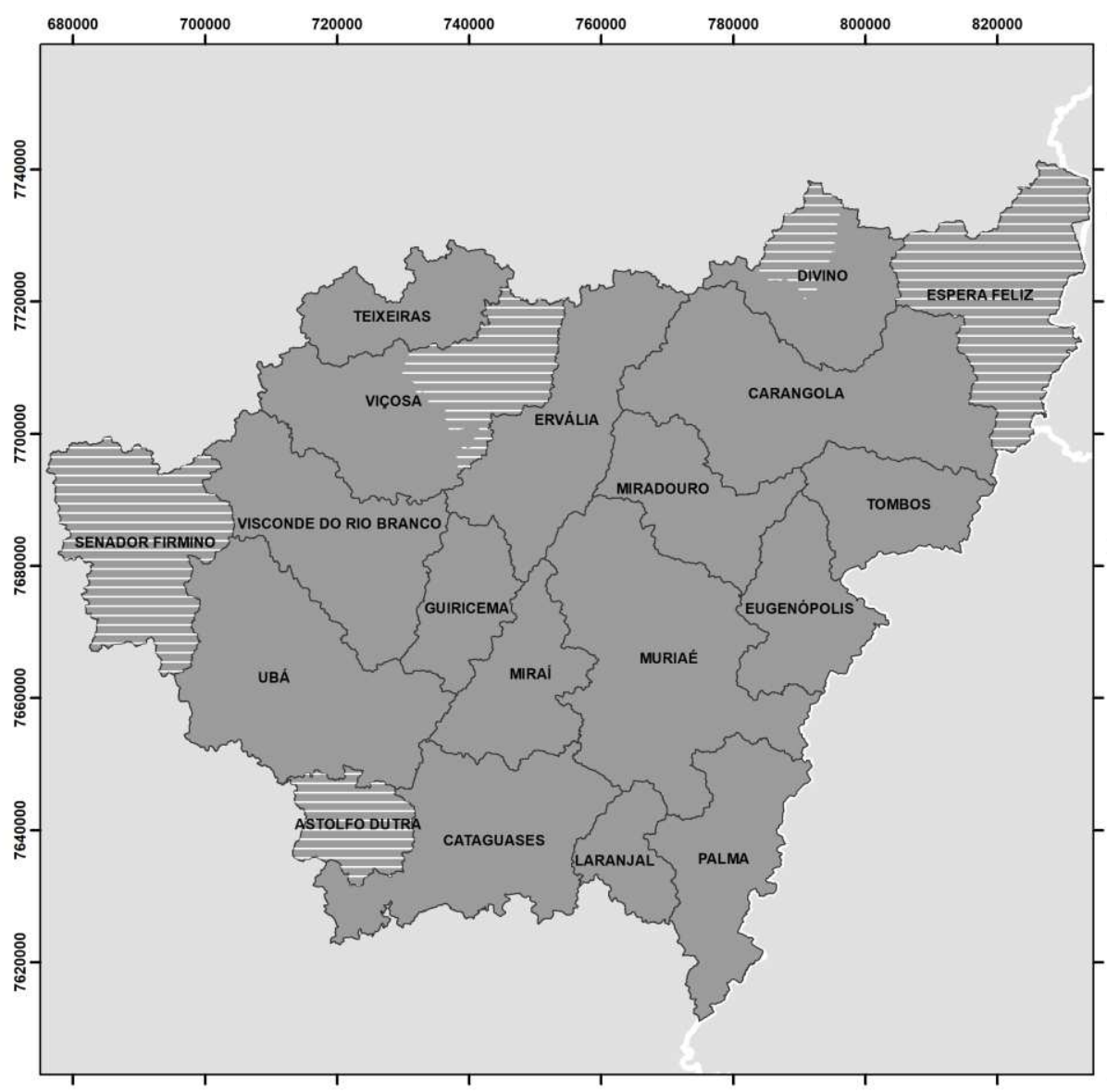

Divisão territorial em 1941

Destaca o ordenamento territorial dos municípios no ano de 1941
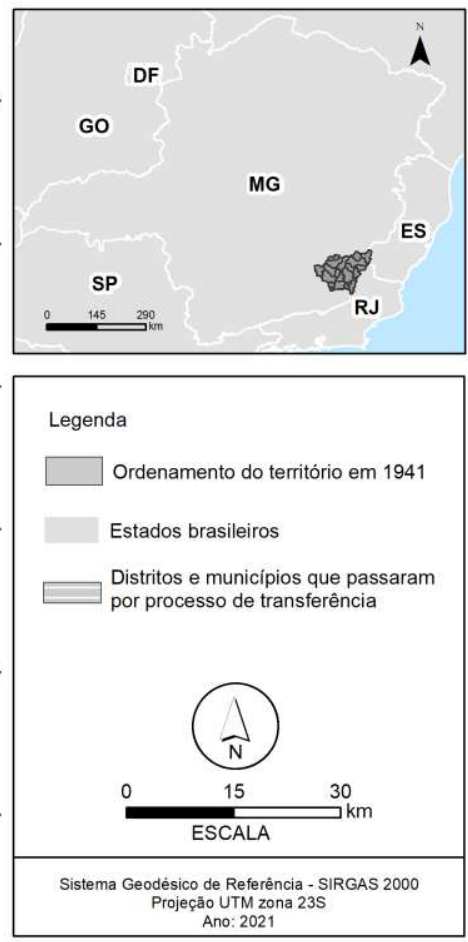

Fonte: Elaborado pelo autor (2021).

A partir da divisão político-administrativa de 1941 foi possível perceber que o território que atualmente compõe os municípios de Senador Firmino, Brás Pires e Dores do Turvo, em 1941 abrangia apenas o município de Senador Firmino. A elevação de Dores do Turvo e Brás Pires a município somente ocorreu em 1953. O território de Ubá apresentava uma grande extensão territorial, tendo em vista que neste período Guidoval e Tocantins se tratavam de distritos de Ubá. Ambos se elevaram a município apenas em 1948.

$\mathrm{Na}$ figura 8 da divisão político-administrativa identifica-se uma extensão maior de Visconde do Rio Branco e Viçosa. O primeiro tem como distrito São Geraldo e Paula Cândido, ambos emanciparam como município somente em 1948 e 1953, respectivamente. Já Viçosa a extensão de seu município era maior, tendo em vista que Coimbra e São Miguel do Anta compunham o seu território ainda como distritos. Ambos se elevaram a município somente em 1948 e 1953, respectivamente. 
Comparando as duas divisões, identifica-se também que os atuais municípios de Faria Lemos e São Francisco do Glória em 1941 compunham o município de Carangola. Ambos se elevaram a município somente em 1953. Percebe-se também que o atual município de Vieiras compunha em 1941 o município de Miradouro. 0 mesmo é válido para Patrocínio do Muriaé, em 1941 sua atual área compunha o município de Muriaé. Tanto Patrocínio do Muriaé como Vieiras, se elevaram a município somente em 1953.

A representação seguinte da divisão político-administrativa foi a de 1900. Para este período, a área conta com apenas oito municípios representados. Da representação anterior em 1941 para de 1900, o Decreto-lei nº 311 de 1938 foi o maior responsável pelas mudanças no ordenamento dos limites municipais entre os dois períodos. O decreto foi um marco na organização político-administrativa e territorial dos municípios em todo o Brasil. Este decreto também foi responsável pela elevação de diversos distritos a municípios a partir de 1938.

Entre as principais mudanças novamente estão a identificação dos atuais municípios que ainda eram distritos neste período. Miradouro por exemplo, representado como município anteriormente agora se situa na posição de distrito pertencente ao município de Muriaé. O mesmo é válido para Tombos, Divino e Espera Feliz. Ambos neste período são distritos do município de Carangola, enquanto o primeiro viraria município apenas em 1923, Divino e Espera Feliz se emanciparam somente em 1938. Portanto ambos compunham o limite territorial de Carangola. 
Figura 14: Divisão territorial em 1900

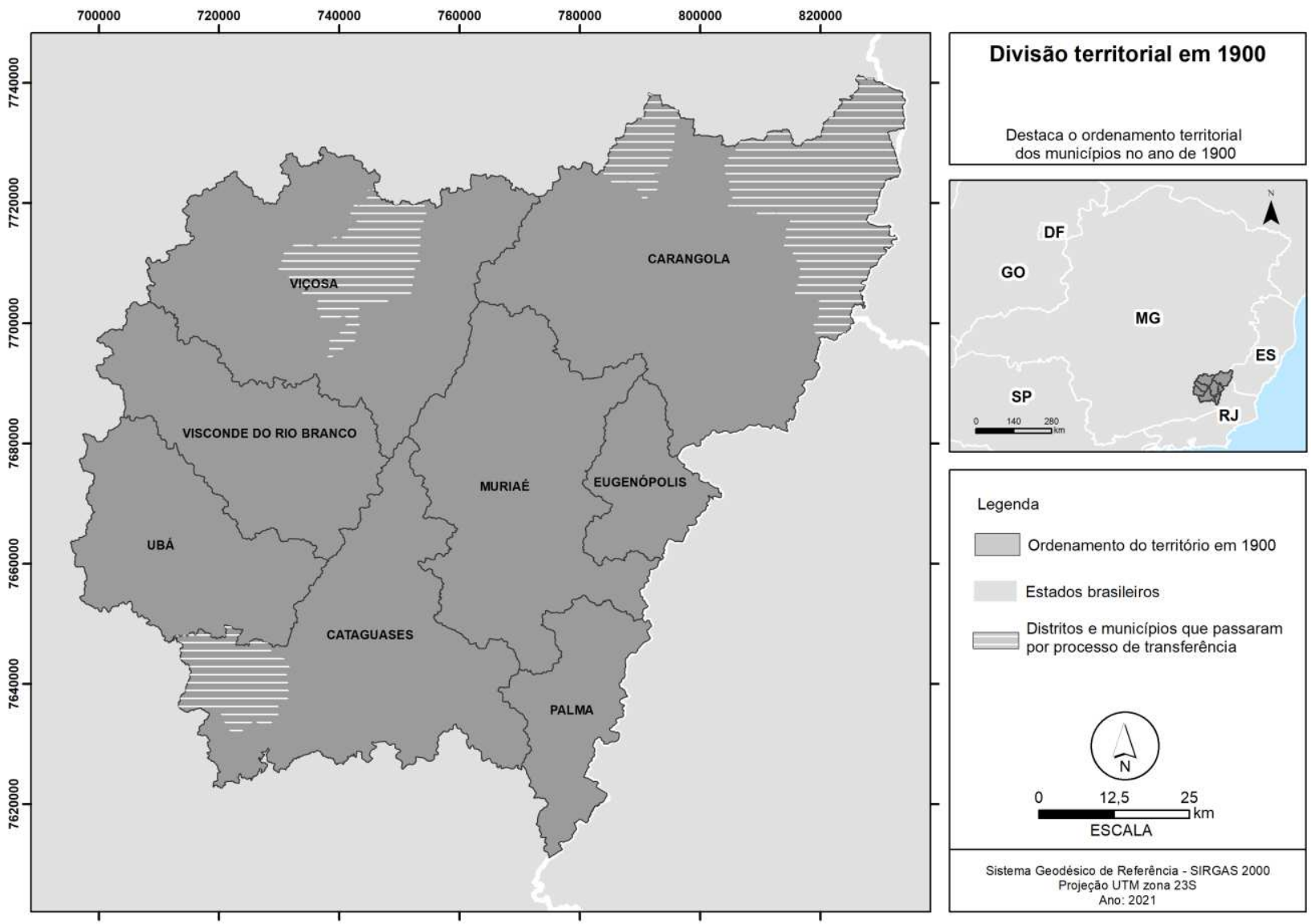

Fonte: Elaborado pelo autor (2021).

Na representação de 1900, identifica-se também que não existia o município de Astolfo Dutra, suas terras atuais representavam no período em questão o município de Cataguases. Neste período, o atual município de Laranjal compunha o território de Cataguases, como distrito. O distrito de Laranjal passou por um processo de transferência. Em 1875 suas terras pertenciam ao município de Cataguases, porém em 1890, segundo o Decreto estadual 297, de 23 de dezembro de 1890 estabeleceu que: "Ao novo município ficam pertencendo a freguesia de Nossa Senhora da Conceição do Laranjal". O novo município era justamente Palma, elevado a tal pelo artigo primeiro da mesma lei. E no ano seguinte, em 1891 através do Decreto 374, foi determinado que fica pertencendo a Cataguases a freguesia de Nossa Senhora da Conceição do Laranjal.

Identifica-se também que Teixeiras e Ervália, em 1900, compunham o território do município de Viçosa. Ambos eram distritos do município de Viçosa neste período. 
Já o município de Guiricema, representado na divisão anterior, compõe o município de Visconde do Rio Branco em 1900, como distrito.

O outro ponto se refere ao fato do município de Miraí (conferir divisão anterior) se apresentar na divisão de 1900 como parte do município de Cataguases. Segundo a Lei 2180 de 25 de novembro de 1875, o então distrito de Santo Antônio do Muriaé (Miraí) foi incorporado ao município de Cataguases, e permaneceu assim até 1923.

Por fim, comparando a divisão-política administrativa entre os períodos nota-se a ausência da área que se remete ao município de Senador Firmino na divisão de 1900. A retirada desta área ocorreu pois Senador Firmino quando ainda distrito, teve suas terras ligadas ao município de Piranga, até o ano de 1923, quando através da lei estadual 843, o distrito de Conceição do Turvo (Senador Firmino) foi transferido então para o município de Ubá. Logo, por ter se elevado a município desmembrando-se de Ubá, em um primeiro momento pode-se concluir que suas terras já pertenceram ao município de Presídio, o que não se confirma quando analisada a história de formação do seu município.

O prosseguimento da involução política-administrativa em direção ao território do município do Presídio tem como próxima representação a divisão no ano de 1872. Agora não mais sobre o regime republicano, identifica-se um número reduzido de municípios, consequência dos prematuros núcleos de formação urbana para a região no século XIX.

A divisão de 1872 apresenta-se apenas três municípios: Ubá, Viçosa e Muriaé. Inicialmente, esclarece que neste período Visconde do Rio Branco se tratava de distrito, consequência do processo de supressão de sua sede e elevação de Ubá como sede do município. Como a representação foi realizada em 1872, a lei $n^{\circ} 1755$, de 30 de março de 1871, declara em vigor a lei $n^{\circ} 654$, esta lei transfere a sede municipal para Ubá. 
Figura 15: Divisão territorial em 1872

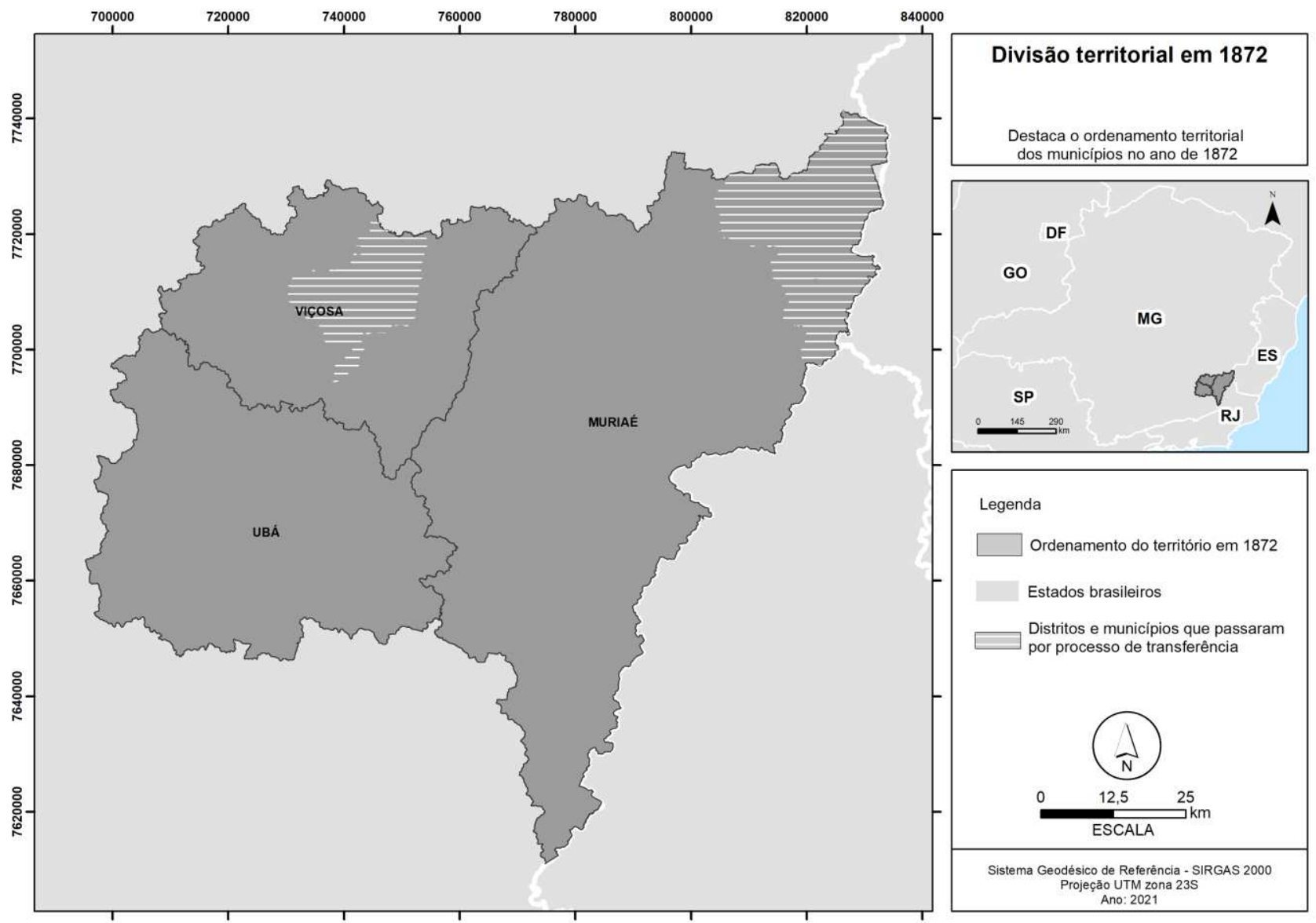

Fonte: Elaborado pelo autor (2021).

A partir da divisão de 1872 observa-se que comparado com a divisão de 1900 Viçosa apresenta a mesma configuração territorial. Porém já Carangola e Eugenópolis pertenciam ao município de Muriaé. Já que só se emanciparam como município em 1878 e 1892, respectivamente.

A área referente ao atual município de Orizânia (olhar divisão de 1995) não se ecnontra na divisão de 1872 . Sua retirada se deu a partir da identificação de que somente em 1891 o distrito foi transferido para Carangola através da Lei Estadual ${ }^{\circ}$ 391. Anteriormente o distrito pertencia ao município de Manhuaçu.

A área referente ao atual município de Astolfo Dutra (figura 11) não se encontra na divisão de 1872. Sua retirada se deu a partir da identificação de que somente em 1888 o distrito foi transferido para Cataguases de acordo com a Lei provincial 3589 de 28 agosto. Anteriormente o distrito de Porto de Santo Antônio (Astolfo Dutra), 
pertencia a Pomba. Por esse motivo sua área somente aparece nas divisões políticoadministrativas posteriores a essa data

A área referente ao atual município de Laranjal (figura 11) também não se encontra na divisão de 1872. Na divisão anterior de 1900 foi demonstrado no mapa e especificado no texto que o distrito de Laranjal naquele período pertencia ao recém criado município de Palma, tendo suas terras transferidas de Cataguases para Palma em 1890. Porém para o ano de 1872, o distrito de Laranjal pertencia a Leopoldina. $O$ distrito foi anexado ao município de Leopoldina através da Lei provincial $n^{\circ} 666$ de 1854, permanecendo como território de Leopoldina até 1875, quando transferido para Cataguases.

A área referente ao atual município de Palma (figura 11), foi anexada ao município de Muriaé. O distrito de São Francisco do Assis do Capivara (Palma) neste período fazia parte do município do Muriaé, tendo em vista que através da Lei provincial $n^{\circ} 1847$ de 1871 , o distrito foi transferido para Muriaé.

A área referente ao município de Cataguases (figura 11), não se encontra na divisão referente ao ano de 1872. Neste período Cataguases, ainda distrito, denominado Santa Rita de Meia Pataca pertencia a Leopoldina. Sua incorporação ao município de Leopoldina ocorreu através da Lei provincial nº66 de 1854.

$\mathrm{Na}$ análise do território de Ubá na representação em 1872, fica claro que suas terras foram representadas a partir da união dos territórios de Ubá, Visconde do Rio Branco e Miraí. O território de Visconde do Rio Branco foi anexado ao de Ubá pelo fato do processo de supressão de sua sede naquele período. Já o território do atual município Miraí foi anexado a Ubá pelo fato de que segundo a Lei provincial $\mathrm{n}^{\circ} 1847$ de 12 de outubro de 1871 o distrito de Santo Antônio do Muriaé fica transferido para o município de Ubá. Posteriormente o distrito foi transferido para Cataguases. Mas essa transferência somente ocorreu em 1875.

Por fim, a última divisão política-administrativa data 1839, ano em que a vila de São João Batista atual Visconde do Rio Branco foi elevada a vila, desmembrando-se de Pomba. O processo de involução adotado neste capítulo, buscou justamente adotar uma metodologia que fosse possível representar aproximadamente a extensão do território do município da Vila de São João Batista do Presídio em 1839. 
Figura 16: Divisão territorial em 1839

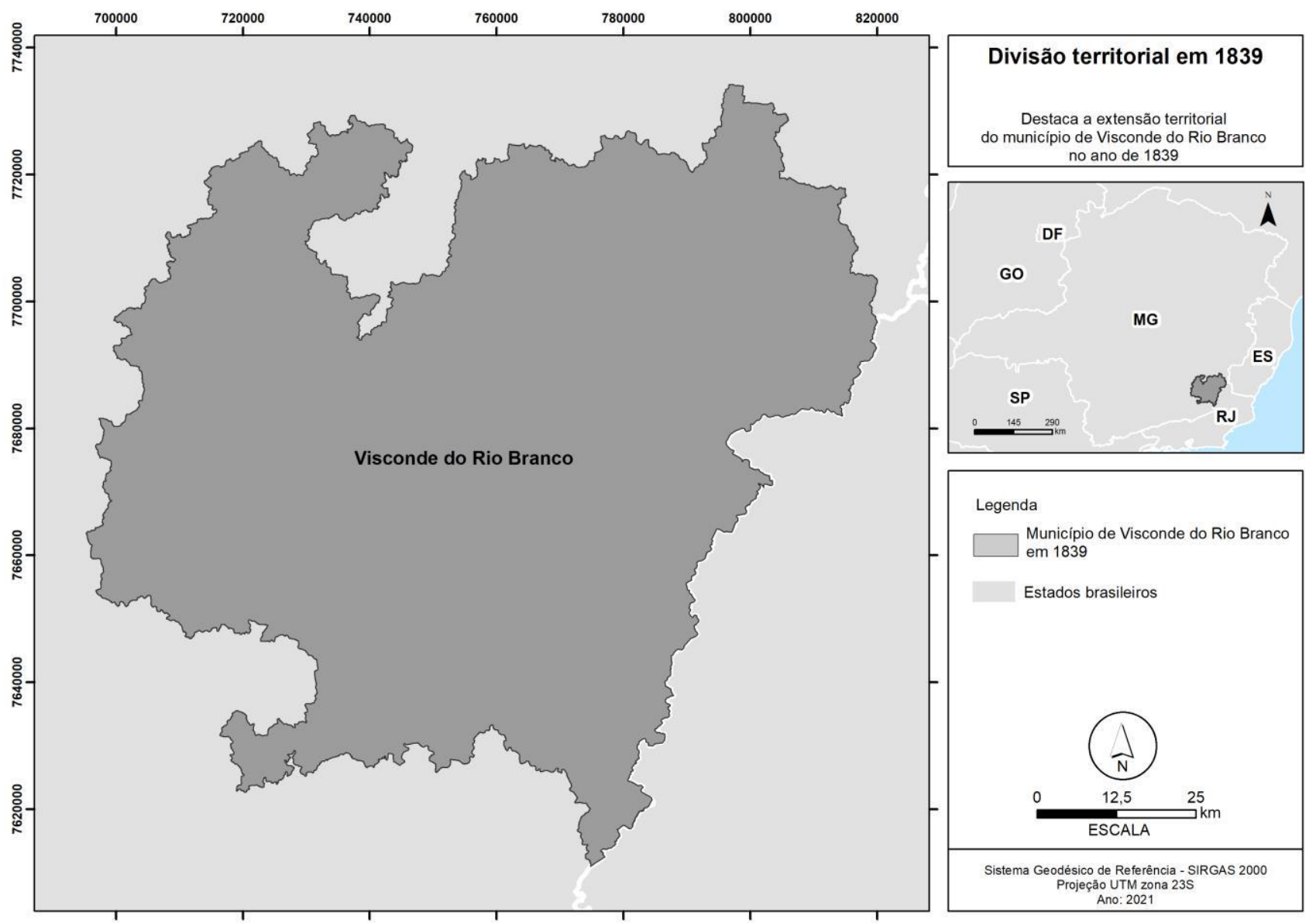

Fonte: Elaborado pelo autor (2021).

Inicialmente, destaca-se que o município da Vila de São João Batista do Presídio em 1839 era composto pelos distritos de Ubá, Muriaé e Viçosa. Se comparado com a divisão de 1995 (atual), pode-se considerar que trinta e sete municípios atualmente já pertenceram ao município de São João Batista do Presídio. Já desconsiderando os municípios que a partir do aprofundamento de sua história de formação foi constatado que suas terras não pertenceram a Presídio em 1839.

Da divisão de 1872 para a de 1839, percebe-se a ausência de Ubá, Muriaé e Viçosa, que nesse período pertenciam ao município do Presídio. Outro ponto passível de identificação, é a ausência de um trecho na região norte, que estava presente na divisão de 1872 dentro do limite do município de Viçosa. O trecho retirado, atualmente se refere aos municípios de Canaã e São Miguel do Anta (olhar divisão de 1995). Esse território, ao aprofundar na história de formação dos distritos de Canaã e São Miguel do Anta, pertencia ao município de Ponte Nova neste período. A área foi transferida 
para Viçosa quando este foi elevado a vila, somente em 1871, como detalhado na página 43.

Outro trecho também retirado da divisão faz referência atualmente aos municípios de Alto Caparaó, Caparaó, Espera feliz e Caiana. A área foi retirada pois pertencia a Vila de Campos, da província do Rio de Janeiro, como esclarecido na página 61.

Por outro lado, percebe-se que aumentou a extensão territorial na região sul. A área adicionada, atualmente se refere aos municípios de Laranjal e Cataguases. Laranjal, segundo a divisão anterior pertencia ao município de Leopoldina. Porém essa transferência foi realizada em 1854, e retomando um pouco mais, identifica-se através da Lei provincial $n^{\circ} 533$ de 10 de outubro de 1851, que o distrito de Laranjal foi transferido de Presídio para Mar de Espanha, comprovando assim que anteriormente seu território estava ligado a Presídio.

Já a área referente ao atual município de Cataguases, segue o mesmo contexto anterior. O distrito de Santa Rita de Meia Pataca (Cataguases) foi transferido para Leopoldina em 1854, porém a Lei provincial $n^{\circ} 533$ de 10 de outubro de 1851, define os limites do distrito que perpassavam pelo município de Presídio e Pomba, comprovando que antes de sua transferência para Leopoldina, pertencia a Presídio, como detalhado na página 51 .

Por fim, a representação da divisão política-administrativa de 1839 representa objetivo central de compreender a extensão territorial do Presídio, quando este foi elevado a município. Percebe-se também que diversas áreas foram transferidas para outros municípios e posteriormente voltaram a pertencer a Presídio, como foi o caso de Laranjal e Cataguases, antes de se elevarem a município. Todos esses distritos que passaram por processo de transferência pertenceram ao território do Presídio em 1839, as únicas exceções são aquelas que foram destacados nos mapas e citados no texto.

\subsection{Comparando a divisão realizada neste trabalho com a divisão realizada pelo IBGE (Instituto Brasileiro de Geografia e Estatística)}

A construção da involução territorial realizada neste capítulo, como informado na matriz metodológica, por considerar as informações obtidas através das leis 
provinciais e estaduais determinou divisões municipais pretéritas que se diferenciaram das realizadas pelo IBGE.

A metodologia utilizada pelo Instituto Brasileiro de Geografia e Estatística para a construção dos limites municipais pretéritos adotou como referência apenas a divisão municipal mais recente. Partir da divisão municipal mais recente é desconsiderar os processos de transferência de territórios que ocorriam com frequência no desenvolvimento territorial dos municípios. Diante dessa perspectiva, optou-se por comparar a evolução territorial deste trabalho com a realizada pelo IBGE.

O IBGE contém a evolução da divisão territorial para todos os anos que foram realizados recenseamentos, além dos anos de 1910 e 1930 que mesmo sem o recenseamento realizou-se a divisão territorial visando preservar a periodicidade dos levantamentos.

A efeito de comparação, adotou-se duas divisões realizadas pelo IBGE de períodos distintos, 1872 e 1900. São as duas divisões municipais mais antigas elaboradas pelo instituto. A comparação da divisão em 1900, apresenta diferenças menos significativas com a comparação realizada para o período de 1872. Isso ocorre pelo fato da metodologia do IBGE considerar a última alteração apenas antes da criação do município. Logo, a comparação para períodos mais antigos apresenta maiores diferenças. Para os períodos mais recentes, as divisões tendem a se igualar. A partir dessa perspectiva, caso houvesse divisão política do IBGE anterior a 1872 para uma possível comparação, maiores seriam as diferenças nas demarcações.

A divisão do IBGE considera como parte do município de Ubá em 1900 o território que atualmente se refere aos municípios de Senador Firmino, Brás Pires e Dores do Turvo. Esses municípios foram emancipados somente em 1938 e 1953, respectivamente. Logo, para responder a que município suas terras pertenciam anteriormente, foi necessário analisar informações quando eles ainda eram distritos.

O distrito de Conceição do Turvo (Senador Firmino), foi criado em 1865, pertencendo a Mariana. Posteriormente o distrito foi transferido para o município do Piranga em 1868, na qual permaneceu como parte do território de Piranga até o ano de 1923, quando foi transferido para Ubá.

O distrito de Dores do Turvo foi criado em 1850, pertencendo a Piranga. Em 1892 foi transferido para o município Alto do Rio Doce. E por fim, em 1938 foi 
transferido para o município de Senador Firmino, quando no mesmo ano foi criado o município de Senador Firmino.

O distrito de Brás Pires também pertenceu ao município de Piranga. Suas terras foram transferidas para Senador Firmino somente em 1938. Logo, através da história dos distritos foi possível identificar que em 1900 o distrito de Senador Firmino e Brás Pires pertenciam a Piranga, enquanto Dores do Turvo pertencia ao município do Alto do Rio Doce.

O fato da demarcação do IBGE apresentar o território dos três distritos como pertencentes ao município de Ubá se deve ao fato da metodologia considerar apenas a alteração mais recente. Logo, pelo fato do distrito de Senador Firmino ter se emancipado do município de Ubá, parte do pressuposto que suas terras sempre pertenceram ao município de Ubá. Já Dores do Turvo e Brás Pires, antes de elevados a município pertenciam a Senador Firmino, portanto se faziam parte do município de Senador Firmino, antes de sua criação considera que faziam parte de Ubá.

$\mathrm{Na}$ divisa entre Muriaé e Eugenópolis, identifica-se uma diferença entre a demarcação do IBGE e a deste trabalho. A área que causa a diferença se refere atualmente ao município de Vieiras. O distrito de Vieiras foi criado já no ano de 1948, através de terras desmembradas de Miradouro. Miradouro ainda quando distrito seu território pertencia a Muriaé. Diante dessa concepção, considerou-se na divisão deste trabalho a área deste território como pertencendo a Muriaé, porém na divisão do IBGE a área foi representada pertencendo a Eugenópolis.

Por fim, a última distinção entre as divisões em 1900 (figura 17) ocorre na área onde atualmente encontra-se o município de Alto do Jequitibá. Na divisão do IBGE considera este território como pertencente ao município de Carangola. Porém a Lei 843 de 1923, estabelece em seu artigo quinto que fica criado o distrito "de Presidente Soares, com sede na povoação do Jequitibá, no município de Manhumirim". Na mesma lei, o artigo quarto, cria o município de Manhumirim, e estabelece que incorpora o território do então novo município "os distritos de Manhumirim, Dores do José Pedro e Presidente Soares (desmembrados do município de Manhuaçu)." Essa foi a última evidência legal encontrada referente ao distrito de Presidente Soares, e nela fica claro que essas terras antes de serem transferidas a Manhumirim pertenciam a Manhuaçu. Diante dessa ótica a representação deste trabalho não considera o território em questão dentro dos limites do município de Carangola. 
Figura 17: Comparação da divisão política legal com a divisão do IBGE de 1900

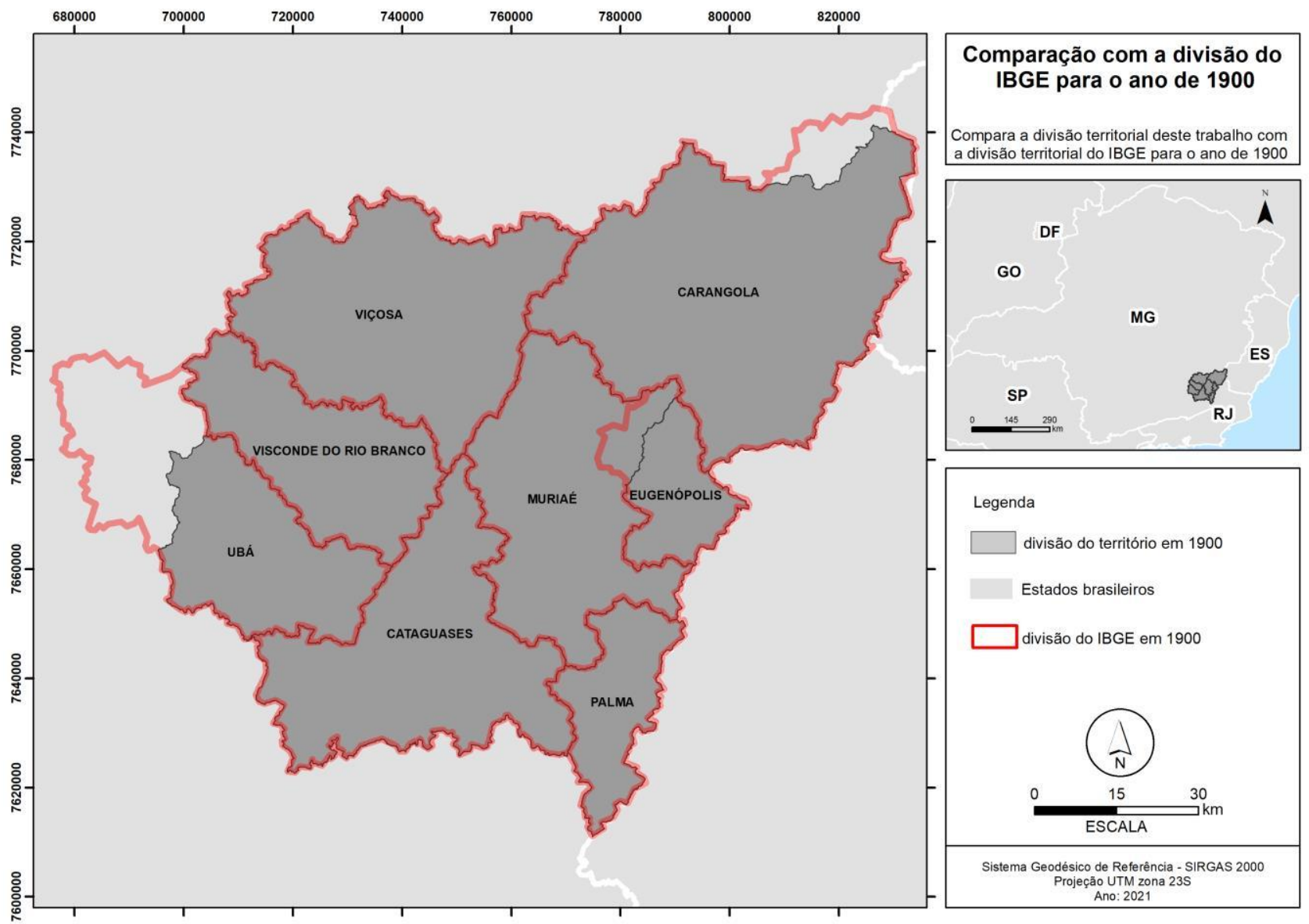

Fonte: Elaborado pelo autor (2021).

$\mathrm{Na}$ comparação entre as demarcações de 1872 (figura 13), ficou evidenciado, assim como na de 1900, que a área referente aos atuais municípios de Senador Firmino, Dores do Turvo e Brás Pires também foram consideradas pertences a Ubá. O que não se justifica pelos mesmos motivos elencados anteriormente. O mesmo é válido para o território que atualmente representa Alto Jequitibá, onde na divisão de 1872 do IBGE foi incluída como parte integrante do município de Muriaé. 
Figura 18: Comparação da divisão política legal com a divisão do IBGE de 1872

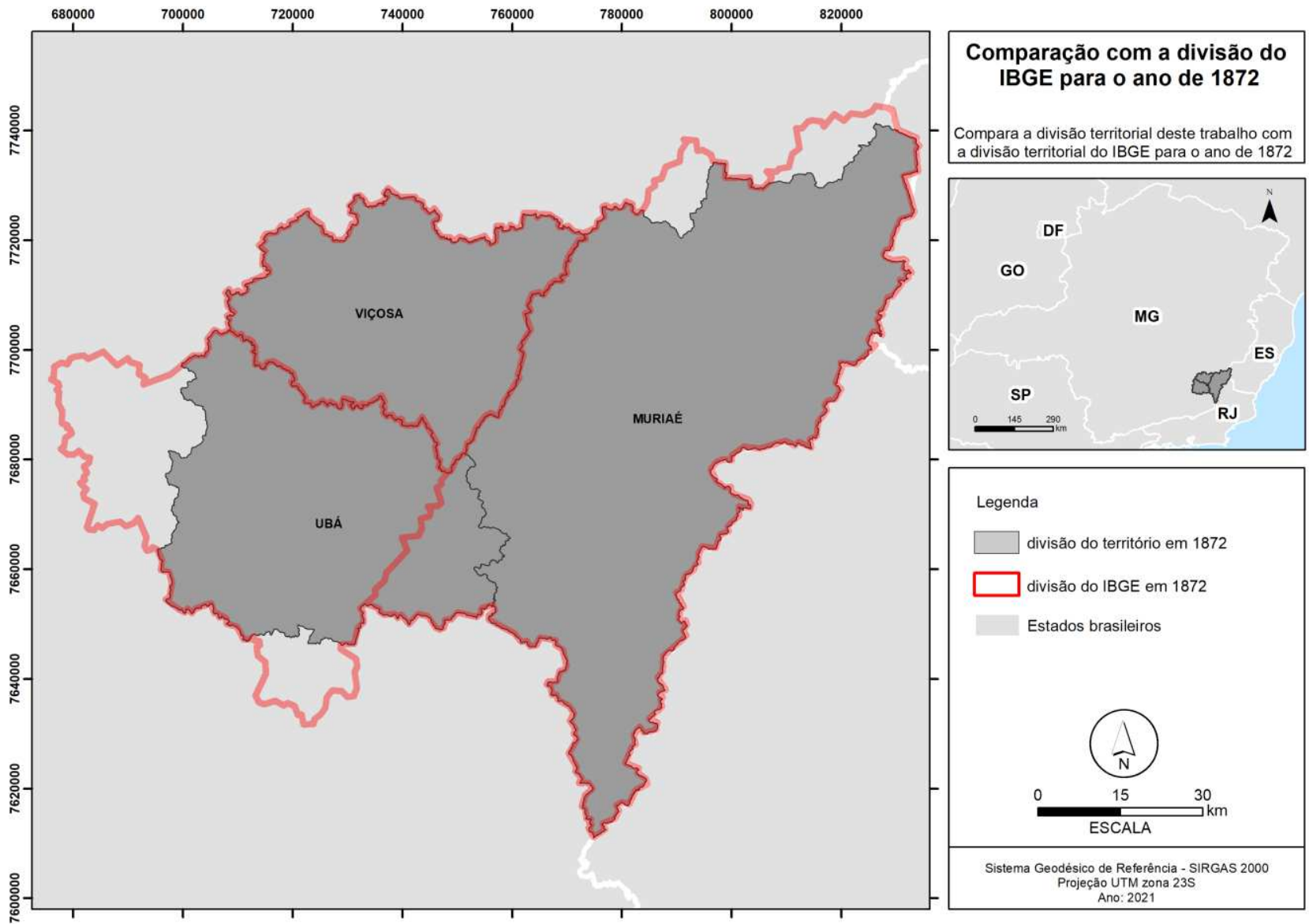

Fonte: Elaborado pelo autor (2021).

$\mathrm{Na}$ análise entre as divisões, identifica-se que a área do atual município de Orizânia, encontra-se pertencente a Muriaé na divisão do IBGE. A demarcação do IBGE ao incluir a atual área do município de Orizânia no limite de 1872, considera apenas a última mudança política-administrativa, que consiste no seu desmembramento de Carangola. Tendo em vista que Carangola desmembrou de Muriaé, a partir da metodologia do IBGE considera-se que esta área então sempre pertenceu a Muriaé. Porém uma análise a partir das leis provinciais, demonstra que esta área somente foi transferida para Carangola em 1891, anteriormente o território pertencia a Manhuaçu.

Na referência ao limite do município de Ubá em 1872, se constitui outra diferença entre as duas demarcações. A divisão do IBGE considera o território que atualmente pertence ao município de Astolfo Dutra e Dona Eusébia dentro do limite do município de Ubá em 1872. Porém, através da análise das leis provinciais, 
constatou-se que esses territórios pertenciam ao município de Pomba. E somente foram desvinculados de Pomba em 1888 através da lei provincial 3589 de 28 de agosto, como destacado na página 57 deste trabalho.

Por fim, a diferença entre os limites de Ubá e Muriaé são perceptíveis nas duas divisões. A diferença entre os limites ocorre justamente na área que se refere atualmente ao município de Miraí. Quando verificamos a história de formação de Miraí, identifica-se que o distrito foi criado em 1859, pertencendo ao município de Leopoldina. Em 1865, o distrito foi incorporado ao município de Muriaé. E já em 1871, através da Lei provincial 1847 de 12 de outubro, o distrito foi transferido para Ubá. Antes de ser elevado a município, as terras de Miraí ainda foram transferidas por uma última vez ao município de Cataguases em 1875. Diante dos processos de transferência, para o trabalho em questão considera-se que para o ano de 1872 aquelas terras pertenciam ao município de Ubá, causando diferenciação com a divisão do IBGE.

\section{CONSIDERAÇÕES FINAIS}

Diante dos resultados apresentados, destaca-se inicialmente que os estudos sobre o ordenamento político-administrativo e territorial dos municípios são complexos. Os estudos nesse campo envolvem diferentes áreas de pesquisas e ciências, exemplos são as pesquisas históricas, análise de mapas antigos e a leitura de diversas que foram necessárias para o desenvolvimento da pesquisa. A História, a Cartografia e o Direito estão presentes para um estudo Geográfico, na medida que se analisa a construção do território.

O estudo do ordenamento político-administrativo e territorial enfrenta uma grande dificuldade principalmente no que tange a abordagem dos limites territoriais anteriores a 1938. Como os municípios mineiros eram demarcados por propriedades rurais, e essas propriedades eram frequentemente transferidas entre um município e outro, demarcá-los precisamente se mostra uma tarefa impossível até 1938, quando os limites passaram a ser demarcados por paisagens naturais. Por essa questão o trabalho abordou a evolução dos limites territoriais na perspectiva da aproximação, assumindo que não se trata de uma delimitação precisa, e através da involução 
cartográfica (capítulo 5) e da análise do mapa antigo (capítulo 4) foi possível delimitar aproximadamente a extensão do território.

Em relação a constituição político-administrativa, destaca-se que o fato do poder eclesiástico estar presente ao longo do período colonial e imperial no ordenamento do território gerou ainda mais incongruência em estabelecer qualquer possibilidade de organização precisa. A dificuldade existente em traçar limites precisos para os municípios, somada a sobreposição do poder eclesiástico na divisão do território, e o fato dos limites das freguesias não serem claros, demonstram como o ordenamento territorial dos municípios mineiros eram confusos, assim como para o município do Presídio, inserido na mesma lógica. A análise da extensão territorial das freguesias que compunham o município do Presídio em 1847 corroborou com essa questão, incongruência na freguesia de São Januário de Ubá, em que seu território passava por outro município, e também a falta de conhecimento dos limites das freguesias pelos próprios párocos.

Se a demarcação territorial dos municípios e das freguesias foram tarefas que se mostraram impossíveis de se realizar com precisão, a análise das diferentes categorias administrativas, eclesiásticas e judiciárias ajudaram a compreender como ocorria o processo de desenvolvimento de um povoado até atingir a categoria de cidade. Visconde do Rio Branco em seu processo de desenvolvimento passou pelas diferentes categorias, em um processo comum aos municípios mineiros, o povoado evoluiu para arraial, posteriormente a capela curada, desse para freguesia, e em 1839 finalmente a criação do município e ao status de vila. A análise do processo evolutivo, e o grau de desenvolvimento de Visconde do Rio Branco através da análise do número da população e do número de fogos, demonstraram como a localidade apresentavase avançada em relação as demais localidades da zona da mata na porção central, o que lhe garantiu a categoria de município anteriormente as demais localidades, e consequentemente o seu município tem papel preponderante na territorialidade da porção central da zona da mata, tendo em vista que diversos municípios surgiram desmembrados do território de Visconde do Rio Branco.

Em relação ao mapa histórico utilizado, destaca-se a importância da cartografia histórica em pesquisas que adentram ao campo da geografia histórica. Os mapas históricos de uma maneira geral contam com diversas informações relevantes que contribuem para a pesquisa. Os mapas históricos foram criados sem auxílio da 
tecnologia atual, o que lhe confere distorções de posicionamento espacial, porém através do geoprocessamento, utilizando pontos de controle para georreferenciar o mapa, foi possível estabelecer um posicionamento adequado e utilizar suas informações. Os procedimentos metodológicos adotados podem ser utilizados em outras pesquisas no campo da geografia histórica e com outros mapas históricos, para isso é necessário encontrar pontos de mesma coordenada geográfica no mapa antigo e em um mapa atual georreferenciado.

O mapa e o relatório de João José da Silva Theodoro foram representativos para demonstrar como os limites dos municípios não eram claros e como a sobreposição de poder administrativo e eclesiástico dificultava a organização do território no século XIX. Silva Theodoro detalhou o seu trabalho de mapeamento, evidenciando que até mesmo para quem vivia naquele período e buscasse mapear o ordenamento territorial dos municípios encontraria dificuldade. Naquele período os limites dos municípios não eram claros, tanto que o mesmo foi contratado para solucionar o imbróglio dos limites daquele território com as províncias vizinhas. Silva relatou que em respeito às freguesias que compunham o território do Presídio, algumas delas o seu território não era conhecido pelo próprio pároco, como também os próprios moradores de determinados povoados não sabiam a qual freguesia pertenciam, evidenciando assim que a demarcação nunca foi clara, e quando se acrescenta o fator tempo, delimitá-las precisamente atualmente é ainda mais difícil.

No que diz respeito aos mapas temáticos produzidos através do mapa histórico (figura 8 e figura 9), foi possível observar novamente como o geoprocessamento pode ser um importante aliado da cartografia histórica uma vez que suas informações foram trabalhadas para se tornarem acessível ao leitor. Além disso o mapa vetorizado (figura 8) possibilitou representar como o espaço se organizava no século XIX, foi possível constatar a divisão do território em municípios com as suas sedes (vilas), e esses municípios subdivididos em freguesias, e essas freguesias compostas de outros curatos e capelas. Já a figura 9, representou a extensão territorial do município do Presídio e suas freguesias, sobrepostos a divisão municipal atual para demonstrar os atuais municípios que pertenciam à aquele território. Outra questão, é que o mapa histórico de 1847 foi a única fonte espacial do século XIX frente as fontes textuais, e quando o assunto é a organização do território e extensão territorial, a representação 
espacial ganha muita importância, logo o mapa do Theodoro permitiu representar o território ordenado de acordo com uma pessoa daquele período.

Em relação a involução cartográfica realizada (capítulo 5), os procedimentos metodológicos adotados foram eficazes em fornecer a divisão territorial dos municípios e em identificar a genealogia de cada município. Os procedimentos podem ser aplicados a qualquer área de estudo, sendo necessário partir da divisão atual e consultar todas as leis referentes as mudanças territoriais e administrativas. Os produtos cartográficos gerados a partir da involução cartográfica permitiram espacializar como foi o processo evolutivo da configuração territorial dos municípios da zona da mata na região central do ano de 1839 até a atualidade.

A involução cartográfica permitiu adotar procedimentos que são capazes de gerar uma divisão municipal mais detalhada do que a gerada pelo IBGE, os motivos já foram explicados no presente trabalho, porém a questão mais importante se refere a possibilidade de apresentar a divisão municipal para períodos anteriores a 1872.

Por fim o estudo sobre a organização político-administrativo e territorial é um tema ainda a ser aprofundado, o presente trabalho ao adotar Visconde do Rio Branco como área de estudo contribuiu com a história de construção e consolidação da territorialidade da porção central da zona da mata mineira. Espera-se que os resultados apresentados tenham concretizado os objetivos propostos no início da pesquisa. Embora a pesquisa tenha chegado a um produto final, ressalta-se a possibilidade de aperfeiçoar os procedimentos metodológicos e aplicá-los a outros municípios.

\section{REFERÊNCIAS}

ANAIS DO XIV SEMINÁRIO SOBRE A ECONOMIA MINEIRA, 14. 2010, Diamantina. GEOGRAFIA HISTÓRICA DA OCUPAÇÃO DA ZONA DA MATA MINEIRA: ACERCA DO MITO DAS "ÁREAS PROIBIDAS". Diamantina: Cedeplar, 2010. 25 p. Disponível em: https://diamantina.cedeplar.ufmg.br/portal/download/diamantina2010/D10A081.pdf. Acesso em: 24 abr. 2020.

ANDRADE, Manuel Correia de. A questão do território no Brasil. $2^{\mathrm{a}}$ edição. São Paulo: HUCITEC, 2004

ASSEMBLEIA LEGISLATIVA DO ESTADO DE MINAS GERAIS. Consulte: Legislação mineira. Belo Horizonte. Disponível em:

<http://www.almg.gov.br/consulte/legislacao/index.html/>. Acesso em: 10 maio 2020. 
BARBOSA, Yuri Amaral. PEQUENA GEOGRAFIA HISTÓRICA DE JUIZ DE FORA: O processo urbano do Caminho Novo ao inicio do século XX. Curitiba: Funalfa, 2017. 148 p.

BRASIL. Constituição da República dos Estados Unidos do Brasil: 24 de fevereiro de 1891. Câmara dos Deputados, Brasília. Disponível em: <http://www2.camara.leg.br/atividadelegislativa/legislacao/Constituicoes_Brasileiras/anteriores.html>. Acesso em: 5 mar. 2020.

BRASIL. Decreto $n^{\circ} 311$, de 1938. Dispõe sobre a divisão territorial do país e dá outras providências. Decreto-Lei $N^{\circ} 311$, de 2 de Março de 1938. Rio de Janeiro, p. 36-37.

Disponível em: http://www.planalto.gov.br/ccivil_03/decreto-lei/1937-1946/Del0311.htm. Acesso em: 10 ago. 2020.

BRASIL. Resolução n 21, de 24 de julho de 1810. Decisões: Resolução de Consulta da Mesa de Consciência e Ordens. Rio de Janeiro: Biblioteca da Comarca, Disponível em: https://www2.camara.leg.br/atividade-legislativa/legislacao/doimperio/colecao1.html. Acesso em: 15 abr. 2020.

BRASIL [Leis etc.]. Coleção de leis da República (1889-2000): inclui as leis, decretos e decisões desde o início do governo republicano. Brasília:Imprensa Nacional, 1890-2000. Digitalizado. Disponível em: <http://www2.camara.leg.br/atividade-legislativa/legislacao>. Acesso em: 10 fev.2020.

CARNEIRO FILHO, Raul. Jornalismo Literário - Livro reportagem: origens, transição e mercado. 2009. 140 f. Dissertação (Mestrado) - Curso de Comunicação Social, Universidade Presidente Antônio Carlos, Ubá, 2009.

CARNEIRO, Patrício AS et al. Geografia histórica da ocupação da zona da mata mineira: acerca do mito das "áreas proibidas". Anais do Seminário de Diamantina, 2010.

CARRARA, Angelo Alves; MACHADO, Pedro José de Oliveira. Delimitação territorial dos municípios brasileiros no século XIX: um desafio metodológico. Locus: Revista de História, Juiz de Fora, v. 25, n. 1, p.20-36, 2019.

CARRARA, Angelo Alves; MACHADO, Pedro José de Oliveira. ORDENAMENTO TERRITORIAL DOS MUNICÍPIOS BRASILEIROS: MINAS GERAIS, SÉCULOS XVIIIXIX. Almanack, Guarulhos, n. 24, ea03918, 2020 . Disponível em: $<$ http://www.scielo.br/scielo.php?script=sci_arttext\&pid=S2236-

46332020000100502\&Ing=en\&nrm=iso>. Acesso em: 08 mai. 2020.

CASTRO, J. F. M. Geoprocessamento de mapas de Minas Gerais nos séculos XVII-XIX. Belo Horizonte: Editora PUC Minas, 2017.

CASTRO, J. F. M. CARTOGRAFIA HISTÓRICA E GEOPROCESSAMENTO: O EXEMPLO DOS MAPAS DOS PADRES MATEMÁTICOS, DE 1734, E DO CÁLCULO DE RENDIMENTOS GERAIS DO BISPADO DE MARIANA, DE 1752. Revista do Departamento de Geografia - USP, São Paulo, Volume Especial Cartogeo, p. 123-140, 2014.

CHAVES, Edneila Rodrigues. The founding of villages in Minas Gerais in the beginning of the monarchy in Brazil: the North of the province. Varia Historia, v. 29, n. 51, p. 817-845, 2013.

CIGOLINI, Adilar Antonio. A fragmentação do território em unidades político administrativas: análise da criação de municípios no Estado do Paraná. 1999. 141 f. 
Dissertação (Mestrado) - Curso de Geografia, Universidade Federal de São Carlos, Florianópolis, 1999.

COLAVITE, A. P e BARROS, M. V. F. Geoprocessamento Aplicado a Estudos do Caminho de Peabiru. Revista da ANGEPE, v. 5, 2009. p. 86 - 105.

CORREAA, D. C. Cartografia Histórica do Rio de Janeiro: Reconstituição EspaçoTemporal do Centro da Cidade. Universidade Federal do Rio de Janeiro, Programa de Pós-Graduação em Geografia, Rio de Janeiro, 2008.

COSTA, Joaquim Ribeiro. Toponímia de Minas Gerais. Belo Horizonte: BDMG Cultural, 1997.

DUTENKEFER, Eduardo. Metodologia para um saber e um fazer geo-histórico: análise de espacialidades pretéritas utilizando instrumentos computacionais. Revista do Instituto de Estudos Brasileiros (rieb), São Paulo, v. 1, n. 65, p.55-71, 31 dez. 2016. Disponível em: <http://www.revistas.usp.br/rieb/article/view/125159>. Acesso em: 08 set. 2019.

ERTHAL, R. Geografia Histórica - Considerações. GEOgraphia, Ano V, n.9, 2003.

FERREIRA, J. Enciclopédia dos Municípios Brasileiros. Rio de Janeiro, 1959. v.27. Disponível em: https://biblioteca.ibge.gov.br/biblioteca-catalogo?id=227295\&view=detalhes Acesso em: 22 set. 2018.

FONSECA, Cláudia Damasceno. Arraiais e vilas d'el rei: espaço e poder nas Minas setecentistas. Tradução de Maria Juliana Gambogi Teixeira e Cláudia Damasceno Fonseca. Belo Horizonte: UFMG, 2011. 731 p. (Humanitas). Disponível em: < http://books.scielo.org/id/d55c7/pdf/fonseca 9788542303070.pdf>. Acesso em 01 de abr. 2020.

HAESBAERT, Rogério. Ordenamento territorial. In: Boletim Goiano de Geografia. v. 26, nº 01, janeiro/junho, 2006. p. 117-124

HAESBAERT, Rogerio. Território e multiterritorialidade: um debate. Geographia, Rio de Janeiro, v. 17, n. 9, p. 19-46, 2007. Disponível em:

https://periodicos.ufsm.br/geografia/article/view/22589. Acesso em: 01 jan. 2021.

IBGE, Recenseamento do Brazil em 1872, Rio de Janeiro: Typographia G. Leuzinger, s.d. [prov. 1875]. Disponível em: <https://biblioteca.ibge.gov.br/bibliotecacatalogo?id=225477\&view=detalhes>. Acesso em: 07 de ago. 2020.

JENNY, B. e HURNI, L. Studying cartographic heritage: Analysis and visualization of geometric distortions. Computers \& Graphics, 35-2, 2011. p. 402-411.

MACHADO, Pedro José de Oliveira. Diagnóstico ambiental e ordenamento territorial: instrumento para a gestão da Bacia de Contribuição da Represa de Chapeu D’uvas/MG. Niterói: UFF, 2012

MAGALHÃES, C. M. Na rota dos caminhos da estrada real e dos tropeiros. Cadernos de Pesquisa do CDHIS - n. 36/37, 2007. p. 111 - 117.

Mapa Índice Digital - MID: mapeamento geral do Brasil. 4a. ed. Rio de Janeiro: IBGE / DSG, 2011. 1 CD-ROM.

MARTINS, Lúcio Urbano Silva; SOARES, Rosane Vianna. Comarcas de Minas. Belo Horizonte: Imprensa Oficial de Minas Gerais, 2016. 
MARTINS, P. A. e SILVA, L. F. C. F. Panorama das Pesquisas com Sistemas de Informações Histórico-Geográficas no Mundo e Suas Relações com a Geografia, História e Cartografia Histórica. Revista Brasileira de Cartografia - n. 63/03, 2014. p. 485 - 498.

MARX, Murillo. CIDADE NO BRASIL TERRA DE QUEM? São Paulo: Editora da Universidade de São Paulo, 1991. 141 p.

MATA, Sérgio da. Chão de Deus: catolicismo popular, espaço e proto-urbanização em Minas Gerais, Brasil. Séculos XVIII-XIX. Berlim: Wiss. Verl. Berlin, 2002. 304 p.

MENEZES, P. M. L.; FERNANDES, M. C.; DIAS, A. C.; SANTOS, K. S.; NASCIMENTO, J. R. A evolução político-administrativa do estado do rio de janeiro. Acervo - Revista do Arquivo Nacional, v. 29, n. 1, p. 236-253, 2016. Disponível em: <http://hdl.handle.net/20.500.11959/brapci/44493>. Acesso em: 02 dez. 2019.

MINAS GERAIS. ASSEMBLÉIA LEGISLATIVA PROVINCIAL. Lei n 134, de 1839. ELEVA À VILAS AS POVOAÇÕES DO BONFIM, SANTA BÁRBARA, PRESÍDIO, CALDAS, OLIVEIRA E FORMIGA, ESTABELECENDO OS LIMITES DOS RESPECTIVOS MUNICÍPIOS, CRIA DUAS NOVAS CÂMARAS, SUPRIME O LUGAR DE JUIZ DO CIVIL DO TERMO DE SÃO JOÃO DEL-REI, E REGULA A NOMEAÇÃO DE JUÍZES DE DIREITO E SUBSTITUTOS, CONTENDO OUTRAS DISPOSIÇÕES COMO NELA SE DECLARA. Lei N. 134 de 16 de Março de 1839. OURO PRETO: Tipografia do Correio de Minas, p. 47-50.

MINAS GERAIS. ASSEMBLÉIA LEGISLATIVA PROVINCIAL. Lei n 654, de 1853. TRANSFERE A SEDE DOS MUNICÍPIOS DO PRESÍDIO, E JANUÁRIA, E DA FREGUESIA DE SÃO MIGUEL DO JEQUITINHONHA PARA OUTROS LUGARES, CRIA NOVAS FREGUESIAS E DISTRITOS, E CONTÉM OUTRAS DISPOSIÇÕES ACERCA DE LIMITES DE DIVERSAS PARÓQUIAS, E DISTRITOS, COMO NELA SE DECLARA. Lei N. 654 de 17 de Junho de 1853. Ouro Preto: Tipografia do Bom Senso, p. 167-170.

MINAS GERAIS. ASSEMBLÉIA LEGISLATIVA PROVINCIAL. Lei n 1573, de 1869. TRANSFERE A SEDE DO MUNICÍPIO DO UBÁ PARA A FREGUESIA DO PRESÍDIO. Lei N. 1.573 de 22 de Julho de 1868. Ouro Preto: Tipografia de J. F. de Paula Castro, p. 96.

MINAS GERAIS. ASSEMBLÉIA LEGISLATIVA PROVINCIAL. Lei n 1755, de 1871. MARCA DIVERSAS DIVISAS E CONTÉM OUTRAS DISPOSIÇÕES. Lei N. 1.755 de 30 de Março de 1871. Ouro Preto: Tipografia de J. F. de Paula Castro, p. 4-6.

MINAS GERAIS. ASSEMBLÉIA LEGISLATIVA PROVINCIAL. Lei n 2785 , de 1881. CRIA OS MUNICÍPIOS DE SANTANA DO BAMBUÍ, O DE SÃO JOÃO BATISTA DO PRESÍDIO E O DO ESPÍRITO SANTO DA VARGINHA. Lei N. 2.785 de 22 de Setembro de 1881. Ouro Preto: Tipografia de C. G. Andrade, p. 36-37.

MINAS GERAIS. Lei $\mathbf{n}$. 336, de 27 de dezembro de 1948. Coleção das Leis e Decretos de 1948. Belo Horizonte: Imprensa Oficial, 1950. v. I. p. 241-352.

MINAS GERAIS. Lei n. 1.039, de 12 de dezembro de 1953. Coleção das Leis de 1953. Belo Horizonte: Imprensa Oficial, 1961. p. 187-409.

MINAS GERAIS. LEI COMPLEMENTAR Nº 37/1995 de 18/01/1995. Disponível em: <https://leisestaduais.com.br/mg/lei-complementar-n-37-1995-minas-gerais-dispoe->

MINAS GERAES. Secretaria da Agricultura. Album Chorographico Municipal do Estado de Minas Geraes. Belo Horizonte, Imprensa Official. 1927 
OREA, Domingo Gómez. Ordenación Territorial. $2^{a}$ edição. Madrid: Ediciones MundiPrensa, 2008.

PIRES, Hindenburgo Francisco. Reflexões Sobre a Contribuição da geografia histórica e da geo-história na renovação dos pensamentos geográfico e histórico no século $X X$. I Colóquio Brasileiro de História do Pensamento Geográfico, Universidade Federal de Uberlândia, 2008.

PINTO, Theresinha de Almeida. Xopotó dos Coroados: cartilha. Visconde do Rio Branco: Imprensa Oficial de Minas Gerais, 2002. 40 p.

RAFFESTIN, Claude. Por uma geografia do poder. Ed. Ática. SP. 1993

REIS, E.; PIMENTEL, M.; ALVARENGA, A. I. Áreas mínimas comparáveis para os períodos intercensitários de 1872 a 2000 . Disponível em:

http://www.ipeadata.gov.br/doc/AMC-1872-2000.doc Acesso em: 20 set. 2018.

SEEMANN, Jörn. A TOPONÍMIA COMO CONSTRUÇÃO HISTÓRICO-CULTURAL: o exemplo dos municípios do estado do Ceará. Vivência, 1, n. 29, p.207-224, 2005.

Disponível em:

<https://s3.amazonaws.com/academia.edu.documents/3560594/vivencia_topo_JORN_SEE MANN.pdf?response-content

disposition=inline\%3B\%20filename\%3DA_TOPONIMIA_COMO_CONSTRUCAO_HISTORIC O-CU.pdf\&X-Amz-Algorithm=AWS4-HMAC-SHA256\&X-Amz-

Credential=AKIAIWOWYYGZ2Y53UL3A\%2F20200212\%2Fus-east-

$1 \% 2 F s 3 \% 2 F a w s 4$ request $\& X-A m z-D a t e=20200212 T 185605 Z \& X-A m z-E x p i r e s=3600 \& X-$

Amz-SignedHeaders=host\&X-Amz-

Signature $=21702 d c 61030367 c 375502 d 8 e 6294985 e 5 a f f 6711068 d 0211 \mathrm{c} 8 \mathrm{ca} 16634386885>$.

Acesso em: 12 fev. 2020.

TAVARES, Aparecida de Fátima. ENTRE O CAFÉ E O AÇÚCAR: PERFIL ECONÔMICO

DOS PRODUTORES DE VISCONDE DO RIO BRANCO (1870-1889) Juiz de Fora - Minas

Gerais 2013. 2013. 138 f. Dissertação (Mestrado) - Curso de História, Universidade Federal de Juiz de Fora, Juiz de Fora, 2013. Disponível em:

<http://www.ufjf.br/ppghistoria/files/2013/03/Aparecida-de-F\%C3\%A1tima-Tavares.pdf>.

Acesso em: 07 abr. 2020.

TAYLOR, D. R. F. A conceptual basis for cartography: new directions for the information era. The Cartographic Journal, London, v. 28, n. 2, p. 213-216, 1991.

THEODORO, João José da Silva. RELATÓRIO DO TENENTE JOÃO JOSÉ DA SILVA THEODORO. Ouro Preto: Typographia do Echo de Minas, 1847.

UMBELINO, G; CARVALHO, R e ANTUNES, A. USO DA CARTOGRAFIA HISTÓRICA E DO SIG PARA A RECONSTITUIÇÃO DOS CAMINHOS DA ESTRADA REAL. Revista Brasileira de Cartografia - n. 61/01, 2009. p. $63-70$.

\footnotetext{
$X$ - RELAÇÃO DAS CIDADES, VILLAS E POVOAÇÕES DA PROVINCIA DE MINAS GERAES COM DECLARAÇÃO DO NUMERO DE FOGO DE CADA UMA (1830). Ouro Preto: Imprensa Oficial de Minas Gerais, 1897. Disponível em:

http://www.siaapm.cultura.mg.gov.br/modules/rapm/brtacervo.php?cid=41. Acesso em: 02 dez. 2020.
}

ZAIDAN, R. T. GEOPROCESSAMENTO CONCEITOS E DEFINIÇÕES. Revista de Geografia - PPGEO - UFJF. Juiz de Fora, v. 7, n. 2, 2017, p. 195 - 201. 